\title{
INFLUÊNCIA DE BOCHECHOS COM SOLUÇÕES ANTIMICROBIANAS NA INIBIÇÃO DA PLACA DENTÁRIA E CONTAGEM DE ESTREPTOCOCOS MUTANS EM CRIANÇAS
}

\section{NILDICELI LEITE MELO ZANELA}

Tese apresentada à Faculdade de Odontologia de Bauru, da Universidade de São Paulo, como parte dos requisitos para obtenção do título de Doutor em Odontologia, área de Odontopediatria.

\section{BAURU}




\section{INFLUÊNCIA DE BOCHECHOS COM SOLUÇÕES ANTIMICROBIANAS NA INIBIÇÃO DA PLACA DENTÁRIA E CONTAGEM DE ESTREPTOCOCOS MUTANS EM CRIANÇAS}

\section{NILDICELI LEITE MELO ZANELA}

Tese apresentada à Faculdade de Odontologia de Bauru, da Universidade de São Paulo, como parte dos requisitos para obtenção do título de Doutor em Odontologia, área de Odontopediatria.

Orientadora: Profa Dra Maria Francisca Thereza Borro Bijella

\section{BAURU}


Zanela, Nildiceli Leite Melo

Z16i Influência de bochechos com soluções antimicrobianas na inibição da placa dentária, em crianças / Nildiceli Leite Melo Zanela. - Bauru, 1999.

168p. : il. ; $30 \mathrm{~cm}$.

Tese. (Doutorado) -- Faculdade de Odontologia de Bauru, USP.

Orientadora: Prof ${ }^{\mathrm{a}}$ Dr${ }^{\mathrm{a}}$ Maria Francisca Thereza Borro Bijella

Autorizo, exclusivamente para fins acadêmicos e científicos, a reprodução total ou parcial desta tese, por processos fotocopiadores e outros meios eletrônicos.

Assinatura do autor:

Bauru, 29 de outubro de 1999 


\section{DADOS CURRICULARES}

\section{NILDICELI LEITE MELO ZANELA}

26 de novembro de 1967 João Pessoa / PB

$1986-1989$

1992

1995

1999

Associações
Nascimento

Curso de Odontologia - Faculdade de Odontologia de Bauru da Universidade de São Paulo

Curso de Pós Graduação em Odontopediatria em nível de Mestrado na Faculdade de Odontologia de Bauru, U.S.P.

Curso de Pós Graduação em Odontopediatria em nível de Doutorado na Faculdade de Odontologia de Bauru, U.S.P.

- Professora Adjunta da UNIP Universidade Paulista, Campus Bauru

- Associação Paulista de Cirurgiões Dentistas - APCD.

- Sociedade Brasileira de Pesquisas Odontológicas -SBPqO. 


\title{
ȦDEU QUE ME ABEDÇOAE XE ACOMPAIXAR EMTODOS OS MIOMEATOS
}

\author{
"Feliz o bomem que acba sabedoria, e o bomem que
} adquire conbecimento; porque melbor é o lucro que ela dá do que a prata, e melbor a sua renda do que o ouro mais fino."

(Provébios 3:13-14) 


\section{Meu amor e agradecimento especial,}

Às minhas filbas Laura e Daniela, beranças do Senbor em minha vida,

Ao meu marido Sérgio, pelo toque especial de amor e atenção,

Alos meus pais, Onildo e Graceli, pelo exemplo de vida, dedicação e por acreditar em mim. Vocês são um alicerce em minha vida,

Alos meus queridos irmãos, Dil, Gundo e Omar, pela expressão de união e força nos momentos em que tudo parecia inatingínel,

"Sempre dou graças a Deus a vosso respeito..."

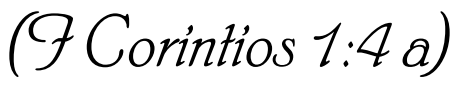

Com vocês, tenbo a certeza do infinito amor de Deus em minha vida! 


\section{$\grave{A}$ Prof Dr ${ }^{a}$ Maria Trancisca Thereza Borro Bijella,}

reforço o meu reconbecimento e carinbo por tudo que me ensinou, me dedicou e pelo meu crescimento profissional. 
$\grave{A} \operatorname{Prof}^{\circ} \mathcal{D}^{a}$. Odila, minba co-orientadora, em quem pude encontrar confiança, paciência e respeito.

Quero expressar a minha estima, gratidão e o meu reconbecimento. 


\section{Agradeço,}

Aos professores do Departamento de Odontopediatria pelo ensino e orientação,

Pos funcionários do Departamento de Odontopediatria, D. Lia, D. Wilma, Fátima, Paulo, Lilian e Estela pelo carinbo e atenção,

Ao Departamento de Bioquímica e ao Departamento de Odontologia Social pela colaboração na execução desse trabalbo,

Ao Prof. Dr. Eymar Sampaio Lopes, pela análise estatística,

भis estagiárias do Departamento de Odontopediatria: Daniela, Ana Carla, Bianca e Adriana, pela ajuda na parte experimental,

Aos colegas de Doutorado Bia, Cadu e Mlax, pelo companbeirismo,

ȦValéria, amiga especial, pela atenção em todos os momentos. 


\section{Minba sincera gratidão}

Ao Sr. Jilson, D. Toemi e às minbas cunbadas Elaine e Lola,

ஷ̀ minba tia Onilda pelas orações e pelo amor que tanto demonstra por mim.

A todos meus amigos que torcem por mim.

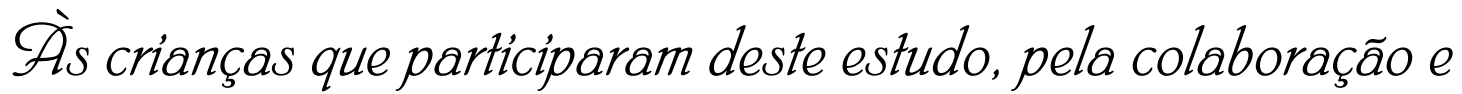
carinbo que me ofereceram e que fizeram valer todo meu esforço,

Aos Pais, Diretoras e Professores da Escola Rogacionista "Padre Paulo Petruzellis", e Escola Mlunicipal "Santa Maria" pela cooperação e empenbo os quais permitiram o desenoolvimento do trabalbo,

À Sara e esposo pelo carinbo a mim dispensado,

$\not{A}$ Vera, pela arte final que proporcionou a este trabalbo.

$\dot{A}$ Prof Ana Virgínia pelo capricho e atenção dados na revisão da Lingua Portuguesa. 


\section{SUMÁRIO}

RESUMO

1 - INTRODUÇÃO 1

2 - REVISÃO DE LITERATURA 7

2.1 - Clorexidina 8

2.2 - Clorexidina associada ao flúor 48

2.3 - Esteviosídeo $\quad 62$

3 - PROPOSIÇÃO

4 - MATERIAL E MÉTODOS 76

5 - RESULTADOS

5.1 - Análise Clínica $\quad 86$

5.2 - Análise Microbiológica 101

6 - DISCUSSÃO 108

6.1 - Análise Clínica 109

6.2 - Análise Microbiológica 131

7 - CONCLUSÕES 143

REFERÊNCIAS BIBLIOGRÁFICAS 146

$\begin{array}{ll}\text { ABSTRACT } & 165\end{array}$ 
RESUMO 


\section{RESUMO}

Avaliou-se, em crianças, o efeito de bochechos diários com solução placebo composta de água deionizada mentolada (Grupo I); gluconato de clorexidina 0,12\% associado ao fluoreto de sódio $0,05 \%$ (Grupo II); digluconato de clorexidina 0,2\% (Grupo III) e esteviosídeo 0,5\% associado ao fluoreto de sódio $0,05 \%$ pH 3,4 (Grupo IV), sobre a inibição do acúmulo de placa dentária e sobre o nível de estreptococos mutans salivar. Para a verificação do efeito sobre a placa, empregou-se o índice de LÖE e a contagem microbiana na saliva foi realizada através do CARITEST SM (Herpo - Produtos Dentários LTDA). A amostra constou de 200 crianças de 7 a 11 anos de idade, sendo 50 por grupo, nas quais avaliou-se o acúmulo de placa dentária no início e final do experimento. Dessas crianças, foram selecionadas 20 de cada grupo, ao acaso, para as coletas de saliva que foram executadas em 3 etapas: inicial (antes do primeiro bochecho), 24 horas após o primeiro bochecho e uma semana após o último bochecho. Em todos os grupos, as crianças receberam profilaxia profissional antes do início do experimento e seguiram o regime de bochechos diários, com $5 \mathrm{ml}$ de solução, por 1 minuto, durante 4 semanas. Os resultados mostraram uma inibição do acúmulo de placa de 2,89\%; $26,75 \% ; 41,20 \%$ e $5,91 \%$ para os grupos I, II, III e IV, respectivamente. Em relação às faces dentárias, os grupos II e III, mostraram maiores reduções percentuais para a face vestibular, vindo a seguir a proximal e lingual, sendo que no grupo II, não existiu diferença estatisticamente significante entre todas as faces e para o grupo III, essa diferença foi entre as faces lingual e mesial. Já no grupo IV, esse resultado foi maior para a face lingual, diferindo estatisticamente apenas da face distal. A solução de digluconato de clorexidina $0,2 \%$ registrou menor aceitação pelas crianças e, juntamente com a solução de gluconato de clorexidina $0,12 \%$ associada ao fluoreto de sódio $0,05 \%$, promoveu pigmentações dentárias suaves e semelhantes. Com relação à contagem de estreptococos mutans, devido as crianças apresentarem no início do experimento baixos valores desses 
microrganismos, os mesmos assim permaneceram, não existindo diferença estatisticamente significante entre as contagens. Concluiu-se que a solução de gluconato de clorexidina $0,12 \%$ associada ao fluoreto de sódio $0,05 \%$ e a solução de digluconato de clorexidina $0,2 \%$ foram no regime utilizado, as mais efetivas no controle do acúmulo de placa dentária, em crianças. Entretanto, a segunda registrou maior redução percentual e menor aceitação com relação ao sabor da solução. 
1 - INTRODUÇÃO 


\section{1 - INTRODUÇÃO}

A cárie dentária é uma doença infecciosa, multifatorial, estando presente numa proporção direta com a placa bacteriana ${ }^{33}$. A formação de placa dentária é um processo progressivo e dinâmico que pode resultar no estabelecimento da cárie e da gengivite. Assim, a base da higiene bucal é desestruturar regularmente a placa, no intuito de compatibilizar com a saúde bucal ${ }^{12}$.

As bactérias são componentes essenciais da placa e devese salientar que a microbiota bucal é bastante variada e das mais concentradas do corpo, estando integrada ao hospedeiro dentro de um equilíbrio de seus fatores de virulência e os diversos mecanismos de resistência local ${ }^{54}$.

Destacam-se como especificamente relacionados com a lesão coronária de cárie dentária os estreptococos do grupo mutans e os lactobacilos ${ }^{53,72}$. Os estreptococos mutans são microrganismos acidogênicos e acidúricos, relacionados com o início da lesão. Em virtude dessa associação, uma avaliação do número dessas bactérias na placa ou na saliva pode auxiliar no diagnóstico da atividade de cárie e também ser utilizada para estabelecer um padrão normal de colonização para um determinado paciente e avaliar o efeito de substâncias antimicrobianas ${ }^{14}$. Para a análise da quantidade desses microrganismos na cavidade bucal, podem ser empregados testes bacteriológicos, que se utilizam de amostras de saliva.

Dessa forma, para a prevenção da cárie dentária, é fundamental o controle da placa ${ }^{34}$. Na intenção de se auxiliar os meios de 
limpeza mecânica habitual exercida pelo paciente, têm-se empregado vários agentes químicos, visando suprir eventuais falhas no controle mecânico. Com isso, os agentes químicos poderiam atuar especificamente em situações nas quais o paciente apresente atividade de cárie, associando-se também o aconselhamento dietético.

Os agentes antimicrobianos são substâncias que podem reduzir a incidência de cárie dentária pelo controle da formação de placa, diminuindo as espécies cariogênicas ou inibindo o metabolismo bacteriano ${ }^{12}$, 28, 72 . Entretanto, quando utilizados isoladamente não promovem o controle completo da placa dentária.

A efiácia e o modo de ação das substâncias químicas têm sido estudados e revisados, sendo que a clorexidina tem apresentado resultados satisfatórios ${ }^{14,23,28,43,53,78}$. A clorexidina é uma biguanidina fortemente básica, contendo 2 cargas positivas, considerada um antiséptico seguro e efetivo na redução de placa, gengivite e de estreptococos mutans, tanto na placa quanto na saliva $14,28,34,35,78,89$.

A clorexidina, empregada principalmente na forma de solução de gluconato e digluconato de clorexidina, tem sido utilizada por uma variedade de meios, tanto para prevenção de cárie ${ }^{110}$ como controle de placa $21,31,60,61,64$. Desses métodos, pode-se citar soluções para bochechos na concentração $0,2 \%, 0,1 \%$ e $0,12 \%{ }^{2,3,21,26,61,64,81,109}$, géis a $1 \%$ e $5 \%{ }^{53,68,110}$, soluções para aplicação tópica a $2 \%{ }^{95}$, solução para irrigação nos espaços interdentais ${ }^{53,68}$, dentifrícios e sprays ${ }^{53}$ e ainda além disso vernizes ${ }^{53,68}$.

A forma de aplicação em bochechos foi considerada mais fácil $^{8}$, simples ${ }^{89}$ e a freqüência diária tem-se mostrado efetiva ${ }^{61,65,109}$. Sua ação imediata é de forma bactericida, durante o tempo de aplicação na 
cavidade bucal, quando uma substancial quantidade de bactérias é morta ${ }^{46}$, porém, não é suficiente para prevenir a formação de placa ${ }^{35}$. Apesar disso, uma das propriedades da clorexidina, a substantividade, pode manter um efeito bacteriostático prolongado como resultado de sua adsorsão na película adquirida, na superfície do esmalte e na saliva ${ }^{46,60}$. Assim os microrganismos não se multiplicam, pois a atividade metabólica é fortemente inibida, provavelmente na habilidade de produzir substâncias de adesão e assim manter um efeito sobre a formação de placa $^{35}$.

Segundo TONELLI; HUME; KENNEY ${ }^{102}$, a efetividade da clorexidina está em prevenir a formação inicial de placa e em desorganizar a que já está formada, promovendo sua utilização em várias situações clínicas onde há a necessidade de cuidados especiais no controle da placa dentária.

Diversos trabalhos são encontrados na literatura através dos quais puderam-se analisar a da eficácia dessa substância através do índice de placa $2,3,4,6,16,18,21,60,61,64,65,95,102,109$, do seu mecanismo de ação inibitória ${ }^{16,18}$, dos efeitos colaterais ${ }^{2,3,4,6,16,21,61,109}$ e de sua ação antimicrobiana 4,19,50,63,87,110. Entretanto, apesar de seu emprego como agente antiplaca e, conseqüentemente, como agente anticariogênico ser de grande importância para a Odontologia, poucos são os trabalhos desenvolvidos em crianças ${ }^{32,68,70,95,109,110}$.

Com o intuito de se melhorar os efeitos da clorexidina sobre os estreptococos mutans, placa e cárie dentária, a combinação dessa substância antimicrobiana com o flúor tem sido estudada. Trabalhos clínicos ${ }^{49,70,99}$ e "in vitro" ${ }^{\prime \prime 6,67,69,71}$ têm mostrado que a associação com o flúor é particularmente efetiva contra estreptococos 
mutans, parecendo haver um sinergismo entre as substâncias ${ }^{47,66,68}$. Pesquisas também têm revelado ação anticariogênica $24,70,71$ e antiplaca 47,49,74 no emprego dessa combinação.

O esteviosídeo é outra substância que também tem sido estudada com finalidade anticariogênica ${ }^{22,55,79}$ e antiplaca ${ }^{11,17,84,96,109}$. Essa substância é um glicosídeo cristalino, 300 vezes mais doce que a sacarose, sendo um componente natural, extraído das folhas da Stévia rebaudiana Bertoni, nativa das regiões limítrofes de Brasil e Paraguai,

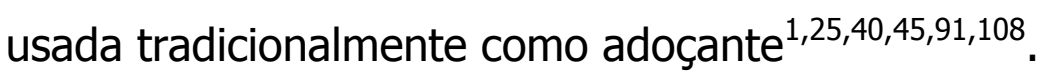

O primeiro estudo referente ao esteviosídeo, em relação à Odontologia, foi o de YABU et al. ${ }^{107}$, em 1977, que observaram uma limitação no crescimento de microrganismos e influência nas atividades da glicosiltransferase quando, ao meio, adicionava-se a glicose. Pelos trabalhos de BERRY; HENRY ${ }^{9}$ e YABU et al. ${ }^{107}$ demonstrou-se a não metabolização do esteviosídeo pelos microrganismos bucais, especificamente o S. mutans até ácidos, que desmineralizariam 0 esmalte.

O esteviosídeo possui o tanino em sua composição, o qual altera qualitativamente a produção de polissacarídeos extracelulares, agindo na aderência das bactérias à superfície dentária ${ }^{51,82}$ e inibe a síntese de polissacarídeos pelos S. mutans e S. sanguis ${ }^{83}$ e dessa forma poderia ser responsável pelo seu efeito antiplaca.

A associação com o fluoreto de sódio em pH acidulado é interessante, a fim de verificar se existe uma somatória de ação dessas substâncias, visto que trabalhos têm demonstrado que o fluoreto de sódio em pH ácido, apresenta eficiência em inibir tanto o metabolismo ${ }^{10,104}$ quanto o acúmulo de placa dentária ${ }^{109}$. Também o 
estudo de KLEBER ${ }^{55}$, realizado em animais de laboratório, revelou um efeito anticariogênico no emprego de uma solução contendo esteviosídeo $0,5 \%$ associado ao fluoreto de sódio $0,02 \%$ e, o de BIJELLA et al. ${ }^{11}$, desenvolvido em crianças, verificou diminuição do acúmulo de placa dentária, com uma solução de esteviosídeo 0,5\% associado ao fluoreto de sódio $0,05 \% \mathrm{pH}$ acidulado.

O esteviosídeo apresenta interesse premente por ser um adoçante natural, não possuindo efeitos tóxicos, mesmo se a criança ingeri-lo e não existindo registros de efeitos colaterais pelo seu uso contínuo ${ }^{1,136}$.

Considerando-se o valor da prevenção da cárie dentária para a Odontopediatria e sabendo-se da importante relação da placa dentária e dos estreptococos mutans sobre a mesma, torna-se válida toda pesquisa clínica de substâncias que apresentem ação antiplaca e antimicrobiana, procurando-se adequá-las às características das crianças. E, assim, possibilitar sua aplicação como auxiliares dos métodos convencionais exercidos na rotina diária das mesmas. 
2 - REVISÃO DE LITERATURA 


\section{2 - REVISÃO DE LITERATURA}

Esta revisão foi dividida em 3 partes, no intuito de individualizar o estudo da clorexidina associada ou não ao fluoreto de sódio e do esteviosídio.

\section{1 - Clorexidina}

A maioria dos trabalhos encontrados na literatura refere-se à aplicação da clorexidina em adultos, utilizando-se diferentes métodos, volumes, concentrações e freqüências. Existem estudos que avaliaram a clorexidina em solução para bochechos, nas concentrações $0,1 \%{ }^{36,101} \mathrm{e}$ $0,12 \%^{2,26,39,80,81,85,86,27}$, os quais demonstraram ação sobre a placa dentária. Essas pesquisas encontraram reduções no índice de placa que variaram de $49 \%$ a $88 \%$, revelando ser a clorexidina, nessas concentrações, uma eficiente substância antiplaca.

Desse modo, procurou-se selecionar alguns trabalhos, para posteriormente poder correlacioná-los na discussão.

LÖE; SCHIÖTT ${ }^{63}$ (1970), realizaram uma pesquisa envolvendo 24 estudantes de odontologia entre 20 e 25 anos de idade, para averiguar os efeitos de bochechos com gluconato de clorexidina 0,2\% e aplicação tópica dessa solução a 2,0\%, sobre o desenvolvimento da placa dentária e gengivite. Previamente ao período experimental, os participantes receberam profilaxia profissional, foram instruídos a 
praticarem uma higiene bucal meticulosa e examinados periodicamente até que o índice de placa ficasse próximo de zero. Depois disso, os procedimentos de higiene bucal foram suspensos e os participantes divididos em 4 grupos $(A, B, C, D)$, sendo que 2 deles bochecharam com 10 $\mathrm{ml}$ da solução por 1 minuto, da seguinte forma: o grupo $A$ utilizou a solução 2 vezes ao dia, por 22 dias e, após esse período cessou a higiene bucal habitual, bem como os bochechos com o agente antimicrobiano por 11 dias e o grupo B realizou bochechos 1 vez ao dia, por 40 dias sem higiene bucal. $\mathrm{O}$ grupo $\mathrm{C}$ (controle) não executou os bochechos nem a higiene bucal durante 22 dias. 0 grupo $D$, recebeu uma aplicação tópica diária da solução a $2 \%$ por 1 minuto, durante 15 dias e após 4 semanas dessa fase, uma segunda etapa foi executada aplicando-se diariamente uma solução placebo de cloreto de quinino $0,1 \%$, por 15 dias. 0 índice de placa foi determinado por um único examinador, utilizando-se os critérios de SILNESS; LÖE. O índice de placa do grupo A foi de 0,05, após 22 dias de experimento, mostrando a prevenção da formação de placa em praticamente todas as superfícies dentárias e, após os 11 dias, sem os bochechos e a higiene bucal, foi similar aos valores do grupo controle. No grupo B, o índice de placa foi 0,22 , com a maior variação entre os participantes enquanto no grupo $D$, os escores variaram de 0 a 0,04 . 0 trabalho demonstrou que bochechos com gluconato de clorexidina $0,2 \%$, duas vezes ao dia, preveniram efetivamente a formação de placa. Manchas marrons foram observadas a partir do $5^{\circ}$ dia no dorso da língua e, no $10^{\circ}$ dia, na língua e dentes nos grupos $A$ e $B$, demorando mais a aparecer no grupo $B$. No grupo $D$, as manchas foram observadas nos dentes de todos participantes e com variação considerável no grau de 
pigmentação. Segundo os autores esta investigação mostra que a aplicação diária de clorexidina pode efetuar a completa inibição de placa e gengivite.

LÖE; VON DER FEHR; SCHIÖTT ${ }^{64}$ (1972) estudaram o efeito de bochechos regulares com gluconato de clorexidina $0,2 \%$ sobre a inibição de formação de placa estimulada ou não pela sacarose. Num período inicial, os 24 participantes receberam profilaxia profissional e instrução de higiene bucal durante um período de 3 a 4 semanas e foram examinados até que 0 índice de placa se aproximasse de zero. Posteriormente, foram divididos em 3 grupos que seguiram regimes diferentes. $O$ grupo 1 cessou toda atividade de higiene bucal e realizou 9 bochechos diários com $10 \mathrm{ml}$ de uma solução de sacarose a $50 \%$, por 2 minutos; o grupo 2 realizou os mesmos bochechos do grupo 1 , além de bochechos com $10 \mathrm{ml}$ de gluconato de clorexidina 0,2\% por 1 minuto, 2 vezes ao dia. O grupo 3 foi subdividido em 2, sendo que um dos subgrupos interrompeu a higiene bucal e bochechou 2 vezes ao dia por 1 minuto com $10 \mathrm{ml}$ de solução de gluconato de clorexidina $0,2 \%$ e o outro foi instruído apenas a praticar meticulosamente a higiene bucal. 0 período experimental durou 22 dias, sendo o índice de placa de SILNESS; LÖE registrado nos dias 1, 3, 5, 10, 15 e 22 e, o índice gengival de LÖE; SILNESS, nos dias 10, 15 e 22. O exame final de todos os grupos demonstrou que a formação de placa foi bem menor no grupo 2, com escore médio no último dia de 0,43. No grupo 3, o subgrupo que utilizou clorexidina sem o subgrupo que efetuou apenas a higiene bucal e o que utilizou clorexidina sem higiene bucal e o que efetuou apenas a mesma, não acumularam placa, apresentando um escore médio no último dia de 
0,05 e 0,08, respectivamente. Não houve mudanças significantes nos grupos que utilizaram sacarose e clorexidina, só a clorexidina ou que realizou boa higiene bucal. Os autores concluíram que a formação da placa dentária é prevenida pela administração diária de gluconato de clorexidina, sendo mais efetiva para a placa não estimulada, e que a higiene bucal adequadamente realizada tem sua importância.

Com a finalidade de se avaliar a relação volume/concentração e método de aplicação de solução de clorexidina, efetiva no controle da formação de placa, CUMMING; LÖE ${ }^{21}$ (1973) realizaram uma pesquisa com 44 estudantes, num modelo duplo-cego. Os métodos utilizados foram de irrigação e de bochechos, em que o tempo variava de acordo com o volume da solução. A irrigação foi realizada como se segue: $700 \mathrm{ml}$ por 90 segundos, $400 \mathrm{ml}$ por 60 segundos e 200 $\mathrm{ml}$ por 30 segundos. Para os procedimentos de bochecho foram empregados: 100 segundos para $200 \mathrm{ml} ; 70$ segundos para $100 \mathrm{ml} ; 45$ segundos para $50 \mathrm{ml}$ e 30 segundos para $20 \mathrm{ml}$. Durante os períodostestes que duravam 9 dias, a higiene bucal foi suspensa e um período de 5 dias foi dado entre cada fase. As concentrações de clorexidina utilizadas foram: $0,01 \% ; 0,05 \% ; 0,075 \% ; 0,1 \% ; 0,15 \%$ e $0,2 \%$, sendo que os estudantes utilizaram a solução placebo e todas as concentrações de clorexidina no volume específico de seu grupo. Os escores do índice de placa de SILNESS; LÖE foram menores quanto maior a concentração de clorexidina até se alcançar um nível, onde o aumento não interferiu nos mesmos. Em relação à irrigação, as concentrações $0,05 \%$ e $0,1 \%$, nos diferentes volumes, determinaram escores de placa que variaram de 0,2 a 0,3 . Nos bochechos a concentração $0,1 \%$ e a $0,2 \%$, com volumes de 
$50 \mathrm{ml}$ e $20 \mathrm{ml}$, o índice de placa final foi de 0,35 e 0,40, respectivamente. A superfície lingual foi a área de menor índice de placa, com exceção dos molares inferiores no grupo dos bochechos. A seguir, foi a superfície vestibular, em especial nos dentes anteriores. As superfícies interproximais foram as que apresentaram maior índice de placa. Os autores destacaram que as manchas tendem a aumentar, conforme se eleva a concentração de clorexidina e o volume da solução. Essa pigmentação foi o único efeito colateral observado durante os 3 meses de trabalho.

GJERMO et al. ${ }^{37}$ (1975) pesquisaram a retenção de uma solução de clorexidina $0,2 \%$ com diferentes pHs $(1,5,3,0,6,4$ e 9,0) ministrada em bochechos, e a sua ação antiplaca. Como controles, foram utilizadas uma solução de água destilada e uma solução aquosa de ácido acético pH 3,0. Os 14 participantes, estudantes de odontologia, receberam profilaxia profissional e a seguir utilizaram $10 \mathrm{ml}$ de solução por 1 minuto, 2 vezes ao dia, durante 3 dias. Um intervalo de 4 dias, para voltar à rotina de higiene bucal, foi dado entre os períodos experimentais. Não se permitiu a higiene bucal durante o experimento e a placa foi avaliada através do índice de LÖE. A placa foi estimulada através de 8 bochechos com $10 \mathrm{ml}$ de uma solução de sacarose a $15 \%$ por 1 minuto, 1 vez ao dia. Um teste bacteriológico "in vitro" também foi desenvolvido para verificar a atividade antimicrobiana do digluconato de clorexidina, em diluição seriada, nos pHs 2,0 e 6,2 contra estreptococos mutans. Os autores relataram índice de placa 0,22, com redução percentual de $76 \%$, quando da utilização do $\mathrm{pH}$ 6,4 e resultado semelhante para o $\mathrm{pH}$ 9,0 (índice de placa 0,27 e redução percentual 71\%). Para as demais 
soluções existiu uma redução do efeito inibidor de placa. A curva de pH obtida para retenção bucal e a curva da efetividade clínica foram semelhantes em todas as soluções com diferentes $\mathrm{pH}$, propondo que $\mathrm{o}$ efeito clínico possa ser baseado na ligação da clorexidina às proteínas da boca. Nenhuma diferença na atividade antibacteriana contra os estreptococos mutans foi encontrada com a utilização da clorexidina em água deionizada ( $\mathrm{pH} \mathrm{6,2)} \mathrm{e} \mathrm{em} \mathrm{ácido} \mathrm{clorídrico} \mathrm{0,2 \%} \mathrm{(pH} \mathrm{2,0).} \mathrm{A} \mathrm{inibição,}$ de placa para ambas, nos níveis dessa bactéria após 2 minutos de exposição foi obtida em aproximadamente $150 \mu \mathrm{g}$ de clorexidina/ml.

LÖE et al. ${ }^{65}$ (1976) procuraram examinar, a longo prazo (2 anos), os efeitos da aplicação diária de clorexidina sobre o desenvolvimento da placa dentária, cálculo e patologia periodontal, bem como monitorar mudanças na microbiologia bucal e qualquer efeito sistêmico ou local. Após um exame inicial, 120 estudantes (entre 20 e 26 anos de idade), foram selecionados e separados em 2 grupos. 0 grupo experimental utilizou gluconato de clorexidina $0,2 \%$ e o controle, uma solução similar, sem a substância ativa. Um período pré-experimental de 3 meses foi conduzido para averiguar quais os níveis de placa e gengivite presentes, antes da introdução do gluconato de clorexidina, no regime de higiene bucal habitual. Nessa fase, os participantes, após terem se submetido à profilaxia profissional, escovaram os dentes no método circular, uma vez ao dia, com dentifrício sem substância ativa e realizaram bochechos com $10 \mathrm{ml}$ de solução não terapêutica, uma vez ao dia, por 60 segundos. As informações foram coletadas através dos índices de placa de SILNESS; LÖE, gengival de LÖE; SILNESS e o de cálculo de VOLPE, MANHOLD; HAZEN. Ao final desse período, também foram 
coletadas amostras de saliva e informações relacionadas ao estado de saúde dos pacientes. Terminada a fase pré-experimental, os estudantes receberam nova profilaxia profissional, exame do índice de placa e foram realizadas fotografias coloridas da face vestibular dos dentes, coleta de amostras de placa e saliva; exames clínicos e radiográficos também foram realizados para identificar a presença de cárie. Após as avaliações iniciais, os grupos foram orientados a escovarem os dentes com dentifrício não terapêutico por 30 segundos, pela manhã, utilizando o método circular e, à noite por 60 segundos, com $10 \mathrm{ml}$ de uma das soluções. Nessa fase, as avaliações dos índices de placa, gengival e de cálculo foram feitas após o primeiro, segundo, terceiro, sexto e nono meses. Iniciou-se então, um terceiro período, no qual foi executada nova profilaxia profissional sendo o grupo experimental instruído a bochechar, por 1 minuto, $10 \mathrm{ml}$ da solução de gluconato de clorexidina 0,2\% e o controle, uma solução placebo. Permitiu-se a escovação habitual e após 3 meses, dentro dessa rotina, nova bateria de exames foi conduzida; posteriormente, todos se submeteram à profilaxia profissional. Em seguida, o esquema de bochechos com a clorexidina foi empregado por mais 1 ano e depois desse tempo, determinou-se a história médica dos pacientes através de novo questionário.

Em 8 meses houve redução do índice de placa de 38\% e $53 \%$ para o grupo controle e experimental, respectivamente, havendo diferença estatisticamente significante entre eles. Com a adoção dos bochechos com a solução de gluconato de clorexidina 0,2\%, o índice de placa continuou a diminuir, principalmente nas faces proximais, ficando próximo a 0,5. A aplicação em forma de bochechos foi superior à de 
escovação e o efeito máximo dessa concentração foi observado no $1^{0}$ mês de uso, mantendo-se até o final (índice de placa próximo a 0,3). A clorexidina utilizada na escovação promoveu maior pigmentação do que quando empregada na forma de bochechos e foi estatisticamente significante em relação ao controle. O grupo da clorexidina demonstrou maior índice de cálculo que o controle, porém não estatisticamente significante. Não foram observados efeitos adversos aparentes na estrutura e função dos tecidos bucais, nem prejuízo no paladar, nem sinais clínicos refletindo mudanças maiores na ecologia bucal, nem pigmentação na língua. Quando se suspendeu o uso dessa substância, evidenciou-se diminuição no grau de pigmentação em 4 meses, ficando semelhante ao controle, entretanto, $50 \%$ do grupo do gluconato de clorexidina não mostrou esse efeito colateral. Os autores concluíram que o tratamento com clorexidina reduziu o acúmulo de placa e gengivite e não observaram o desenvolvimento de problemas sistêmicos.

No estudo desenvolvido por SCHIÖTT; BRINER; LÖE ${ }^{93}$ (1976), que utilizaram os mesmos pacientes que participaram da pesquisa de LÖE et al., foi avaliado o número de bactérias anaeróbias, aeróbias e estreptococos mutans na saliva, antes, durante e após o tratamento com gluconato de clorexidina $0,2 \%$. Amostras de saliva estimulada foram coletadas após os 3 meses do período inicial e todo mês, quando do príncipio do período experimental até completar 6 meses de estudo. Posteriormente a coleta foi executada no $9^{\circ}{ }_{4} 10^{\circ}, 13^{\circ}, 15^{\circ}, 17^{\circ}$, $23^{\circ}$ e $24^{\circ}$ meses dessa fase experimental e no $2^{\circ}$ e $5^{\circ}$ meses da etapa pós-experimental, quando os indivíduos apenas executavam sua higiene bucal habitual. $O$ tratamento com clorexidina resultou numa redução de 
$20 \%$ a $50 \%$ no número de bactérias salivares e o número de estudantes, nos quais os estreptococos mutans puderam ser isolados da saliva, decresceu durante o tratamento. As contagens totais mostraram maior redução no $1^{0}$ mês (de $179 \times 10^{6}$ para $89 \times 10^{6} \mathrm{UFC} / \mathrm{ml}$ ), permanecendo semelhantes até $015^{\circ}$ mês com tendência aos valores iniciais, quando 0 regime foi cessado. Essa redução no número de bactérias, na saliva, não produziu mudanças indesejáveis na ecologia bucal parecendo compatível com a fisiologia bucal.

BONESVOLL $^{13}$ (1978) estudou a relação entre concentração e freqüência de uma solução contendo clorexidina, com a retenção e inibição do acúmulo de placa. Na avaliação da retenção, 4 experimentos foram realizados, dando-se um intervalo mínimo de uma semana, num grupo de 35 indivíduos entre 31 e 42 anos. Em 3 experimentos, os bochechos consistiram de $10 \mathrm{ml}$ de solução contendo digluconato de clorexidina $0,05 \% ; 0,1 \%$ ou $0,2 \%$. No quarto experimento, a quantidade foi aumentada para $20 \mathrm{ml}$ na concentração 0,05\%. A retenção foi medida durante 10 bochechos consecutivos de 15 segundos, feitos com intervalos de 10 segundos. Após o último bochecho com a solução experimental, foram executados 3 bochechos com água deionizada, por 1 minuto. $O$ estudo de inibição do acúmulo de placa foi feito em 5 experimentos duplo-cego, onde 10 participantes, com idades entre 19 e 22 anos, receberam no início profilaxia profissional. A solução de digluconato de clorexidina foi utilizada nas concentrações 0,05\% e $0,1 \%$. O tempo de bochecho para a concentração $0,05 \%$ foi de 15 segundos com freqüência de 4 vezes ao dia quando utilizada no volume de $10 \mathrm{ml}$, e de 2 ou 3 vezes ao dia, no volume de $15 \mathrm{ml}$. Na concentração 
0,1\%, foi empregado um volume de $10 \mathrm{ml}$ por 60 segundos, uma vez ao dia. A solução controle não continha a substância ativa. Os bochechos foram realizados por 3 dias, dando-se intervalo de 7 dias entre eles. Os participantes tiveram a fermentação de placa estimulada, utilizando 7 bochechos com $10 \mathrm{ml}$ de solução contendo sacarose $15 \%$, por 1 minuto, feitos das $8 \mathrm{~h}$ às $22 \mathrm{~h}$. A média de retenção total do bochecho com clorexidina $0,2 \%$ foi $11,6 \mathrm{mg}$ e na concentração $0,1 \%$, bochechada por 1 minuto, o valor foi de $10 \mathrm{mg}$. Os autores concluíram que para atingir igual nível de retenção oferecido por $10 \mathrm{ml}$ de solução na concentração de $0,1 \%$, bochechada por 1 minuto, diariamente, seria necessário o mesmo volume da solução a 0,05\% utilizados por 15 segundos, 4 vezes ao dia ou $20 \mathrm{ml}, 3$ vezes ao dia. A redução de placa nesses casos foi de $81 \%, 85 \%$ e $80 \%$, respectivamente.

BELLINI et al. ${ }^{8}$ (1980) avaliaram a capacidade de inibição de placa do gluconato de clorexidina na forma de aplicação tópica e bochechos, considerando as vantagens e desvantagens desses métodos de aplicação. Estudantes de Odontologia, entre 21 e 26 anos de idade, participaram de 2 esquemas de utilização, sendo que um realizava bochechos com $20 \mathrm{ml}$ de gluconato de clorexidina 0,2\%, divididos em 2 etapas de $10 \mathrm{ml}$ por 30 segundos, por 2 semanas e, o outro, utilizava a mesma substância a 2,0\%, auto-aplicada com cotonetes, pelo mesmo período que a etapa anterior. Houve um intervalo de 12 dias entre os esquemas, no qual os participantes foram mantidos sob controle, com instrução de higiene bucal utilizando escova, fio dental e dentifrício padronizados. A formação de placa foi avaliada pelo índice de SILNESS; LÖE ao início e ao término de cada etapa, por um único examinador e um 
questionário foi respondido ao final da pesquisa pelos participantes. 0 índice de placa manteve-se próximo de zero nas etapas de controle químico e mecânico, sendo de 0,20 para a aplicação tópica, 0,23 para o bochecho e 0,25 para o controle mecânico. A pigmentação dentária foi observada nos dois métodos de aplicação do gluconato de clorexidina e mais intensa nos dentes e língua com os bochechos (35\%). A resposta ao questionário indicou que o sabor amargo também foi mais acentuado com a utilização do bochecho, do mesmo modo que a alteração no sabor dos alimentos, porém esse método foi considerado de uso mais fácil.

Para estudar o efeito na inibição do acúmulo de placa, de bochechos com digluconato de clorexidina 0,2\%, ASIKAINEN et al. ${ }^{6}$ (1981) testaram duas soluções comerciais (Plak-Out-solução concentrada de digluconato de clorexidina e Hibitante Dental) e uma preparada em laboratório. Os bochechos foram realizados com $10 \mathrm{ml}$ de solução por 1 minuto, duas vezes ao dia, durante 3 períodos testes, de uma semana cada. Estudantes de Odontologia, num total de 30, participaram de todos os períodos, quando nenhum recurso de higiene bucal foi permitido. Entre os testes houve um intervalo de uma semana, considerado controle, no qual foi permitida a higiene bucal. Ao término de cada período, teste e controle, um único examinador executou o índice de placa de SILNESS; LÖE. Os autores verificaram uma diferença estatisticamente significante em favor da limpeza química comparada à limpeza mecânica dos dentes. Entre os 3 períodos de testes com bochechos de clorexidina não existiu diferenças estatisticamente significantes no índice de placa, ficando o mesmo em torno de 0,1, com redução percentual próximo de $75 \%$. Houve maior formação de placa na 
mesial e lingual após a higiene bucal do que com os bochechos de digluconato de clorexidina; já na face vestibular, não houve diferença. As opiniões dos participantes foram analisadas após cada semana de bochecho. Houve queixa de perda da sensação do paladar, dor, irritação e secura da mucosa bucal, sendo a perda de sensação do paladar mais freqüente com o Plak-Out. As pigmentações dentárias, avaliadas por fotografias coloridas, tiveram uma leve tendência a serem mais intensas após o uso do Plak-Out. Com relação ao efeito antiplaca, os autores concluíram que não houve diferença entre as soluções de digluconato de clorexidina 0,2\%. A adição de substâncias para dar sabor às soluções de clorexidina testadas foram favoráveis, pois não interferiram na eficiência da substância.

ROBERT; ADDY $^{87}$ (1981) tiveram como metas comparar a propriedade bactericida de 4 soluções anti-sépticas e determinar a duração do efeito sobre a microbiota salivar, "in vivo". Para o estudo da contagem bacteriana salivar, um grupo de 10 voluntários realizou um único bochecho por 1 minuto, com $10 \mathrm{ml}$ de solução de uma das soluções que se segue: gluconato de clorexidina $0,2 \%$, alexidina $0,035 \%$, hexidina 0,1\%, cloreto de cetilpiridíneo 0,05\% e água esterilizada, com coleta de amostras de saliva após de 2, 30, 90 minutos e 3, 5, 7 e 24 horas. Todos os participantes utilizaram todas as substâncias com intervalo de 7 dias entre os bochechos. Após os bochechos com os 4 anti-sépticos catiônicos, houve uma queda nas contagens bacterianas salivares, em aero e anaerobiose, sendo mais marcante para o gluconato de clorexidina. No caso da água, as contagens não diferiram significantemente dos níveis pré-bochecho e para os 4 anti-sépticos 
permaneceram menores até 90 minutos. Posteriormente a esse tempo, as contagens para a hexidine voltaram a níveis que não diferiram significantemente do início. Para as demais, a diferença permaneceu significante até 3 horas para o cloreto de cetilpiridíneo, até 5 horas para alexidine e até 7 horas para a clorexidina. Em termos de percentagem, a queda média imediata nas contagens salivares foi similar para a alexidine, gluconato de clorexidina e cloreto de cetilpiridíneo, variando de $91 \%$ a $95 \%$ de redução. Todos os anti-sépticos foram efetivos em diminuir a concentração dos microrganismos testados (S. mutans, S. sanguis, E. coli, estafilococos Oxford e C. albicans). Os autores concluíram que a mensuração da propriedade antibacteriana, em particular, a duração do efeito " in vivo ", pode ser relevante para a atividade antiplaca dos antisépticos catiônicos.

ZICKERT; EMILSON; KRASSE ${ }^{110}$ (1982) desenvolveram um estudo longitudinal de 3 anos, com 101 crianças de 13 a 14 anos de idade. As crianças foram divididas em 2 grupos de estudo (controle e teste), que posteriormente foram subdivididas em subgrupos de acordo com o nível de estreptococos mutans na saliva: $<2,5 \times 10^{5}, \geq 2,5 \times 10^{5}$ e $<10^{6}$ e $>10^{6} / \mathrm{ml}$. No grupo teste, as crianças com média maior que $2,5 \times 10^{5}$ estreptococos mutans por $\mathrm{ml}$ de saliva foram selecionadas para tratamento, com a finalidade de reduzir a população microbiana. Após cuidadosa profilaxia profissional, um gel $(\mathrm{pH} \mathrm{7,2)} \mathrm{contendo} \mathrm{digluconato}$ de clorexidina a $1 \%$ foi aplicado nos dentes por 5 minutos, uma vez ao dia, durante 14 dias e, posteriormente nova contagem do microrganismo foi realizada para determinar se havia ocorrido uma queda satisfatória. Outras coletas de amostra de saliva foram feitas a cada 4 meses, durante 
3 anos. Quando o número de estreptococos mutans era reduzido abaixo de $2,5 \times 10^{5}$ por $\mathrm{ml}$ de saliva nas crianças do grupo teste, era realizado o selamento dos pré-molares e molares. Sempre que as crianças exibiam mais de $2,5 \times 10^{5}$ estreptococos mutans por $\mathrm{ml}$ na saliva numa amostragem, eram tratadas com o gel de digluconato de clorexidina a $1 \%$, em casa, por 14 dias e o efeito desse re-tratamento verificado em nova amostra de saliva. $\mathrm{O}$ nível de estreptococos mutans, nas crianças do grupo controle, foi determinado a cada 6 meses e orientavam-se as mesmas, sobre a importância da dieta e bons hábitos de higiene bucal.

Durante essa pesquisa, 9 crianças não foram tratadas, 6 crianças o foram só uma vez, 9 crianças 2 a 3 vezes e 20 crianças, 4 a 9 vezes. Um total de 162 tratamentos, com o gel de digluconato de clorexidina a $1 \%$, foi executado durante os 3 anos de período experimental no grupo teste e a média de estreptococos mutans decresceu de $7,5 \times 10^{5}$ para $0,2 \times 10^{5}$. As crianças mais infectadas (mais de $10^{6}$ ), foram as mais tratadas (6 a 9 vezes) e as menos infectadas, em média 1,5 vez. Existiu diferença estatisticamente significante, entre os grupos controle e teste, no número total de novas lesões de cárie; e essa diferença foi mais evidente no grupo que apresentava mais de $10^{6}$ estreptococos mutans, por $\mathrm{ml}$ de saliva. O melhor efeito do tratamento foi visto nas superfícies vestibular e lingual. A redução por um período de 3 a 4 meses, no nível de estreptococos mutans, dada pelo digluconato de clorexidina pode ter favorecido a remineralização de lesões iniciais de esmalte e ter retardado o desenvolvimento de novas lesões. Os resultados, segundo os autores, mostram que a atividade de cárie pode ser controlada em crianças com altas contagens de estreptococos 
mutans, pelo uso da clorexidina. O efeito foi especialmente pronunciado naquelas crianças que inicialmente tinham alto número de estreptococos mutans, com redução de cárie de cerca de $80 \%$, comparadas com as do grupo controle.

LANG et al. ${ }^{61}$ (1982) pesquisaram em crianças, os efeitos de bochechos supervisionados com digluconato de clorexidina sobre a placa dentária e a gengivite, a aceitação da solução pelas crianças e a ocorrência e severidade de efeitos colaterais. A solução foi utilizada durante 6 meses, em 158 crianças com idades entre 10 e 12 anos e os bochechos supervisionados por uma Técnica em Higiene Dental durante 0 período escolar. As crianças receberam profilaxia profissional no início e no final do experimento. Os bochechos eram realizados utilizando-se 15 $\mathrm{ml}$ de solução por 30 segundos, sendo os hábitos de higiene bucal preservados. Antes da profilaxia inicial e após 6 meses de experimento avaliou-se o efeito da clorexidina, utilizando-se o índice de placa de LÖE. A amostra foi dividida em 4 grupos: grupo $A$, bochechos com digluconato de clorexidina 0,2\%, uma vez ao dia, 6 vezes por semana; grupo B, bochechos com a mesma solução $(0,2 \%), 1$ vez ao dia, 2 vezes por semana; grupo $C$, bochechos com clorexidina 0,1\%, 1 vez ao dia, 6 vezes por semana; grupo $D$, bochechos com solução placebo, 1 vez ao dia, 6 vezes por semana. Após os 6 meses de experimento, a redução de placa foi estatisticamente significante $(p<0,05)$ em todos os grupos que trataram com digluconato de clorexidina, quando comparados com 0 grupo controle. Entretanto, isso não foi observado entre os grupos experimentais. Os escores médios dos grupos após 6 meses foram de 1,24 (A), 1,34 (B), 1,29 (C) e 1,53 (D). Segundo os autores, houve 
melhor redução do escore médio de placa apenas nos grupos que bochecharam 6 vezes por semana, usando o digluconato de clorexidina 0,2\% (Grupo A - 19,4\%) ou 0,1\% (Grupo C - 16,2\%). Os efeitos colaterais foram secundários. Houve pigmentação marrom, de forma suave, nos dentes das crianças que bochecharam com digluconato de clorexidina com diferença estatisticamente significante em relação ao grupo controle. Houve maior pigmentação no grupo que usou digluconato de clorexidina $0,2 \%$ regularmente em relação a solução 0,1\%, sugerindo relação da concentração e dose no desenvolvimento da mesma. As manchas e os bochechos foram considerados aceitáveis pelas crianças, não se observando nenhuma lesão bucal; todos os grupos que bochecharam com digluconato de clorexidina apresentaram uma fina camada de cálculo supragengival, sendo praticamente ausentes os depósitos subgengivais. Segundo os autores, apesar das soluções de digluconato de clorexidina $0,2 \%$ e 0,1\% serem aceitáveis, como a última apresenta menor manchamento nos dentes, deveria ser recomendada na utilização por períodos mais longos.

SEGRETO et al. ${ }^{94}$ (1986) compararam o efeito de duas concentrações de clorexidina sobre a gengivite e o acúmulo de placa. 0 estudo clínico foi duplo-cego, com a participação de 597 voluntários adultos, por um período de 3 meses. Após os exames iniciais, os pacientes receberam profilaxia profissional e foram divididos em 3 grupos conforme a idade, sexo e severidade de gengivite: grupo 1, utilizou gluconato de clorexidina $0,12 \%$; grupo 2 , gluconato de clorexidina $0,2 \%$; e grupo 3, solução placebo com idêntica composição das demais soluções, exceto o ingrediente ativo. Foram dadas instruções para que 
realizassem bochechos 2 vezes ao dia, por 30 segundos com $10 \mathrm{ml}$ de solução e mantivessem os hábitos de higiene bucal. A avaliação clínica, para a gengivite, foi feita usando o índice de LÖE e o índice de gengivite marginal papilar e, para o acúmulo de placa, o índice de TURESKY et al. Nos tecidos moles realizou-se um exame tactil-visual, a fim de detectar possíveis efeitos colaterais da clorexidina. A ocorrência de gengivite foi significantemente menor nos 3 meses de estudo para as 2 concentrações de clorexidina, na comparação com o grupo placebo, sendo de $34 \%$, em média, para a de $0,12 \%$ e $28 \%$ para a de $0,2 \%$ sem diferença estatística entre ambas. Sobre a placa dentária, após 3 meses, houve uma redução significante de $36,1 \%$ para o grupo da clorexidina $0,12 \%$ e de $27,8 \%$ para o grupo da $0,2 \%$, quando comparados ao placebo sem diferença estatisticamente significante entre as duas concentrações. Com exceção de alguns comentários subjetivos, não existiu diferença no exame dos tecidos bucais que pudessem indicar efeitos adversos produzidos pela clorexidina. Os autores concluíram que os bochechos com gluconato de clorexidina $0,12 \%$ oferecem os mesmos benefícios clínicos que os de concentração $0,2 \%$.

SCHAEKEN et al. ${ }^{92}$ (1986) estudaram o efeito de um tratamento antimicrobiano intensivo sobre o número de S. mutans, S.sanguis, Actinomyces viscosus e Actinomyces naeslundii na placa e na saliva. Participaram 38 estudantes com idades entre 20 e 33 anos que não apresentavam lesões de cárie detectáveis e que foram distribuídos em 7 grupos com os seguintes tratamentos: grupo I, gel placebo, grupo II, gel de digluconato de clorexidina 5\%; grupo III, solução de fluoreto estanoso 8\%; grupo IV, gel de digluconato de clorexidina $5 \%$ e 
bochechos por 49 dias com clorexidina 0,2\%; grupo V, gel de digluconato de clorexidina $5 \%$ e bochechos por 7 dias com clorexidina 0,2\%; grupo VI, gel de digluconato de clorexidina 5\% e escovação por 7 dias com uma pasta contendo clorexidina; e grupo VII, escovação em casa por 7 dias com gel de digluconato de clorexidina $1 \%$. Antes do tratamento, os estudantes receberam profilaxia profissional e a aplicação do gel contendo clorexidina ou da solução de fluoreto estanoso foi realizada 3 vezes em todas superfícies dentárias, por 3 minutos, com intervalos de 5 minutos entre cada uma. Saliva estimulada foi colhida antes das amostras de placa que foram coletadas de 3 superfícies lisas, 3 de fissuras e 3 de áreas proximais, previamente à profilaxia e dos tratamentos com o gel e o fluoreto estanoso e após 1, 7 e 21 dias dos mesmos. No grupo VI, as amostras foram obtidas 7, 14 e 28 dias após o tratamento com o gel. No grupo controle e no IV, amostras adicionais foram coletadas 35 e 49 dias após o tratamento com o gel. O número de UFC (Unidades Formadoras de Colônias) foi reduzido significantemente 1 dia após o tratamento com o gel de clorexidina e solução de fluoreto estanoso nas amostras de placa obtidas das fissuras e superfícies lisas, mas não nas das regiões interproximais ou nas de saliva. Nos grupos II e III, os estreptococos mutans foram suprimidos após 1 dia em todas as áreas e após 7 dias não houve redução estatisiticamente significante.O grupo IV suprimiu significantemente esses microrganismos em todo período experimental nas fissuras e superfícies lisas e por 35 dias nas superfícies interproximais. Quando a aplicação do gel de clorexidina no consultório foi seguida pelos bochechos com clorexidina $0,2 \%$ ou pela impregnação dessa substância na pasta, os estreptococos mutans permaneceram 
suprimidos por todo tempo em que esses suplementos foram utilizados, tanto na placa como na saliva. Actinomyces viscosus e Actinomyces naeslundii foram suprimidos por 7 dias após aplicação do gel contendo clorexidina, mas não de forma estatisticamente significante depois da aplicação da solução de fluoreto estanoso. Os S. sanguis foram suprimidos na placa das superfícies lisas e na de fissuras após 1 dia da aplicação do gel contendo clorexidina, retornando ao nível inicial 1 semana após a mesma. Os autores relataram que o gel de clorexidina e o fluoreto estanoso suprimiram S. mutans e Actinomyces na placa e saliva e que os bochechos com a clorexidina $0,2 \%$ reduziram $S$. mutans durante o período de tempo que foram utilizados como suplementos.

LACAZ NETTO et al. ${ }^{59}$ (1987) propuseram-se a verificar os efeitos da escovação orientada dos bochechos com digluconato de clorexidina $0,2 \%$ (diluída da solução comercial Plak-Out) e do fluoreto estanoso $0,4 \%$ sobre a formação da placa bacteriana e possíveis efeitos colaterais. $O$ índice de placa utilizado foi o de PODSHADLEY; HALEY, determinado por um único examinador no início e no final de 4 fases da pesquisa, cada uma com 4 dias de duração e intervalo de 3 dias entre elas. Fizeram parte do estudo, 6 estudantes de odontologia, com idade média de 20 anos, os quais receberam profilaxia profissional inicial. $\mathrm{Na}$ fase I, deixou-se acumular placa dentária e os pacientes não executaram a higiene bucal habitual. Nas fase II, III e IV, os regimes foram, respectivamente, escovação orientada, bochecho com fluoreto estanoso $0,4 \%$ e bochecho com digluconato de clorexidina $0,2 \%$, duas vezes ao dia, como únicos meios de higienização. Houve uma redução média de $41 \%$ no índice de placa no uso de bochechos com digluconato de 
clorexidina $0,2 \%$ (fase IV) e de $49 \%$ com a escovação orientada (fase II), quando comparados ao controle, sem nenhum tipo de higiene bucal (fase I). Não existiu diferença estatisticamente significante entre os 3 tratamentos das fases II, III e IV. Em relação à aceitação da solução, o digluconato de clorexidina $0,2 \%$ apresentou um sabor amargo mais intenso, maior interferência na sensação gustativa, sendo que a perda de paladar, para esse método, foi de curta duração. Seis pacientes revelaram uma sensação de secura na boca após utilização dos bochechos. Os autores consideraram que o digluconato de clorexidina 0,2\% manchou bem mais os dentes, sendo também mais difícil sua remoção na profilaxia profissional e também houve pigmentação da língua e restaurações.

AXELSSON; LINDHE$^{7}$ (1987) procuraram determinar, através de um estudo duplo-cego, o efeito sobre a placa dentária e gengivite de diferentes preparações usadas por 6 semanas como suplemento das medidas de higiene bucal,. Participaram do estudo 96 voluntários entre 16 e 50 anos que foram divididos nos 4 grupos de estudo. Sendo os grupos da clorexidina $0,2 \%$ ou a $0,1 \%$ bochecharam com $10 \mathrm{ml}$ por 60 segundos, duas vezes ao dia e o grupo controle e o da Listerine utilizaram $20 \mathrm{ml}$ da solução, por 30 segundos, duas vezes ao dia. Houve supervisão diária, exceto nos finais de semana e feriados. Durante o período da pesquisa, os participantes continuaram a exercer seus hábitos de higiene bucal e dietéticos. Escova e dentifrício fluoretado foram padronizados. Um exame clínico dos tecidos moles foi realizado no início, 3 e 6 semanas de teste. Os exames do índice de placa (TURESKEY et al.) e da pigmentação foram realizados no início, terceira semana e ao 
final do experimento. Os grupos que bochecharam com clorexidina $0,2 \%$ e $0,1 \%$ tiveram após 6 semanas, redução no escore médio de placa de $77 \%$ e $54 \%$ respectivamente, com valores do índice iniciais e finais de 1,4 e 0,3 e de 1,2 e 0,5, de acordo com a ordem acima. Houve um aumento de superfícies livres de placa, após 6 semanas, no grupo da clorexidina $0,2 \%$ de $58 \%$ para $93 \%$ e na concentração $0,1 \%$, de $67 \%$ para 87\%. O maior efeito, com respeito à redução dos escores de placa, ocorreu nas primeiras 3 semanas de teste e esse resultado foi mantido ou aumentou suavemente nas 3 semanas seguintes. Os dados percentuais dessa redução, em 3 semanas foram 61\% para a clorexidina 0,2\% e 57\% para a $0,1 \%$. Em relação às faces vestibular e lingual, essas reduções percentuais foram da ordem de $76 \%$ e $77 \%$, respectivamente, para 0 grupo que utilizou a clorexidina $0,2 \%$ e de $61 \%$ e $50 \%$, respectivamente, para o que utilizou clorexidina $0,1 \%$. A pigmentação dentária extrínseca não foi verificada em nenhum grupo de forma marcante durante as 6 semanas de teste, porém houve desenvolvimento de lesões na mucosa bucal (assoalho de boca, gengiva e vestíbulo) que causaram a desistência do estudo de 8 , dos 96 voluntários.

Tendo por objetivo avaliar a eficácia de bochechos e spray com gluconato de clorexidina $0,2 \%$ e de gel a $1 \%$ sobre a placa dentária, sangramento gengival e pigmentação dentária, FRANCIS; HUNTER; ADDY $^{32}$ (1987) desenvolveram uma pesquisa em crianças excepcionais. Foi feito um estudo piloto, para avaliar o método e identificar as dificuldades, o qual demonstrou que os bochechos não poderiam ser retidos na boca de todas as crianças por 1 minuto. A amostra constou de 49 crianças, entre 5 e 17 anos de idade, que foram divididas em 3 
grupos, nos quais substituiu-se a higiene bucal habitual por um dos regimes de utilização do gluconato de clorexidina. A freqüência de utilização foi de duas vezes ao dia durante 4 semanas, com um intervalo de 3 semanas entre os regimes, quando eram retomados os métodos de higiene bucal habituais. Os bochechos foram feitos com $10 \mathrm{ml}$ de solução por 1 minuto, o gel e spray aplicados por 1 minuto, sendo este último inserido em toda superfície gengival. $O$ volume do spray foi $1 / 5$ do utilizado para bochecho. Antes e após cada período teste, fez-se o índice de placa de SILNESS; LÖE. Todos os tratamentos produziram uma queda no escore médio de placa, sendo que a utilização em gel ocasionou a maior redução e entre a aplicação em bochecho e em spray não houve diferença estatisticamente significante $(p<0,05)$. A pigmentação foi observada em todos os métodos, não havendo diferença clínica ou estatística significante. Os autores salientaram que a solução de gluconato de clorexidina pode ser uma auxiliar útil para a manutenção da higiene bucal, neste grupo de crianças.

ETEMADZADEH et al. ${ }^{30}$ (1989) compararam a ação sobre a formação de placa e o crescimento de microrganismos salivares de uma solução composta por amina-fluoretada e fluoreto estanoso $0.025 \%$, com outra de gluconato de clorexidina $0,12 \%$, utilizadas como bochechos. Um total de 16 participantes, com idade média de 27,5 anos, divididos em 2 grupos, colaborou com a pesquisa de modelo duplo-cego. O estudo consistiu de dois períodos clínicos, com duração de uma semana cada, com pausa de uma semana entre eles. Numa avaliação prévia ao período experimental, os estudantes foram submetidos a uma profilaxia profissional e coleta de saliva. Nas duas semanas seguintes, receberam 
instrução para limpeza bucal meticulosa utilizando dentifrício fluoretado. Antes de se iniciar o período experimental, foram determinados o índice de placa de acordo com SILNESS; LÖE e AINAMO; BAY e o índice gengival de AINAMO; BAY, quando procurou-se aproximá-los de zero. Na etapa de teste, suspendeu-se a higiene bucal e orientou-se o regime de bochechos com $10 \mathrm{ml}$ de solução, por 60 segundos, duas vezes ao dia. Ao final da fase pré-experimental e experimental, além dos exames de placa e gengivite, coletaram dados referentes ao peso de placa e nível de estreptococos mutans e lactobacilos, na saliva. No final de cada etapa de teste, os participantes preencheram um questionário com informações sobre o paladar, a pigmentação e o efeito antiplaca das soluções, numa escala de ruim a bom. A solução de gluconato de clorexidina preveniu eficazmente o acúmulo de placa (próximo de zero), o mesmo não ocorrendo com a solução de amina fluoretada com fluoreto estanoso. Os valores de todos os parâmetros foram menores no início do período experimental, quando comparados com o período pré-experimental. Após uma semana de bochechos com clorexidina, sem higiene bucal, todos os índices foram praticamente iguais aos do início do período experimental. A avaliação subjetiva do efeito de limpeza dos bochechos revelou um efeito maior pela clorexidina, quando comparado à solução fluoretada. No paladar das soluções, não se evidenciou diferença, mas os distúrbios causados no mesmo, pelos bochechos, foram mais distintos para o gluconato de clorexidina o mesmo ocorrendo com a pigmentação nos dentes. A clorexidina determinou redução significante de estreptococos mutans salivar o que não foi observado com o bochecho fluoretado. Um aumento suave, porém não significante, foi verificado na contagem de 
lactobacilos com as duas soluções, ao final do período de uma semana de bochecho.

O objetivo da pesquisa de ADDY et al. ${ }^{4}$ (1989) foi comparar as reações antimicrobianas e de pigmentação "in vitro", de duas formulações comerciais contendo clorexidina $0,1 \%$ e $0,2 \%$, em solução para bochechos, bem como de suas diluições $(0,05 \%, 0,03 \%$ e $0,02 \%$ para a primeira e $0,1 \%, 0,05 \%, 0,03 \%$ e $0,02 \%$ para a segunda). No estudo da pigmentação foi utilizado um componente de pigmentação encontrado na solução padrão do chá e dentes recém-extraídos. Duas vezes ao dia e por 5 dias consecutivos, os dentes foram colocados num "pool" de saliva humana por 10 minutos, removidos e lavados em água destilada, antes de serem inseridos na solução teste, por 2 minutos. Após a exposição às respectivas soluções, os espécimes foram retirados, lavados em água destilada e imersos na solução padrão de chá e, posteriormente analisados por critério de pigmentação estabelecido. Os resultados demonstraram que os espécimes expostos às formulações de clorexidina $0,1 \%$ mostraram pigmentação suave, como a dos expostos à solução controle e aqueles que foram imersos na concentração 0,2\%, bem como suas diluições, mostraram progressiva pigmentação em 5 dias, em sua maioria graduada como pigmentação pesada. Na avaliação microbiológica foram utilizados vários microrganismos, entre eles, espécies de estreptococos, utilizando-se o teste de diluição em ágar. Os autores concluíram que o efeito antimicrobiano dos 2 produtos foi similar, mas de uma forma geral, a preparação $0,1 \%$, sugeriu atividade de ingredientes outros que a clorexidina, possivelmente detergentes. 
Visando avaliar a magnitude e duração da ação sobre as contagens bacterianas salivares, de soluções para bochechos contendo clorexidina, ADDY; JENKINS; NEWCOMBE ${ }^{3}$ (1991) desenvolveram uma pesquisa com 10 estudantes de odontologia, com idades entre 20 e 26 anos. A clorexidina $0,2 \%$ foi usada com volume de $10 \mathrm{ml}$ de solução enquanto a clorexidina $0,12 \%$ (solução comercial), a clorexidina $0,1 \%$ (solução não comercial) e a solução salina foram utilizadas com volume de $15 \mathrm{ml}$. O tempo de bochecho foi de 1 minuto para todas as soluções. O estudo foi executado por um único examinador num modelo cego e cruzado. As soluções foram prescritas ao acaso, observando um período de 2 dias e meio entre as etapas. Amostras de saliva foram coletadas no início, 30, 60, 180, 300 e 420 minutos após os bochechos e processadas logo em seguida. No início, não houve diferença significante entre as contagens nos 4 grupos de tratamento. A solução salina não provocou reduções significantes nas contagens e aumento significante foi observado nos tempos de 300 e 420 minutos. As soluções de clorexidina, nas concentrações $0,2 \%, 0,12 \%$ e $0,1 \%$ produziram reduções significantes comparadas com a contagem inicial, em todos períodos do tratamento. Entre as concentrações 0,2\% e 0,12\%, a magnitude dos efeitos foi similar, sendo maior que o efeito obtido com a concentração $0,1 \%$. A clorexidina $0,2 \%$ teve pequeno efeito sobre as contagens bacterianas com redução significante apenas nos 30 minutos. Os resultados das soluções de clorexidina 0,2\% e 0,12\% sobre as contagens salivares foram sempre melhores do que as da solução $0,1 \%$. Os autores concluíram que os resultados obtidos foram consistentes com estudos comparativos de inibição de placa usando essas substâncias, sugerindo 
que o método é simples e rápido para examinar produtos com potencial antiplaca e antibacteriano.

Com a finalidade de obter mais informações sobre as propriedades de inibição de placa do triclosan, sanguinarina, produtos naturais (incluindo eugenol, timol, camomila, mirra e ratani) e clorexidina 0,2\%, comparadas com um controle (solução salina), MORAN; ADDY; ROBERTS $^{76}$ (1992) realizaram uma pesquisa envolvendo 18 voluntários, com idade média de 26 anos e 4 meses, que no princípio de cada etapa receberam profilaxia profissional. A pesquisa se desenvolveu em 9 fases de 4 dias, durante as quais não se efetuou a higiene bucal. Um intervalo de 72 horas foi empregado, entre as etapas, no qual os hábitos de higiene bucal foram permitidos. As soluções foram utilizadas no volume de $10 \mathrm{ml}$, duas vezes ao dia, por 1 minuto. No quinto dia, determinava-se o índice de placa (TURESKY et al.), bem como o de pigmentação (SHAW; MURRAY). $O$ índice de placa e os escores médios de placa foram maiores para a solução salina (aproximadamente 5,3 ) e menores com o uso da solução de clorexidina (aproximadamente 2,8), destacando essa substância como a mais efetiva contra a nova formação de placa. A solução de triclosan, veio a seguir, com resultados significantemente melhores que os da sanguinarina. Os autores relataram efeitos colaterais, como sensação de ardência e erosão na mucosa bucal, apenas com a solução que continha os produtos naturais.

COLLAERT et al. ${ }^{19}$ (1992) procuraram comparar o efeito de bochechos com o delmopinol $0,2 \%$ e gluconato de clorexidina $0,2 \%$, sobre o desenvolvimento da placa dentária e contagem microbiológica em 45 voluntários, entre 18 e 40 anos de idade. 0 estudo durou 6 semanas, 
sob um modelo duplo-cego, paralelo. Durante as duas semanas iniciais, os participantes, primeiramente, receberam profilaxia profissional e a seguir, instruções sobre a higiene bucal, o que resultou em gengiva clinicamente saudável. No período seguinte, denominado placebo, executou-se nova profilaxia profissional e durante duas semanas suspenderam-se todas as medidas de higiene bucal, aplicando-se $2 \mathrm{ml}$ de uma solução placebo nos dentes, duas vezes ao dia. Seguiu-se novo período com divisão dos pacientes em 2 grupos, os quais, após nova profilaxia profissional, utilizaram uma das soluções ativas. Os bochechos foram realizados com $10 \mathrm{ml}$ de gluconato de clorexidina $0,2 \%$ ou delmopinol $0,2 \%$ por 1 minuto, duas vezes ao dia, durante duas semanas, com suspensão da higiene bucal habitual. $O$ índice de placa utilizado foi o de TURESKEY et al. e a avaliação da presença de pigmentação dentária extrínseca foi feita através de fotos coloridas, no final do período placebo e do período de bochechos. Para a avaliação microbiológica, foram coletadas amostras de saliva estimulada no final do período placebo e no dos bochechos. Os bochechos com gluconato de clorexidina inibiram o acúmulo de placa de forma estatisticamente significante, com uma redução de $88 \%$ em sua extensão na superfície vestibular, quando comparados com os da solução placebo, sendo observadas menos placas na superfície vestibular dos caninos e prémolares. O gluconato de clorexidina produziu significantemente menores índices que o delmopinol. Um total de $76 \%$ das superfícies, no grupo da clorexidina, apresentou escore de placa 0 ou 1 , contra $18 \%$ do grupo do delmopinol. A pigmentação marrom escura evidenciou-se apenas no grupo da clorexidina e 5, dos 21 participantes, relataram uma sensação 
anestésica passageira na mucosa bucal. Nos resultados microbiológicos não existiu diferença significante entre o placebo e o delmopinol, nas contagens dos microrganismos. O número de estreptococos mutans, no grupo da clorexidina, mostrou uma redução estatisticamente significante, quando comparada ao do grupo placebo. Nesse estudo, a solução de gluconato de clorexidina mostrou-se superior em sua habilidade de reduzir placa supragengival, porém há comprometimento estético devido à pigmentação que ocasiona.

JOYSTON-BECHAL et al. $^{50}$ (1992) desenvolveram um estudo com o objetivo de avaliar o efeito de um programa preventivo sobre a incidência de cárie e sobre o nível de estreptococos mutans e lactobacilos, em pacientes submetidos à radioterapia de cabeça e pescoço. Participaram 43 voluntários, entre 16 e 84 anos, que foram examinados uma semana antes da radioterapia e, uma vez por semana, durante 4 semanas de tratamento. 0 retorno para novos exames ocorreu $6,8,12,26,40$ e 52 semanas após o tratamento. O programa preventivo consistiu de bochechos duas vezes por dia, com $10 \mathrm{ml}$ de uma solução contendo clorexidina $0,2 \%$, diluída 1:1 em água, usada antes, durante e após 4 semanas da radioterapia. Ao final, decorridas 8 semanas, substituiu-se a solução por outra contendo fluoreto de sódio 0,05\%, uma vez ao dia. Amostras de saliva foram coletadas da língua e quando os níveis de estreptococos mutans excediam $2 \times 10^{5} \mathrm{UFC} / \mathrm{ml}$, um gel contendo $1 \%$ de clorexidina foi aplicado nos pacientes, por 5 minutos, diariamente, antes de dormir, por 14 dias. Registraram-se o CPOD e CPOS, a placa foi avaliada segundo QUIGLEY; HEIN e o sangramento gengival também foi anotado. As amostras de saliva não estimulada, do 
dorso da língua, foram obtidas no início, 2, 4, 6, 12, 24, 40, e 52 semanas após o tratamento. Nos 25 pacientes que completaram 0 programa ocorreram 3 novas cáries, após 12 meses. 0 índice de placa reduziu de 2,22 no início para 1,75 em 6 meses e 1,8 em 12 meses, sendo a redução estatisticamente significante. Não houve redução significante no nível de estreptococos mutans, no início, durante a radioterapia e após 4 semanas, nem tampouco aumento no decorrer do estudo. Nove pacientes necessitaram utilizar o gel de clorexidina, para manter um nível baixo dos microrganismos. Os níveis de lactobacilos aumentaram na radioterapia e assim permaneceram. Existiu uma melhora significativa na saúde gengival em 6 e 12 meses de acompanhamento. Os pesquisadores concluíram que o regime de utilização de clorexidina e flúor, empregado nesse estudo, pode ser recomendado para o controle de cárie neste grupo de indivíduos, altamente susceptíveis.

No estudo desenvolvido por BINNEY; ADDY; NEWCOMBE ${ }^{12}$ (1992), os autores procuraram verificar a ação de alguns produtos para bochechos e de um dentifrício. A pesquisa desenvolveu-se em 6 períodos de 5 dias cada um, de forma cruzada e cega, sendo a placa avaliada segundo TURESKY et al. e ADDY et al. Os participantes, 18 pacientes entre 20 e 29 anos, apresentaram alto padrão de higiene bucal e saúde gengival. No princípio de cada regime (dia 1 ) executou-se a profilaxia profissional e em seguida iniciou-se o esquema de bochechos. Todas as soluções foram utilizadas com $10 \mathrm{ml}$ de volume por 1 minuto, duas vezes ao dia, com abstenção das medidas de higiene bucal de rotina. Os produtos analisados, um em cada período, foram: perborato de sódio; gluconato de clorexidina $0,2 \%$; solução salina $0,9 \%$ (controle); Plax; 
cloreto de cetilpiridínio 0,05\% com fluoreto de sódio 0,05\% e um dentifrício contendo fluoreto de sódio e monoflúorfosfato de sódio. Um período de 72 horas foi empregado entre cada período da pesquisa, quando os pacientes retornavam às suas medidas de limpeza bucal. Todos os participantes realizaram as 6 etapas, não sendo reportado ou observado nenhum efeito adverso. $O$ índice de TURESKY et al., ao final do tratamento com clorexidina, foi de 1,60 , sendo o menor valor verificado com redução estatisticamente significante em relação à solução controle e as outras substâncias. Segundo os autores, os achados foram pertinentes com os valores das respectivas soluções como adjuntas da higiene bucal.

BRECX et al. ${ }^{16}$ (1993) procuraram comparar o efeito do Meridol (solução de amina fluoretada com 125 ppm de flúor e fluoreto estanoso com 125 ppm de flúor, contendo $5 \%$ de etanol e 0,025\% de aspartame), clorexidina $(0,2 \%$ de gluconato de clorexidina contendo $5 \%$ de etanol) e de uma solução placebo, sobre o desenvolvimento da placa dentária. A amostra constou de 36 estudantes, entre 21 e 36 anos de idade, que numa fase de pré-tratamento receberam profilaxia profissional e foram instruídos a realizarem a higiene bucal de forma usual, por duas semanas, a fim de padronizar o estado gengival. No início da pesquisa, os dentes foram novamente polidos e os pacientes realizaram bochechos duas vezes ao dia, por 1 minuto, com $10 \mathrm{ml}$ de uma das soluções, durante 3 meses, sendo mantidos os hábitos de higiene bucal usuais. 0 acúmulo de placa foi anotado de acordo com os critérios de SILNESS; LÖE no $14^{\circ}$ dia do mês inicial, e após 1,2 e 3 meses de bochechos. 0 índice de pigmentação foi baseado numa modificação do índice de LANG; 
RABER. Os escores do índice de placa aumentaram do início até um mês no grupo que utilizou solução placebo e manteve-se em torno de 1,0 durante o período remanescente do trabalho. Durante os 3 meses, os escores foram menores para o grupo da clorexidina e do Meridol ficando ao final em 0,27 para a clorexidina e 0,55 para o Meridol. O grupo da clorexidina mostrou valores significantemente menores no mês 2 comparado ao do Meridol, e esta diferença diminuiu no mês 3. 0 índice de placa decresceu no primeiro mês de uso da clorexidina e manteve-se semelhante até o final do experimento. Com relação às manchas nos dentes, as 3 soluções ativas apresentaram esse efeito adverso, porém o grupo da clorexidina apresentou escores mais altos. Ao final do estudo, 0 escore médio de placa com o gluconato de clorexidina foi similar ao de outras pesquisas, onde não foi permitida a higiene bucal, assim como de outras investigações, quando esse hábito foi permitido. Isto sugere, segundo os autores, que quando a clorexidina é usada em um modelo clinicamente livre de placa, a higiene bucal individual não causa efeito adicional.

SULLIVAN et al. ${ }^{100}$ (1993) realizaram um trabalho com 34 crianças, menores de 16 anos, com diagnóstico de leucemia aguda. Os pacientes receberam quimioterapia citotóxica e foram acompanhados por um período de 6 meses a 1 ano para determinação das mudanças na microbiota bucal, sendo examinados antes do tratamento e em intervalos mensais. Amostras de saliva foram coletadas com a finalidade de se avaliar os níveis de estreptococos mutans e candida. Um tratamento profilático foi empregado concomitantemente com as crianças realizando bochechos com solução de gluconato de clorexidina $0,2 \%$ e nistatina 
(100.000 unidades $/ \mathrm{ml})$, 4 vezes ao dia. Os testes de sensibilidade mostraram que os estreptococos mutans foram mais sensíveis à droga citotóxica daunorubicina e que a mesma foi provavelmente a responsável pela queda de sua contagem. Os bochechos com clorexidina usados como rotina afetaram a microbiota bucal e também foram responsáveis pela queda dos estreptococos mutans na boca, durante o estudo. Os autores concluíram que o uso da medicação profilática com clorexidina e um antifúngico foram importantes fatores na redução da infecção bucal e devem ser usados de rotina em crianças que recebem quimioterapia em diferentes centros.

JENKINS et al. $^{48}$ (1994) avaliaram a magnitude e a duração do efeito de bochechos com agentes antimicrobianos. O estudo foi duplo-cego, cruzado, no qual participaram 14 voluntários, entre 20 e 39 anos de idade, utilizando 7 soluções sendo 6 comerciais e uma placebo: solução salina (controle); triclosan 0,03\%; cloreto de zinco; Listerine; duas soluções contendo cloreto de cetilpiridíneo e gluconato de clorexidina $0,2 \%$. No dia do teste, a higiene bucal foi suspensa e uma amostra de saliva não estimulada foi coletada, pela manhã. Os bochechos foram executados uma vez ao dia, com o volume recomendado do produto, por 60 segundos com obtenção de amostras de saliva após 30, $60,180,300$ e 420 minutos dos mesmos. Um intervalo de no mínimo 5 dias foi dado entre os bochechos com cada produto. Todos os voluntários completaram o estudo e efeitos colaterais não foram detectados. Todos os agentes proporcionaram uma queda na contagem de microrganismos salivares e esta foi maior para a clorexidina $0,2 \%$ e menor para a solução salina. A queda maior ocorreu dentro dos 30 minutos e nos demais 
tempos, as soluções com cloreto de cetilpiridíneo, Listerine e triclosan produziram contagens similares até o tempo de 300 minutos ( 5 horas) e no tempo de 400 minutos ( 7 horas), elas aumentaram em direção ao valor inicial. O cloreto de zinco provocou queda apenas nos 30 minutos, com retorno progressivo aos valores iniciais nas demais contagens. A clorexidina manteve o valor baixo até o tempo de 300 minutos com suave aumento em 420 minutos, porém com número próximo ao encontrado no 30 minutos iniciais. Houve diferença significante entre os tratamentos com a solução salina, com exceção de uma das soluções de cloreto de cetilpiridíneo nos 30 minutos e Listerine nos 420 minutos. 0 decréscimo na contagem das colônias com a clorexidina foi significantemente maior do que com as outras soluções, sendo a única exceção, nos 30 minutos, com o cloreto de zinco. Os autores concluíram que os resultados correlacionam-se com os efeitos clínicos das substâncias sobre a inibição da placa.

HASE et al. ${ }^{41}$ (1995), num estudo duplo-cego com 57 indivíduos de 18 a 60 anos, avaliaram a formação de placa frente a duas soluções. $O$ experimento transcorreu em período de 4 semanas, no qual os participantes foram divididos em 3 grupos que utilizaram uma das soluções: digluconato de clorexidina $0,2 \%$ (grupo I), delmopinol 0,2\% (grupo II) ou placebo (grupo III). Os participantes bochecharam com 10 $\mathrm{ml}$ da solução por 30 segundos, duas vezes ao dia, após escovação dentária, sem supervisão. Previamente ao primeiro bochecho, realizou-se profilaxia profissional e os pacientes foram instruídos a escovarem seus dentes sem o dentifrício. Nos dias 0, 14 e 28 que corresponderam ao início, segunda e quarta semanas, respectivamente, um único 
examinador avaliou a placa, utilizando o índice de SILNESS; LÖE. Coletou-se também toda placa dos dentes do lado direito para que fosse pesada. Na análise do índice de placa, os grupos I e II apresentaram redução estatisticamente significante no final do estudo. A redução total deveu-se, principalmente, à diminuição nos sítios interproximais. A solução de digluconato de clorexidina reduziu em todas as áreas os escores de placa em maior extensão (próximo de zero) que o delmopinol $0,2 \%$, e isso também foi verdadeiro para o peso de placa; porém causou maior pigmentação nos dentes e língua, havendo ainda relatos de sensação anestésica passageira na mucosa bucal. A solução de digluconato de clorexidina foi a que apresentou o maior número de dados na referência de sabor "muito ruim". Os autores concluíram que, neste modelo de estudo, bochechos com digluconato de clorexidina $0,2 \%$ como um suplemento da higiene bucal, seguida da profilaxia profissional, resultou em menor formação de placa.

ADDY et al. ${ }^{5}$ (1995) procuraram determinar se um agente co-polímero antiadesivo preveniria a pigmentação de dentes e mucosas por uma solução contendo clorexidina. Associado a isso, foi investigado o potencial de indução de manchas de um produto fenólico para bochechos (Listerine). O estudo teve um modelo cego, cruzado, ao acaso e comparou as seguintes soluções: agente antiadesivo, clorexidina 0,2\%, clorexidina 0,2\% com agente antiadesivo, Listerine e água. Participaram 15 voluntários que, previamente ao período experimental e durante 0 mesmo, foram orientados a escovarem a língua por 30 segundos, duas vezes ao dia. Ao primeiro dia, os dentes foram corados e em seguida receberam profilaxia profissional, seguido de um bochecho com $10 \mathrm{ml}$ de 
chá preto morno. O regime adotado para as soluções de clorexidina foi de $10 \mathrm{ml}$ de bochecho, por 1 minuto e para a Listerine $20 \mathrm{ml}$ de solução, por 30 segundos. Cada solução foi utilizada por 4 dias, sendo que neles, os pacientes foram estimulados a beberem no mínimo, 5 copos de chá por dia. Um intervalo de no mínimo 72 horas foi dado entre cada fase. No quarto dia, após o último bochecho, foi feita uma avaliação clínica da pigmentação, bem como de qualquer outro efeito colateral observado. Utilizou-se o índice de SHAW; MURRAY, cujos critérios foram verificar a pigmentação da superfície vestibular dos incisivos superiores e inferiores, caninos e pré-molares e também fez-se uma avaliação subjetiva da intensidade de pigmentação. A língua também foi avaliada de forma subjetiva.

A clorexidina $0,2 \%$ causou maior pigmentação do que a solução de Listerine. Não houve diferença significante entre os grupos que bochecharam com antiadesivo, antiadesivo e clorexidina e o controle, embora tenha existido menor pigmentação das soluções que continham o antiadesivo que a solução controle. Em ordem decrescente, o potencial de pigmentação das soluções foi: clorexidina 0,2\%; Listerine; soluções com o antiadesivo e controle. Em relação à pigmentação da língua, a clorexidina $0,2 \%$ provocou maiores registros não existindo diferença significante entre a solução controle e as que continham o antiadesivo. Como para os dentes, houve uma tendência à menor pigmentação das soluções com antiadesivo comparadas à solução controle. Os autores concluíram que os bochechos com clorexidina têm potencial de causar pigmentação nos dentes e língua, além disso, o estudo mostrou com maior evidência que a dieta teve um papel importante nesse processo. 
SMITH et al. $^{97}$ (1995) compararam bochechos com clorexidina nas concentrações $0,12 \%$ e $0,2 \%$ (controle positivo) e uma solução controle de formulação idêntica a de $0,12 \%$, sem a substância ativa (controle negativo), sobre o acúmulo de placa. O teste clínico foi duplo cego, cruzado, com duração de 4 dias cada, envolvendo 24 voluntários entre 20 e 50 anos de idade. Os grupos que utilizaram a solução de clorexidina $0,12 \%$ e seu controle negativo, bochecharam com $15 \mathrm{ml}$ por 60 segundos, duas vezes ao dia e o que utilizou a concentração de $0,2 \%$ bochechou com $10 \mathrm{ml}$ por 60 segundos, duas vezes ao dia. Entre cada período teste houve um intervalo de 10 dias sem bochechos, quando os pacientes receberam escova e dentifrício fluoretado, padronizados. No primeiro dia de cada período experimental executou-se a profilaxia profissional e os participantes foram orientados a suspender a higiene bucal. Para a verificação da presença de placa, empregou-se o índice de TURESKEY et al., no início e final de cada fase. Nenhum efeito colateral foi registrado em relação ao sabor amargo ou ao distúrbio do paladar verificados pelos voluntários ou no exame clínico. As preparações de clorexidina $0,2 \%$ e $0,12 \%$ resultaram acúmulo de placa significantemente menor, com escore médio de 2,05 e 2,10, respectivamente, quando comparadas ao controle negativo com escore médio de 3,02, com efeitos similares entre si. Os resultados confirmaram uma considerável ação na inibição de placa dos bochechos com clorexidina e que a concentração a 0,12\%, disponível no mercado, possui atividade sobre a placa.

A pesquisa de MORAN et al. $^{77}$ (1995) teve como meta avaliar o efeito de bochechos com soluções oxidantes e clorexidina sobre 
as contagens bacterianas salivares e formação de placa dentária. 0 estudo foi cruzado, em 4 etapas de 4 dias cada, com participação de 16 voluntários, escolhidos ao acaso e com elevado padrão de higiene bucal e saúde gengival. As soluções testadas foram: clorexidina 0,2\%, peroxiborato de sódio, peroxicarbonato de sódio e solução salina $0,9 \%$. Os bochechos realizados com a primeira e quarta solução seguiram o regime de $10 \mathrm{ml}$ de solução, duas vezes ao dia, por 30 segundos e para as outras duas soluções, apenas o volume foi diferente consistindo de 30 $\mathrm{ml}$, devido à dissolução em água. No primeiro dia de cada fase, os participantes receberam profilaxia profissional e suspenderam os hábitos de higiene habitual, iniciando os bochechos. No quinto dia, realizou-se 0 índice de placa segundo TURESKY et al. e ADDY et al. Os intervalos entre as etapas foram de no mínimo 2 dias e meio, quando os pacientes retornavam à higiene bucal de rotina. Para a avaliação microbiológica, o mesmo modelo foi utilizado, no qual os voluntários executavam um único bochecho com os regimes descritos acima, sendo a saliva não estimulada obtida antes do bochecho e 30,60, 180, 300 e 420 minutos após os mesmos. No índice de placa (TURESKY et al.) bem como na área de placa (ADDY et al.), os menores valores foram vistos no grupo da clorexidina, sendo de 0,582 e 0,135, respectivamente. Para as soluções oxidantes do segundo e terceiro grupo, os valores foram respectivamente: 0,627; 0,339 e 0,$782 ; 0,349$. Esses dados revelaram que os bochechos com solução ativa foram melhores e estatisticamente significantes que a solução salina e que a clorexidina foi a solução mais efetiva. Os resultados das contagens bacterianas evidenciaram uma pequena redução nos números e as soluções oxidantes foram melhores que a 
solução salina até o tempo de 180 minutos e a partir daí, tornaram-se similares. A clorexidina produziu reduções de destaque ao redor de $90 \%$ que foram mantidas no mesmo nível até o período de 7 horas. Entre os tratamentos, a clorexidina foi a única que causou redução estatisticamente significante. Os autores concluíram que os bochechos oxidantes podem inibir a formação de placa, porém não por um efeito antibacteriano direto, mas por algum outro mecanismo.

HILDEBRANDT $^{44}$ (1996) estudou o efeito do tratamento repetido, por 7 noites consecutivas, com clorexidina na supressão de estreptococos mutans salivares, em pacientes que apresentavam elevado número dessa bactéria. Procurou também documentar a ocorrência de possíveis efeitos colaterais e verificar se as reclamações se intensificaram ou não com esse tratamento. Colaboraram 22 pacientes com número de Unidades Formadoras de Colônias maior ou igual a $10^{5}$, designados ao acaso para um grupo experimental e um controle ou cruzado, sem fiscalização da dieta ou da higiene bucal. Amostras de saliva foram coletadas imediatamente após o tratamento e 1 e 3 meses depois do mesmo. Um dispositivo bucal foi revestido internamente com um de 2 vernizes, sendo um com um diacetato de clorexidina (dose aproximada de $40 \mathrm{mg}$ ) e outro sem clorexidina. Os pacientes utilizaram o dispositivo bucal por essas noites, enquanto dormiam, com um intervalo mínimo de uma semana entre os tratamentos. Os participantes do grupo controle subseqüentemente, também utilizaram o dispositivo com clorexidina (grupo cruzado). Os pacientes que utilizaram o aparelho com a clorexidina registraram uma redução na média de estreptococos mutans 
salivares durante as 3 coletas de saliva pós-tratamento. No grupo controle, não ocorreram mudanças significantes nesses níveis.

$$
\text { ELWORTHY et al. }{ }^{27} \text { (1996) procuraram comparar a }
$$
substantividade antimicrobiana de produtos de higiene bucal e formulações experimentais através da contagem de bactérias salivares. Vinte voluntários fizeram parte do estudo, cruzado, cego, que envolveu 10 etapas de 7 horas de contagem bacteriana, após o uso das substâncias. As formulações ou produtos selecionados foram: gluconato de clorexidina $0,12 \%$, 4 soluções contendo cloreto de cetilpiridíneo com ou sem fluoreto de sódio e/ou álcool, uma solução controle sem cloreto de cetilpiridíneo, 2 dentifrícios com ou sem fluoreto estanoso e água (solução placebo). O bochecho foi realizado com $15 \mathrm{ml}$ de solução por 60 segundos. No dia do procedimento, os pacientes suspenderam a higiene bucal e amostras de saliva não estimulada foram obtidas imediatamente antes e 30,60, 180, 300 e 420 minutos após os bochechos. Um período de no mínimo 7 dias foi intercalado entre cada solução. Todos os bochechos, exceto a água e o controle sem o cloreto de cetilpiridíneo produziram um decréscimo significante nas contagens, em relação ao início, no tempo de 30 minutos. A solução de clorexidina demonstrou o maior efeito com o máximo de eficácia entre 3 e 5 horas e permaneceu com valores bem abaixo das outras substâncias até às 7 horas. As formulações de cloreto de cetilpiridíneo tiveram efeitos similares em termos da magnitude de redução das contagens e duração do efeito. 0 dentifrício com ou sem fluoreto estanoso também teve comportamento similar acima do período de 5 horas, após o qual, reverteu às contagens iniciais. Os autores concluíram que em relação à substantividade, as 
substâncias foram ordenadas da seguinte forma decrescente: clorexidina, dentifrício com fluoreto estanoso e seu controle, cloreto de cetilpiridíneo e seu controle e água. Se essas formulações exercerem sua atividade inibitória sobre a placa dentária, conforme sua ação antimicrobiana neste estudo, poderiam produzir a mesma ordem de inibição química relativamente às suas substantividades.

HASE et al. ${ }^{42}$ (1998) verificaram, em um estudo clínico, duplo-cego, paralelo, ao acaso e com duração de 6 meses, o efeito do digluconato de clorexidina $0,2 \%$ e do delmopinol $0,2 \%$, sobre a placa dentária e microbiota salivar. Participaram 68 adultos que foram divididos em 3 grupos, sendo 2 com uma das substâncias ativas e um, placebo. As soluções foram bochechadas com $10 \mathrm{ml}$ por 60 segundos, duas vezes ao dia, durante 6 meses. Antes do início do esquema de trabalho, os pacientes receberam profilaxia profissional e as avaliações microbiológicas ocorreram no início do estudo, após 3 e 6 meses, bem como aos 9 meses (3 meses posteriores ao final do estudo). Os microrganismos selecionados para avaliação foram os relacionados à gengivite/periodontite e à cárie dentária, sendo estes últimos os estreptococos mutans e lactobacilos. Para isso, amostras de placa foram obtidas das superfícies vestibular e lingual dos dentes 14 e 16 e amostra de saliva estimulada. Para determinação dos estreptococos mutans utilizou-se o teste DENTOCULT SM. Os resultados, nas amostras de placa, registraram que os bochechos com solução ativa reduziram a contagem total de microrganismos aeróbios e anaeróbios. Para a clorexidina a redução foi estatisticamente significante já nos 3 meses, e para o delmopinol após 6 meses. As duas soluções ativas reduziram o número 
de estreptococos mutans, significantemente, comparadas com o placebo, durante os 3 e 6 meses e este decréscimo permaneceu constante para a clorexidina, no exame realizado 3 meses após o término do esquema. As contagens, nas amostras de saliva, mostraram que durante os 6 meses nenhuma mudança significativa foi obtida nos 3 grupos, ficando as contagens com valores médios de $10^{8} / \mathrm{ml}$ de saliva. Para os estreptococos mutans houve diferença estatisticamente significante entre os 3 grupos, sendo para a solução de clorexidina $0,2 \%$, o valor de $<10^{5} / \mathrm{ml}$ de saliva, predominante nos 3 registros e para o delmopinol, esse resultado apareceu aos 6 meses. Os autores relataram que das substâncias ativas a clorexidina mostrou melhor efeito residual, nos grupos microbiológicos estudados, tanto para a placa como para a saliva.

\section{2 - Clorexidina Associada ao Flúor}

O efeito da combinação da clorexidina e flúor foi avaliado em poucos trabalhos, especialmente, na forma de bochechos $47,49,69,70,74$, 98, 99. Entretanto, algumas investigações "in vitro" têm demonstrado a atuação dessas substâncias associadas sobre os estreptococos mutans e esmalte dentário ${ }^{66,67,69}$.

LUOMA $^{66}$ (1972) verificou os efeitos da combinação da clorexidina e flúor sobre o conteúdo de potássio, sódio, fósforo e a produção ácida de Streptococcus mutans K-1. Para o estudo foram utilizados água destilada (controle), acetato de clorexidina (100 ppm) e fluoreto de sódio (400 ppm). Essas concentrações foram diluídas em até 
8 vezes. O flúor sozinho, em $50 \mathrm{ppm}$, reduziu significantemente o potássio celular bem como o fósforo total, na ausência e presença de sacarose, enquanto a clorexidina sozinha, a 12,5 ppm, inibiu ligeiramente o acúmulo dos 2 elementos ou sua concentração nas células na ausência de energia. Quando usado em associação, mantida constante a concentração de clorexidina em 12,5 ppm e o flúor em 25 ppm ativaram no máximo o acúmulo de fósforo e potássio pelas células. Mas com o aumento da concentração de flúor, os valores foram decrescendo até que em 100 ppm, eles ficaram abaixo dos valores do controle. $O$ tratamento com 50 ppm de flúor sozinho teve pouca influência sobre a produção ácida, já com a clorexidina sozinha, em 12,5 ppm, houve redução apreciável. Quando a clorexidina e flúor estavam presentes na concentração de 25 ppm ou mais, o efeito inibitório foi maior do que com a clorexidina sozinha. Com 50 ppm de ambas as substâncias, houve inibição ácida completa.

LUOMA et al. ${ }^{69}$ (1973) procuraram verificar a redução da solubilidade do esmalte e do desenvolvimento de placa por soluções contendo fluoreto de sódio $0,05 \%$ associado ou não ao acetato de clorexidina 0,022\%, em pH 5,8. No estudo sobre a influência na placa dentária, participaram 20 estudantes de Odontologia que foram orientados a escovarem os dentes cuidadosamente pela manhã e posteriormente suspenderem a higiene bucal por 4 dias. Receberam então, 10 tabletes de sacarose, com 2 gramas cada, e foram instruídos para utilizá-los em intervalos regulares durante cada dia. O programa consistia de bochechos duas vezes ao dia, com $10 \mathrm{ml}$ de solução por 1 minuto. A solução controle foi água destilada. Todos pacientes 
participaram de 3 etapas, com intervalo de 1 semana entre elas e também foram informados sobre o conteúdo das soluções testadas, porém não sabiam qual estariam utilizando na etapa. Para determinação da quantidade de placa, toda placa foi removida de um dos lados da boca com exclusão dos terceiros molares, determinando-se no outro lado o índice de placa de QUIGLEY; HEIN. Um experimento adicional foi feito apenas para comparar o efeito da combinação clorexidina/flúor com o efeito da clorexidina sozinha sobre o desenvolvimento da placa, só que no $\mathrm{pH} 6,0$. Um total de 8 pacientes fizeram parte desse experimento em condições similares às do trabalho anterior. Os resultados, do primeiro trabalho, revelaram que o fluoreto de sódio sozinho não influenciou no índice de placa, reduzindo porém, significantemente, a massa de placa em $41 \%$. A combinação das substâncias reduziu o índice de placa em $44 \%$, sendo estatisticamente significante em relação as demais soluções. A massa de placa após esses mesmos bochechos foi $38 \%$ menor do que após solução controle, porém não diferiu estatisticamente da solução de fluoreto de sódio 0,05\%. O experimento adicional mostrou que nem o índice de placa nem a massa de placa foram essencialmente modificados pelo uso simultâneo do flúor e clorexidina $(2,3$ e $175 \mu \mathrm{g}$, respectivamente) quando comparados à clorexidina sozinha (2,1 e 147 $\mu \mathrm{g}$, respectivamente). Existiu uma tendência a maiores escores quando do uso da solução combinada que com o da clorexidina sozinha, porém, não significante.

LUOMA $^{67}$ (1975) investigou a participação do fosfato bacteriano na troca e re-endurecimento do esmalte e as modificações ocorridas na presença de flúor, clorexidina e propanol. As cepas FA-1 e 
K-1 de Streptococcus mutans foram utilizadas e incubadas em solução tampão, pH 5,9, inicialmente saturada ou supersaturada com grânulos de esmalte de incisivos permanentes bovinos, formando um sistema esmalte-bactéria. A concentração final do fluoreto de sódio e do gluconato de clorexidina foi de $50 \mathrm{ppm}$, empregados no sistema com o volume de $10 \mu \mathrm{l}$. O flúor sozinho e em associação com propanol ou clorexidina aumentou a remoção de fosfato bacteriano pelo esmalte. Durante a incubação prolongada da bactéria em esmalte amolecido, o flúor, especialmente junto com a clorexidina, causou um marcante reendurecimento da superfície do esmalte $(70 \%)$ e uma elevação do $\mathrm{pH}$ para 8,3 .

O efeito da combinação de clorexidina e flúor administrada na água de beber, em hamsters, sobre a prevenção de placa e cárie, foi verificado por BRAYER; GEDALIA; GOVER ${ }^{15}$ (1977). Os animais foram divididos em 4 grupos: grupo 1, controle, recebia 0,5 ppm de flúor; grupo 2, clorexidina 0,2\%; grupo 3, 5 ppm de flúor e grupo 4, simultaneamente clorexidina 0,2\% e flúor $5 \mathrm{ppm}$. Metade dos animais, de cada grupo, recebia uma dieta padrão e a outra metade, uma dieta formadora de cárie e placa. Após 50 dias de trabalho, os animais foram pesados e sacrificados. Os molares da maxila e mandíbula receberam escores de placa, empregando-se eritrosina $1 \%$, e a extensão dessa placa foi anotada das superfícies vestibular e lingual, dando-se valor de 0 a 3 . Os escores de cárie foram registrados em relação à quantidade de substância dentária destruída. A média do índice de placa do grupo que recebeu flúor não foi significantemente menor que a do controle e nos grupos que utilizaram clorexidina com ou sem flúor, os índices foram 
significantemente menores que os resultados dos 2 outros grupos, mas não estatisticamente diferentes entre si. Os valores no grupo 2 foram de 0,58 com a dieta padrão e 0,40 com a dieta cariogênica e no grupo 4, 0,78 com a dieta padrão e 0,47 com a dieta cariogênica. 0 grau de cárie dos grupos experimentais foi significantemente menor que o do grupo controle, durante o regime com dieta cariogênica. A diferença, na incidência de cárie, entre os grupos experimentais não foi significante e nenhum efeito cariostático aditivo no grupo que utilizou clorexidina e flúor foi observado, provavelmente devido à baixa concentração de flúor na água de beber. Segundo os autores, o estudo confirmou o efeito anticariogênico e antiplaca da clorexidina associada ao flúor, em baixas concentrações, com dieta cariogênica.

LUOMA et al. ${ }^{70}$ (1978) tiveram como proposta estudar a redução do incremento de cárie e de gengivite em um grupo de 164 escolares, entre 11 e 15 anos de idade, com alto CPOS, que receberam aplicação de clorexidina e flúor. Para as avaliações de cárie, realizaram exames clínico e radiográfico. Os escores de cárie seguiram os critérios de MOLLER; POULSEN e o estado gengival foi avaliado pelo índice de AINAMO; BAY. Posteriormente ao exame inicial, as crianças foram divididas em 4 grupos que receberam orientações de escovação diária, sem dentifrício, sob supervisão, e depois bochechos, por 2 minutos com $10 \mathrm{ml}$ de uma destas soluções: gluconato de clorexidina $0,05 \%$ e fluoreto de sódio 0,044\% (grupo1); fluoreto de sódio 0,044\% (grupo 2) e solução placebo (grupo 3). Um outro grupo de estudantes (grupo 4) não participou do programa e serviu como um controle básico. Executou-se um tratamento restaurador uma vez ao ano e em seguida aplicação de 
fluoreto de sódio $0,2 \%$. Um esquema de motivação foi mantido para permitir corretos hábitos de higiene bucal e dietéticos. Os exames foram repetidos 1 e 2 anos após e os examinadores não sabiam a que grupo pertencia cada estudante. Uma parte dos participantes dos grupos 1, 2 e 3 foi fotografada para observação de pigmentação, após 10 semanas do início do trabalho. Não existiu diferença significante nas médias iniciais do CPOS entre os grupos e, após 2 anos, houve um registro de $53 \%$ na redução do incremento de cárie no grupo da clorexidina associada ao flúor (grupo 1), quando comparado ao grupo controle (grupo 4) e, de $42 \%$, quando comparado ao placebo (grupo 3). Reduções significantes também foram encontradas no grupo que bochechou apenas com o flúor (grupo 2), sendo de 32\%, em relação ao controle. Apenas as cáries de superfícies oclusais não foram reduzidas pela solução combinada (grupo 1), enquanto para as superfícies vestibular/lingual e mesial/distal, essa redução foi de $66,3 \%$ e $73,2 \%$, respectivamente. Com relação ao sangramento gengival, o grupo da clorexidina associada ao flúor teve uma redução no índice de $63 \%$ para $14 \%$ e esta foi estatisticamente significante. Foram detectadas pigmentações castanho-amareladas em alguns dentes no grupo 1 que, em sua maioria, foram bem suaves. Nenhuma pigmentação ou outros efeitos colaterais foram denotados na língua ou em qualquer outra região da mucosa bucal.

O trabalho desenvolvido por LUOMA et al. ${ }^{71}$ (1984) teve por objetivo verificar a eficácia da combinação de clorexidina e flúor na proteção à saúde bucal. Foram utilizados 4 grupos de ratos que tiveram seus molares pincelados, durante 48 dias, com uma das soluções que se seguem: grupo $\mathrm{C}$, água destilada, grupo CXF, solução de clorexidina 
0,05\% e fluoreto de sódio 0,025\%, pH 5,8, grupo CXFS, a mesma solução anterior acrescida de estrôncio (1 grama por litro) e grupo CXFSZ, que continha os mesmos ingredientes da solução anterior mais zinco (1 grama por litro). Cáries de fissura, envolvendo dentina, foram reduzidas em $57 \%$ no grupo CXF e em $68 \%$, no grupo CXFS. 0 tratamento com CXFSZ não reduziu cárie de maneira significante, mas reduziu o acúmulo de placa. Infiltração de células inflamatórias, vascularização e espessura da mucosa bucal foram maiores no grupo CXFSZ. Nos demais, as alterações foram pequenas. Os autores concluíram que a suplementação com solução contendo clorexidina, associada ao flúor e/ou estrôncio, pareceu ser benéfica nas medidas de controle de cárie.

MCDERMID et al. $^{73}$ (1985) avaliaram o efeito do digluconato de clorexidina $0,07 \mathrm{mM}$ ou $0,15 \mathrm{mM}$ e do fluoreto de potássio $4,0 \mathrm{mM}$ ou $8,0 \mathrm{mM}$ sobre a produção ácida de Streptococcus mutans e Streptococcus sanguis. As soluções foram empregadas isoladamente ou em combinação. A clorexidina evidenciou maior ação inibitória sobre S. mutans, enquanto o S. sanguis foi mais sensível ao flúor. As condições de crescimento afetaram a sensibilidade de ambas espécies para as duas substâncias e, em geral, o crescimento celular, no meio com glicose foi mais sensível que no meio com sacarose. Em relação à produção ácida, os $\mathrm{S}$. mutans produziram mais ácido com a glicose e sacarose que o $\mathrm{S}$. sanguis. A associação de $0,15 \mathrm{mM}$ de clorexidina e $8,0 \mathrm{mM}$ de fluoreto de potássio produziu $92 \%$ de inibição na produção ácida no meio com glicose e sacarose. Esse resultado foi obtido tanto no $\mathrm{pH}$ constante quanto no ambiente de queda de $\mathrm{pH}$. Assim a combinação de flúor e 
clorexidina provocou efeito inibitório aditivo sobre a produção ácida, resultando num $\mathrm{pH}$ final maior que com a utilização das substâncias isoladamente.

SPETS-HAPPONEN et al. ${ }^{98}$ (1985) compararam uma possível redução do nível de estreptococos mutans na saliva, assim como a duração desse efeito, em crianças com elevado CPOD, utilizando soluções contendo clorexidina e flúor. O estudo foi de modelo duplo-cego com participação de 31 crianças, com idades entre 8 e 12 anos, que bochecharam com uma das 2 soluções: solução 1, que continha gluconato de clorexidina $0,05 \%$ e fluoreto de sódio $0,025 \%$ e solução 2 , com a mesma composição acima acrescida de cloreto de estrôncio 0,1\%. Os bochechos foram realizados em casa, duas vezes ao dia, por 1 minuto, com $10 \mathrm{ml}$ de solução, após o café da manhã e antes de dormir. Cada fase durou 3 dias, com intervalo de 6 dias entre elas. Realizaram-se 5 coletas de saliva estimulada: a primeira, antes do primeiro bochecho, a segunda após o último bochecho, as terceira, quarta e quinta coletas foram feitas 7, 14 e 21 dias após o último bochecho, respectivamente. 0 índice gengival foi determinado nos mesmos períodos de coleta de saliva, avaliando-se a tendência ao sangramento. $\mathrm{O}$ número médio de Unidades Formadoras de Colônias (UFC) de estreptococos mutans decresceu em $75 \%$ com a solução 1 e em $66 \%$, com a solução 2 . Após os bochechos, 0 número dessas bactérias no grupo que utilizou a solução 1 começou a aumentar e na quarta amostra, esse valor foi $45 \%$ menor que o inicial e na última coleta, $4 \%$ menor. Já para a solução 2 , a quarta coleta registrou um valor de $17 \%$ a menos e na última coleta, $13 \%$ menor que a inicial. A redução foi estatisticamente significante para a solução 1 até a 
quarta coleta e para a solução 2 , até a terceira coleta. A média de sangramento gengival decresceu de $49 \%$ para $26 \%$ nas crianças que utilizaram clorexidina e flúor após o terceiro dia de bochecho e retornou para 43\% após 14 e 21 dias. No grupo que empregou a solução adicionada de estrôncio, esse índice decresceu de $45 \%$ para $37 \%$ após o terceiro dia sem diferença estatística significante. Os autores relataram que a adição de estrôncio na solução não produziu resultados promissores na associação de clorexidina e flúor, sobre o sangramento gengival e sobre a redução de estreptococos mutans salivares.

SPETS-HAPPONEN et al. ${ }^{99}$ (1991) verificaram a possibilidade de prevenir cárie e gengivite pelo uso periódico de bochechos contendo clorexidina e flúor, com ou sem estrôncio. Um total de 243 escolares, com 11 anos de idade e alto CPOD, foi dividido em 4 grupos. $\mathrm{O}$ grupo $\mathrm{C}$ serviu como controle, sem fazer bochecho. $\mathrm{O}$ grupo CX bochechou com uma solução de clorexidina 0,05\%; o grupo CXF utilizou uma solução contendo clorexidina $0,05 \%$ e fluoreto de sódio 0,04\% e o grupo CXFS, uma solução com as mesmas substâncias do grupo anterior acrescida de estrôncio (500 ppm). O programa de bochechos durou 2 anos e 9 meses, sendo que durante os 6 últimos meses da pesquisa, o conteúdo de estrôncio foi para $15 \mathrm{ppm}$. Todas as soluções, assim como os procedimentos, foram administrados dentro de um modelo de estudo duplo-cego. 0 esquema empregado foi de 5 dias a cada 3 semanas seguindo-se as instruções de bochecho com $5 \mathrm{ml}$ de volume, duas vezes ao dia. Avaliou-se o incremento de cárie de acordo com os critérios de MÖLLER; POULSEN, com algumas modificações registrando-se o CPOS e também fizeram-se radiografias interproximais, 
como auxiliares no diagnóstico. O sangramento gengival foi avaliado segundo AINAMO; BAY. Para as contagens salivares de estreptococos mutans e lactobacilos, foi coletada saliva estimulada. O número de estreptococos mutans foi estimado utilizando-se o teste Dentocult-SM. Os exames foram feitos no início, após 1 ano, após 2 anos e no final do experimento (após 2 anos e 9 meses). Também foram feitos exames uma semana após o período dos bochechos ter se completado. Em 2 anos e 9 meses, a média de CPOS nos grupos C, CXF, CXFS e CX foram 3,8; 2,5; 3,5 e 3,4, respectivamente. No grupo CXF, a incidência de cárie foi menor em todo o tempo do estudo sendo, ao final, $36 \%$ menor que no grupo controle. Entretanto, a diferença entre os grupos de solução ativa não foi estatisticamente significante. Com relação ao sangramento gengival, a redução foi de $53 \%$, 52\%, 37\% e $58 \%$ para os grupos C, CXF, CXFS e CX, respectivamente, sem diferença estatisticamente significante. A contagem de lactobacilos não diferiu entre os grupos, embora tenha existido uma tendência para redução no grupo CXF. A contagem de estreptococos mutans permaneceu constante em todos os grupos, no decorrer do estudo, não existindo alteração. Nos grupos com soluções ativas, foram registradas pigmentações dentárias, sendo na maioria dos casos muito suaves ou até imperceptíveis. Os autores concluíram que existiu um direcionamento no sentido de reduzir a incidência de cárie após o uso periódico de clorexidina associada ao flúor sem, entretanto, surtir efeito sobre o sangramento gengival e contagem de mutans na saliva.

JOYSTON-BECHAL; HERNAMAN ${ }^{49}$ (1993) desenvolveram um estudo duplo-cego, com o propósito de testar o efeito de bochechos 
diários com uma solução antimicrobiana sobre a placa dentária e a inflamação gengival. Para este fim, 47 adultos, acima de 18 anos utilizaram uma solução teste contendo clorexidina 0,05\% e fluoreto de sódio $0,05 \%$ pH 6,0 ou uma solução placebo, com a mesma cor e sabor da solução teste, sem as substâncias ativas. Para os bochechos, foram utilizados $10 \mathrm{ml}$ de uma das soluções, duas vezes ao dia, por 30 segundos, sendo mantidos os hábitos de higiene bucal durante as 8 semanas da pesquisa. Os índices utilizados para as avaliações de placa e gengivite foram, respectivamente, o de SILNESS; LÖE e de COWELL et al. sendo o grau de pigmentação verificado nas superfícies vestibulares dos dentes anteriores, de acordo com os critérios de LOBENE. No ínicio do experimento realizou-se uma profilaxia profissional e os exames clínicos. Posteriormente, na quarta semana, verificou-se a execução dos bochechos e na oitava semana fizeram-se os registros finais de placa, gengivite e pigmentação, bem como nova profilaxia profissional e instrução sobre higiene bucal. No ínicio do experimento não existiu diferença estatisticamente significante nos escores de placa e sangramento gengival. Após 8 semanas, apenas o grupo que utilizou a solução teste mostrou uma redução estatisticamente significante tanto para o índice de placa (de 1,1 para 0,45 - 59,09\%) quanto para o gengival (de 0,8 para $0,1-87,5 \%$ ). No grupo placebo, houve redução no sangramento gengival, entretanto, no grupo-teste, esta foi mais marcante ocorrendo diferença estatisticamente significante entre eles. Com relação à pigmentação, o grupo-teste apresentou médias significantemente maiores que o controle após 8 semanas. Os autores concluíram que como um adjunto da higiene bucal, os bochechos 
contendo clorexidina e flúor, têm um efeito inibitório significante sobre a placa dentária e o sangramento gengival.

JENKINS; ADDY; NEWCOMBE ${ }^{47}$ (1993) avaliaram o efeito de bochechos com solução de clorexidina e flúor, como um adjunto na higiene bucal, sobre a placa dentária e a gengivite. A solução ativa continha gluconato de clorexidina $0,12 \%$ e fluoreto de sódio (100 ppm de íon flúor), e a controle, uma fórmula semelhante, porém sem os ingredientes ativos. $\mathrm{O}$ estudo foi duplo-cego, paralelo, por um período de 6 semanas, no qual os voluntários foram distribuídos ao acaso nos dois grupos. Os 102 participantes tinham entre 18 e 60 anos e apresentavam nível mínimo de gengivite, segundo o índice de LÖE; SILNESS. No início da pesquisa registrou-se o índice de pigmentação de SHAW; MURRAY, índice gengival de LÖE; SILNESS e índice de placa de TURESKY et al. Os participantes foram orientados para executarem os bochechos com $15 \mathrm{ml}$ de solução, duas vezes ao dia, por 1 minuto. As escovas dentárias e dentifrícios foram padronizados e nenhuma instrução específica foi dada, exceto a proibição do uso de outro produto, que não o prescrito.

Os pacientes retornaram após 6 semanas, para avaliação de todos os índices e problemas associados ao uso dos bochechos, particularmente pigmentação, que foram anotados através de um questionário. No início, nenhuma diferença estatisticamente significante foi observada entre os grupos, com relação ao índice de placa e gengivite. Após 6 semanas, o índice de placa diminuiu significantemente no grupo com solução ativa sendo de 2,2 para 1,1 (50\%) e no grupo controle de 2,3 para 1,8 (21\%). Observou-se também uma melhora em todos as faces, para ambos os grupos, sendo que no caso do grupo 
controle, a diminuição foi menor na superfície lingual. Em relação ao índice gengival, em todos os sítios, as médias foram menores no grupo da solução ativa. Os dados referentes à pigmentação revelaram que, após 6 semanas, a freqüência foi significantemente maior no grupo que utilizou a clorexidina associada ao fluoreto de sódio (49\%), sendo a superfície lingual dos incisivos inferiores à mais atingida. $A$ intensidade de pigmentação desse grupo foi quase o dobro do grupo controle e esta diferença foi estatisticamente significante. Também a dor e a alteração no paladar foram mais relatados no grupo da solução experimental. Dois terços dos pacientes, que observaram a própria pigmentação dentária, a relataram como ruim ou inaceitável, comparado com nenhum registro, no grupo controle. Em resposta ao questionário, sobre o sabor das soluções, foi evidente a preferência pela solução controle.

Um estudo duplo-cego e cruzado, comparando o efeito de bochechos contendo $0,12 \%$ de clorexidina e uma associação dessa substância com 0,022\% de fluoreto de sódio sobre o acúmulo de placa, foi desenvolvido por MENDIETA et al. ${ }^{74}$ (1994), com a participação de 18 estudantes de Odontologia. O trabalho constou de um período inicial, com duração de 7 dias (de controle), quando não se permitiu a higiene bucal habitual e nem os procedimentos de bochechos. Outras duas etapas de 7 dias foram realizadas, nas quais foram feitos bochechos com $15 \mathrm{ml}$ de uma das soluções por 30 segundos, duas vezes ao dia. Durante toda pesquisa não se permitiu a higiene bucal, realizando-se profilaxia profissional prévia a cada fase. Os índices de placa utilizados foram o de TURESKY et al. e o de SILNESS; LÖE avaliados por um único examinador, ao final de cada período. Após 14 dias, analisou-se a 
possível presença de descamação da mucosa bucal e pigmentação na língua e dentes. Existiu uma diferença na média dos escores de placa, entre o período inicial de controle e os dois períodos de bochecho. As reduções foram estatisticamente significantes para os bochechos com clorexidina $0,12 \%$ e para a associação com o flúor, sendo de $57 \%$ e $48 \%$, respectivamente, na avaliação pelo índice de SILNESS; LÖE. A comparação entre as etapas com substância ativa revelou maior redução de placa pelo índice de SILNESS; LÖE, para o uso do gluconato de clorexidina sem associação, não confirmada pelo índice de TURESKY et al. que não mostrou diferença estatisticamente significante. Pigmentação dentária e no dorso da língua ocorreu com as duas soluções ativas. Os autores relataram que os resultados, "in vivo", sugeriram redução na disponibilidade da clorexidina, quando associada ao flúor em comparação à essa substância sozinha.

TWETMAN; PETERSON ${ }^{103}$ (1993) estudaram a eficácia de um verniz contendo diacetato de clorexidina $1 \%$ e sua associação com outro verniz contendo flúor $0,1 \%$, sobre o decréscimo do nível interdental de estreptococos mutans. Participaram 82 indivíduos, com idades entre 11 e 13 anos, previamente selecionados, de acordo com o escore de cárie e desses microrganismos salivares $\left(\geq 10^{5}\right.$ Unidades Formadoras de Colônias - UFC). Os sítios proximais do primeiro molar permanente e prémolar ou segundo molar decíduo receberam profilaxia e foram isolados para aplicação de 0,1 $\mathrm{ml}$ de um dos vernizes, durante duas semanas, em duas ocasiões. $\mathrm{O}$ número de microrganismos foi avaliado usando o teste Dentocult SM, sendo cultivadas amostras de 4 sítios interproximais de cada indivíduo, na mesma lâmina. Após 48 horas do tratamento, um 
número médio de UFC foi calculado para cada participante com repetição das contagens 1 e 3 meses depois do tratamento. Os resultados não mostraram diferença estatisticamente significante, em relação à cárie entre as crianças, nos dois grupos. No grupo que recebeu a aplicação do verniz contendo apenas clorexidina, 106 de 164 amostras tinham níveis de estreptococos mutans detectáveis no início e 49 exibiram altas contagens ( $\geq 100$ UFC). Os valores correspondentes para o outro grupo foram de 110 e 56, respectivamente. Não existiu diferença estatisticamente significante entre os grupos no início. Ambos vernizes reduziram as contagens bacterianas significantemente após o primeiro mês, em comparação ao início. Após 3 meses da aplicação, entretanto, as contagens retornaram aos níveis iniciais no grupo da clorexidina, enquanto que permaneceram reduzidos significantemente, no grupo da associação. A diferença estatisticamente significante, entre os grupos, ocorreu após os 3 meses. Os autores sugeriram que neste estudo a mistura de vernizes contendo clorexidina e flúor foi significantemente mais efetiva, após 3 meses, na redução de estreptococos mutans na região interdental. Desconhecem se isso tem significância clínica, mas destacam a implementação de outros estudos clínicos para essa evidenciação.

\section{3 - Esteviosídeo}

Apesar do esteviosídeo ter apresentado efeitos anticariogênico $^{22,55,79}$ e antiplaca ${ }^{11,17,84,96,109}$ e não mostrar efeitos 
colaterais $^{1,106}$, poucos foram os estudos encontrados na literatura consultada.

BERRY; HENRY ${ }^{9}$ (1981) utilizaram cepas de S. mutans para metabolizar sacarose, esteviosídeo, glicose e frutose a fim de avaliar o potencial cariogênico do esteviosídeo. O crescimento "in vitro" foi determinado pela turvação através da mensuração da densidade óptica e a produção de ácidos pela monitorização de pH e titulação de ácido total. Cada cepa (AHT, BHT, GS-5, 6715 e LM-7) foi cultivada em atmosfera anaeróbica em meio com glicose, concentrada pela centrifugação e resuspensa até uma densidade óptica de aproximadamente 0,5. O crescimento bacteriano e a produção ácida foram medidos num período de 24 horas. Foi observada redução estatisticamente significante nesses parâmetros, quando o metabolismo do esteviosídeo foi comparado com o da sacarose, glicose ou frutose. A produção de ácido foi significantemente menor para as cepas AHT, BHT e 6715 e, embora mínima, a proporção foi maior nos tipos GS-5 e LM-7 na utilização do esteviosídeo. Embora mínimas, as taxas de crescimento foram maiores nas cepas GS-5 e 6715 . Esses resultados indicam a possibilidade do uso do esteviosídeo como um adoçante natural de menor potencial na promoção de cárie que a sacarose, glicose e frutose.

Com a finalidade de verificar a incidência de cárie em molares de rato, OLIVEIRA et al. ${ }^{79}$ (1985) desenvolveram uma pesquisa envolvendo 50 animais (Rattus norvegicus albinus), distribuídos em 5 grupos de mesmo número. O período experimental constou de 45 dias, quando todos os grupos receberam dieta cariogênica mais uma das substâncias dissolvidas em água destilada, como se segue: grupo I 
(controle); grupo II guaraná a 2\%; grupo III, infusão de folhas secas e pulverizadas de Stévia Rebaudiana Bertoni a 5\%; grupo IV, esteviosídeo a $0,5 \%$ e grupo $V$, guaraná em pó a $2 \%$ e esteviosídeo a 0,5\%. A quantidade de líquido e de ração consumida pelos animais foi avaliada diariamente, assim como examinou-se a influência de cada tratamento nos escores globais de cárie. Os animais do grupo IV apresentaram aproximadamente $69 \%$ de redução nos escores de cárie para o esmalte e $76 \%$ para a dentina superficial, sendo estatisticamente significante, em relação ao grupo controle. A associação do guaraná com esteviosídeo foi o tratamento mais eficaz, reduzindo $81,5 \%$ os escores de cárie em esmalte e $83,2 \%$ os de dentina. Segundo os autores, o fato do esteviosídeo não determinar reações tóxicas visíveis e causar índices de reduções de cárie tão elevados, promete maiores perspectivas de emprego como substituto da sacarose.

Foram avaliados por PINHEIRO et al. ${ }^{84}$ (1987), os efeitos dos extratos de guaraná $(1,5 \%)$, Stévia rebaudiana Bertoni (folhas 1,5\%) e do esteviosídeo, sobre a fermentação e síntese de polissacarídeos extracelulares insolúveis da placa dentária, num estudo "in vitro". Inicialmente coletou-se a placa dentária de crianças escolares que, previamente ao procedimento, executaram um bochecho com água destilada, a fim de remover os restos alimentares. O extrato de guaraná e de Stévia estimularam a fermentação da placa bacteriana com diferença estatisticamente significante em relação ao controle. O esteviosídeo empregado na concentração $0,32 \%$ causou uma suave, mas não significante, diminuição na fermentação. O extrato de Stévia 1,5\% mostrou-se potente inibidor da síntese de polissacarídeos extracelulares 
insolúveis. A solução de esteviosídeo 0,25\%, inibiu de forma estatisticamente significante a síntese de polissacarídeos extracelulares insolúveis em $78 \%$, quando comparada ao controle com água destilada. Os autores relataram que como o esteviosídeo tem baixa solubilidade em água (à temperatura ambiente, aproximadamente $0,4 \%$ ), sua utilização fica limitada em concentrações mais elevadas, restringindo grandemente seu poder de inibição. Eles concluíram que esses produtos naturais apresentam propriedades anticariogênicas e antiplaca que os indicam como auxiliares de medidas preventivas da cárie dentária.

CHEDID $^{17}$ (1990) propôs-se a avaliar os adoçantes esteviosídeo, aspartame, xilitol e sacarina quanto ao seu papel dentro de processos bioquímicos de fermentação e síntese de polissacarídeos extracelulares insolúveis, pela placa dentária colhida da superfície lisa de crianças entre 7 e 11 anos de idade, e pelos S. mutans GS-5 e LM-7 "in vitro". As substâncias foram avaliadas individualmente e em associação com a sacarose nos testes laboratoriais. Para o estudo com as bactérias, $0,1 \mathrm{ml}$ de cultura de 24 horas de S. mutans GS-5 e LM-7 padronizadas segundo o tubo 3 da escala de MacFarland, era inoculada em meio de cultura (BHI-DIFCO), contendo os adoçantes isolados ou em associação com a sacarose e, com a sacarose isolada, servindo como controle positivo. Uma alíquota de $5 \mathrm{ml}$ era retirada para avaliação da síntese de polissacarídeos extracelulares e mantida em estufa a $37^{\circ} \mathrm{C}$ por 24 horas, enquanto alíquotas de $3 \mathrm{ml}$ eram retiradas de 4 em 4 horas para a obtenção da curva de $\mathrm{pH}$. Os resultados obtidos demonstraram que nenhum dos adoçantes estudados foi metabolizado pelos microrganismos da placa dentária nem pelos S. mutans GS-5 e LM-7. Também não 
interferiram na fermentação quando associados à sacarose. Para a síntese de polissacarídeos extracelulares, apenas a associação de sacarose com esteviosídeo inibiu em 45,23\% a produção desse carboidrato pelo S. mutans LM-7 e 56,35\% para a placa dentária. Desta maneira, a autora concluiu que o esteviosídeo e a sacarina apresentaram propriedade antiplaca e devem ser considerados como mais uma medida de controle e prevenção da cárie dentária.

KLEBER $^{55}$ (1990) propôs-se examinar o efeito de soluções contendo esteviosídeo e/ou fluoreto de sódio sobre a formação de cárie dentária, em ratos albinos. Dividiu os animais em 4 grupos, os quais receberam tòpicamente uma das soluções a seguir: água destilada, esteviosídeo 0,5\%, fluoreto de sódio 0,02\% e esteviosídeo 0,5\% associado ao fluoreto de sódio 0,02\%. Cada grupo reunia 24 animais, distribuídos de forma equilibrada de acordo com o peso, sexo e ninhada, sendo pesados no início e final do estudo. Uma dieta cariogênica foi introduzida como alimento e as soluções aplicadas duas vezes ao dia. 0 tratamento durou 10 semanas, quando os ratos foram sacrificados e as mandíbulas e maxilas preparadas para avaliação dos escores de cárie. 0 exame foi executado de acordo com o número e severidade das lesões nos dentes seccionados. Em relação à cárie de superfície lisa, a aplicação tópica do esteviosídeo 0,5\% (grupo 2), causou redução significante de $18 \%$ em relação à água destilada (grupo 1); a solução de fluoreto de sódio $0,02 \%$ (grupo 3 ) inibiu em $26 \%$ e foi, estatisticamente, equivalente ao grupo 2. A combinação das substâncias (grupo 4), registrou maior redução, da ordem de $38 \%$ e foi, estatisticamente significante em relação ao grupo 2, mas não ao grupo 3. Para a cárie de fissura, a redução no 
grupo 2 foi de $6 \%$, não sendo estatisticamente significante em relação ao grupo 1 . O fluoreto de sódio $0,02 \%$ e a associação do mesmo com o esteviosídeo $0,5 \%$ resultaram em inibição de $26 \%$ e $28 \%$, respectivamente, diferindo estatisticamente significante em relação aos grupos 1 e 2 . O esteviosídeo 0,5\% não influenciou de forma significante na severidade das lesões tanto em superfícies lisas como nas fissuras. Já os grupos 3 e 4 exibiram uma extensão significantemente menor nas cáries de superfície lisa (48\% e 54\%, respectivamente) em relação ao grupo da água destilada, mas não entre si. Com relação às lesões de fissura, a severidade foi reduzida em $36 \%$ pela solução de fluoreto de sódio $0,02 \%$ e em $31 \%$ pela solução associada, sem diferença estatística entre as mesmas. $\mathrm{O}$ autor relata que a combinação do fluoreto de sódio e esteviosídeo não trouxe um benefício adicional na redução de cárie de fissura em comparação ao fluoreto de sódio sozinho. Os resultados, segundo o autor, indicam que o esteviosídeo 0,5\% foi moderadamente cariostático e compatível com o flúor, sendo aceitável para uso individual ou em produtos que contenham flúor.

Em outra pesquisa DAS et al. $^{22}$ (1992) testaram a cariogenicidade dos adoçantes naturais esteviosídeo e rebaudiosídeo A. Para tanto, utilizaram ratas albinas prenhas, inoculadas com S. sobrinus 6716-13 (resistentes à estreptomicina $200 \mathrm{mg} / \mathrm{ml}$ ), que receberam água destilada e deionizada e dieta cariogênica 2000. Após 17 dias nasceram 60 ratos sendo a cavidade bucal dos filhotes checada para verificação da presença dessa bactéria e a possível necessidade de reinoculação e nos $18^{\circ}, 19^{\circ}$ e $20^{\circ}$ dias; todos os ratos receberam cultura fresca de $\mathrm{S}$. sobrinus $\left(2.0 \times 10^{3}\right.$ UFC) na água de beber. Os animais foram divididos em 
4 grupos, recebendo todos a dieta basal 2000 com 56\% de maisena. Parte da maisena foi substituída por sacarose, esteviosídeo ou rebaudiosídeo $A$, da seguinte forma: grupo I recebeu $30 \%$ de sacarose (controle positivo); grupo II, 0,5\% de esteviosídeo; grupo III, 0,5\% de rebaudiosídeo $\mathrm{A}$ e grupo IV, nenhuma substituição (controle negativo). A concentração de $0,5 \%$ de esteviosídeo e rebaudiosídeo $A$ foi eleita frente a intensidade do adoçante favorável ao uso em humanos. Os animais permaneceram com essa dieta por 5 semanas, sendo a ingestão de água e o peso controlados. Ao final do experimento os animais foram sacrificados e a placa foi imediatamente coletada de todos os molares e usada para quantificar S. sobrinus nos animais. A presença de cárie também foi avaliada e as amostras de placa analisadas quantitativamente, sendo desconhecida a identidade do grupo para análise. A contagem de S. sobrinus no grupo 1 foi maior que os outros grupos e não houve diferença estatisticamente significante entre os 3 grupos restantes. Os escores de cárie de sulco foram significantemente maiores nos animais do grupo 1, novamente não se observando diferença estatisticamente significante nos outros grupos que apresentaram baixa incidência dessa lesão. Cárie em dentina foi levemente maior, mas não estatisticamente significante no grupo 1 , em comparação com os grupos 2 e 3, e o grupo 4 não apresentou cárie em dentina. Cárie de superfície lisa foi encontrada apenas no grupo 1 . Tanto o esteviosídeo como o rebaudiosídeo $A$, não produziram qualquer reação adversa nos animais e os autores concluíram que os 2 adoçantes naturais não são cariogênicos, sob as condições desse estudo. 
SLAVUTZKY; SCARPINI ${ }^{96}$ (1994) pesquisaram o efeito da solução de estévia, em forma de bochechos, na formação e acúmulo de placa bacteriana, comparada ao efeito de bochechos com sacarose. A amostra constou de 8 alunos de Odontologia e o índice de placa utilizado foi o de SILNESS; LÖE, realizado sempre pelo mesmo examinador. Após raspagem e profilaxia dos dentes, os participantes foram orientados a não realizarem higiene bucal, continuando com seus hábitos alimentares normais, durante o período da investigação. Por 5 dias, efetuaram bochechos 4 vezes ao dia com solução de sacarose $10 \%$, por 1 minuto. Ao término deste período, foi re-avaliado o índice de placa e feita uma nova raspagem e profilaxia profissional dos dentes, com os alunos dando continuidade à alimentação habitual e a não execução da higiene bucal. A segunda fase obedeceu o mesmo protocolo da primeira, só que utilizando solução de estévia $10 \%$. Os bochechos com estévia em $100 \%$ dos casos, determinaram menor formação de placa bacteriana, quando comparados com a sacarose, tendo a placa aparência farinhenta, diferindo no volume e na consistência da placa formada quando dos bochechos com sacarose. Os estudantes relataram a sensação de estar com a boca repleta de placa na utilização da sacarose, e menor presença com o uso da estévia. Na análise do índice de placa, evidenciou-se uma menor capacidade de formação de placa com a estévia, sendo este decréscimo da ordem de $57,82 \%$. Os participantes também relataram um sabor desagradável com esta solução.

O objetivo do trabalho de ROSSONI ${ }^{90}$ (1995) foi testar a cariogenicidade do adoçante comercial STEVITA $®$, que contém na sua composição esteviosídeo e lactose. Sete indivíduos usaram aparelhos de 
acrílico palatinos removíveis contendo quatro blocos de esmalte dentário e utilizaram cada adoçante por períodos de 28 dias. As soluções testes foram: sacarose $17 \%$, STEVITA ${ }^{\circledR} 2 \%$ (esteviosídeo $0,2 \%$ e lactose $1,8 \%$ ), lactose $1,8 \%$ e esteviosídeo $0,2 \%$. Após 28 dias, foram coletadas amostras de placa de dois blocos de esmalte para análise da microbiota cariogênica (estreptococos do grupo mutans e lactobacilos). Observou-se menor crescimento de lactobacilos (média \pm desvio padrão UFC/mg de placa) com esteviosídeo $(0,2 \times 10 \pm 0,3 \times 10)$, do que com os adoçantes lactose $\left(2,43 \times 10^{5} \pm 5,22 \times 10^{5}\right)$ e sacarose $\left(1,4 \times 10^{6} \pm 2,05 \times 10^{6}\right)$. O nível de lactobacilos na presença de STEVITA ${ }^{\circledR}\left(6,48 \times 10^{2} \pm 9,91 \times 10^{2}\right)$ foi superior àquele com o esteviosídeo, porém a diferença não foi estatisticamente significante. O nível de estreptococos mutans por miligrama de placa, na presença de esteviosídeo $\left(3,46 \times 10^{2} \pm 2,86 \times 10^{2}\right)$ foi inferior ao encontrado com os adoçantes STEVITA $\circledast\left(1,75 \times 10^{4} \pm 3,31 \times 10^{4}\right)$, sacarose $\left(1,9 \times 10^{5} \pm\right.$ $\left.4,89 \times 10^{5}\right)$ e lactose $\left(1,77 \times 10^{4} \pm 2,53 \times 10^{4}\right)$. Não se registrou diferença estatisticamente significante entre os adoçantes STEVITA ${ }^{\circ}$, lactose e sacarose. Os autores concluíram, pelos resultados, que o esteviosídeo foi o adoçante que causou os menores níveis de crescimento de lactobacilos e estreptococos do grupo mutans. O produto comercial STEVITA ${ }^{\circledR}$ apresentou comportamento semelhante ao da lactose quanto ao crescimento das bactérias cariogênicas.

CORRÊA; ROSSONI; MALTZ ${ }^{20}$ (1995) estudaram o aspecto clínico do esmalte após exposição a um adoçante comercial à base de esteviosídeo e a uma solução de esteviosídeo 0,2\%. Sete pacientes usaram aparelhos de acrílico palatinos removíveis com quatro blocos de esmalte dentário e empregaram cada um, num período de 28 dias. As 
soluções teste foram: sacarose $17 \%$, STEVITA ${ }^{\circledR} 2 \%$ (esteviosídeo 0,2\% e lactose $1,8 \%$ ), lactose $1,8 \%$ e esteviosídeo 0,2\%. Após 28 dias os blocos foram removidos, limpos e estocados em água deionizada. A análise macroscópica foi realizada por dois examinadores, utilizando lupa (aumento de 15,75 vezes) em dois blocos de esmalte por experimento. Adotaram-se os seguintes critérios para exame clínico: hígido, mancha branca localizada (MBL), mancha branca generalizada (MBG) e mancha branca generalizada com cavidade (MBG $+C$ ). Os achados revelaram que a sacarose causou desmineralização em todos os blocos de esmalte e em $85,8 \%$ dos casos constatou-se a presença de cavidades (MBG + C). Não ocorreu nenhum caso de desmineralização clínica quando se utilizou o esteviosídeo. A STEVITA ${ }^{\circledR}$ ocasionou desmineralização em $21,3 \%$ dos blocos (7,1\% MBL; 7,1\% MBG e 7,1\% MBG+C), enquanto que a lactose provocou ainda mais ( $50 \%$ dos blocos, sendo $21,3 \% \mathrm{MBL} ; 14,3 \% \mathrm{MBG}$ e $14,3 \% \mathrm{MBG}+\mathrm{C})$. Os autores concluíram que o adoçante comercial à base de esteviosídeo pode causar desmineralização macroscópica no esmalte dentário sendo que a presença do esteviosídeo nesse adoçante, STEVITA $\circledast$, parece diminuir o efeito cariogênico da lactose contido na formulação.

Foi avaliado por ZANELA ${ }^{109}$ (1995), o efeito inibidor de bochechos diários com digluconato de clorexidina $0,2 \%$, fluoreto de sódio 0,05\% pH 3,4 e esteviosídeo 0,1\% sobre a placa dentária em crianças e verificados os efeitos colaterais das soluções, assim como a aceitação das mesmas, através de um questionário. Para tanto, 200 crianças entre 7 e 11 anos de idade foram divididas em 4 grupos, sendo um controle e 3 experimentais, utilizando-se para avaliação clínica o índice de placa de 
LÖE. Os grupos foram divididos da seguinte maneira: o grupo I (controle), água deionizada, o grupo II, digluconato de clorexidina 0,2\%, o grupo III, fluoreto de sódio 0,05\% pH 3,4 e o grupo IV, esteviosídeo $0,1 \%$. No início do experimento, as crianças receberam profilaxia profissional e em seguida executaram bochechos diários com $5 \mathrm{ml}$ de solução por 1 minuto, sob supervisão, durante um período de 6 semanas. Os resultados mostraram uma inibição do acúmulo de placa de 13,38\%, $52,63 \%$, 39,34\% e 30,60\%, para os grupos I, II, III e IV, respectivamente. Em relação às faces dentárias, os grupos II e III registraram maiores reduções do acúmulo de placa nas faces vestibular e lingual e o grupo IV, na face vestibular seguida da distal e mesial. A diferença entre os tratamentos foi estatisticamente significante a $5 \%$, exceto entre os grupos III e IV. Todas as soluções testadas apresentaram algum efeito colateral, sendo que a pigmentação dentária e o sabor desagradável foram mais relatados para a solução de digluconato de clorexidina. Concluiu, com a pesquisa, que todas as substâncias testadas apresentaram efeito antiplaca, sendo o digluconato de clorexidina $0,2 \%$ a de maior eficácia.

BIJELLA et al. ${ }^{11}$ (1997) avaliaram o efeito inibidor de bochechos diários com solução de esteviosídeo 0,5\% associado ao fluoreto de sódio 0,05\% pH 3,4, sobre a placa dentária, em crianças. Para tanto, 50 crianças com idades entre 7 e 11 anos foram divididas em 2 grupos, sendo 1 controle e 1 experimental, utilizando-se para avaliação clínica o índice de placa de LÖE. O exame clínico do índice de placa foi realizado no início e após 3 semanas de trabalho. No início do experimento as crianças receberam profilaxia profissional e em seguida 
executaram o primeiro bochecho. $O$ esquema aplicado foi de $5 \mathrm{ml}$ de solução, por 1 minuto, 1 vez ao dia, sob supervisão durante a semana, sendo que aos finais de semana e feriados, as crianças realizaram os bochechos em casa, com o devido suprimento e a orientação sobre os procedimentos. Os resultados mostraram uma inibição no acúmulo de placa de $2,48 \%$ e $23,82 \%$, para os grupos placebo e experimental, respectivamente. A diferença entre os tratamentos foi estatisticamente significante a 5\%. Em uma análise subjetiva, algumas crianças relataram queixa com relação ao sabor amargo da solução, apesar de não o considerarem ruim. Os autores concluíram que a solução de esteviosídeo $0,5 \%$ associado ao fluoreto de sódio 0,05\% pH 3,4 apresentou efeito antiplaca, necessitando mais pesquisas com a solução, a fim de aprimorar sua aplicabilidade clínica. 


\section{3 - PROPOSIÇÃO}




\section{- PROPOSIÇÃO}

Este projeto propôs-se a avaliar em crianças de 7 a 11 anos de idade o efeito de bochechos diários com água deionizada mentolada; gluconato de clorexidina $0,12 \%$ associado ao fluoreto de sódio 0,05\% (Duplak); digluconato de clorexidina 0,2\% (diluído do PlakOut $10 \%$ ) e esteviosídeo $0,5 \%$ associado ao fluoreto de sódio $0,05 \% \mathrm{pH}$ 3,4 sobre:

3.1 - A capacidade de inibição do acúmulo de placa dentária, utilizando-se para avaliação o índice de placa de LÖE ${ }^{62}$;

3.2 - A aceitação das soluções por essas crianças, através de um questionário;

3.3 - A presença de efeitos colaterais, verificados através de sinais clínicos e sintomas relatados pelo paciente;

3.4 - A ação antimicrobiana das soluções, utilizando-se para a avaliação a contagem de estreptococos mutans na saliva. 
4 - MATERIAL E MÉTODOS 


\section{4- MATERIAL E MÉTODOS}

Foram selecionadas 200 crianças, de ambos os sexos, com idades entre 7 e 11 anos. A amostra foi escolhida na Escola Rogacionista "Padre Paulo Petruzellis" e na Escola Municipal Santa Maria de Bauru-SP.

Previamente à seleção, solicitou-se uma autorização das Diretoras das Instituições e posteriormente foi enviado um comunicado aos pais das crianças, pedindo autorização para a participação no estudo. Realizou-se uma reunião de esclarecimento do mesmo, enfatizando a importância da colaboração e o cronograma das atividades.

$\mathrm{Na}$ avaliação inicial das crianças foram excluídas as que apresentavam aparelho ortodôntico e condições bucais precárias, como presença de raízes residuais e múltiplas lesões de cárie, com ou sem comprometimento pulpar. Em etapa posterior, os participantes se submeteram ao exame bucal quando se realizou o índice de placa inicial (I.P.I.), utilizando-se o índice proposto por LÖE ${ }^{62}$. Os achados do exame bucal e os escores foram anotados por uma auxiliar, em fichas especialmente estruturadas para a pesquisa (figura 1) e o examinador foi sempre o mesmo para todas as crianças.

$\mathrm{Na}$ mesma semana, procedeu-se a divisão dos participantes em 4 grupos, de forma que ficassem equilibrados com relação ao seu I.P.I. :

Grupo I: bochechos diários com água deionizada mentolada (controle); 
Grupo II: bochechos diários com gluconato de clorexidina 0,12\%, associada ao fluoreto de sódio 0,05\% (DUPLAK - Produtos Dentários LTDA)

Grupo III: bochechos diários com digluconato de clorexidina 0,2\% (diluída do Plak-Out 10\%);

Grupo IV: bochechos diários com esteviosídeo 0,5\% associado ao fluoreto de sódio 0,05\% pH 3,4 (Steviafarma Industrial $S / A)$.

Não se efetuou orientação com relação à técnica de higiene bucal e modificação nos hábitos dietéticos. As crianças foram conscientizadas a comparecerem diariamente para a realização dos bochechos, salientando-se a importância da prevenção da cárie dentária. Os procedimentos referentes à prevenção (orientação de higiene bucal e/ou bochechos fluoretados), realizado na Escola Municipal Santa Maria, foram suspensos 3 meses antes do início da pesquisa, bem como foram selecionadas as crianças que não tinham recebido antibióticos nesse mesmo período.

Previamente ao primeiro bochecho com as soluções, as crianças foram submetidas à profilaxia profissional, utilizando-se escovas tipo pincel, taças de borracha, pedra pomes, fio dental, sonda exploradora, espelho bucal e cotonetes. A placa foi corada por uma solução evidenciadora à base de fucsina $0,5 \%$. Imediatamente após a profilaxia profissional as crianças iniciaram o primeiro bochecho com a solução específica do seu grupo. 
As soluções eram separadas em frascos, apenas com a identificação do grupo a que pertencia (grupo I, II, III e IV) e $5 \mathrm{ml}$ das mesmas aspiradas com uma seringa descartável e distribuídas em copos de café descartáveis, o qual a criança levava à boca para realização do bochecho. Cada solução apresentava o seu material individualizado.

Repetiu-se o esquema de bochechos diários, com $5 \mathrm{ml}$ 10,105,109 de solução por 1 minuto durante 4 semanas, no início do período escolar. Os bochechos eram supervisionados diariamente pelo mesmo profissional e dava-se orientação às crianças para que ficassem 30 minutos sem nada ingerir. Aos sábados, domingos e feriados, as crianças levavam para suas casas, pequenos recipientes com a solução específica do seu grupo e com dosagem correta de $5 \mathrm{ml}$, havendo um recipiente para cada dia. Foram orientadas previamente, durante a semana, a fim de realizarem corretamente os bochechos em suas casas. Os pais colaboraram, pois também foram instruídos. Os participantes traziam de volta os recipientes para levarem devidamente preenchidos a cada final de semana.

No dia seguinte ao último bochecho, foi feito o índice de placa final (I.P.F.), pelo mesmo e único examinador que realizou o I.P.I., anotando-se na mesma ficha. Examinou-se toda cavidade bucal a fim de se detectar a presença de manchas em dentes, mucosa ou língua, bem como qualquer outro efeito colateral que porventura existisse, sendo anotados na ficha.

$\mathrm{Na}$ última semana da fase experimental, as crianças receberam um questionário que era respondido com a orientação do profissional que realizava o supervisionamento e o índice de placa. As 
perguntas foram direcionadas para verificação dos efeitos colaterais e a aceitação das soluções pelas crianças, obtendo-se informações relacionadas à alteração do paladar, bem como sabor dos alimentos, presença de manchas e sabor da solução bochechada.

A análise microbiológica constou da contagem de estreptococos mutans, na saliva estimulada, através do teste CARITEST SM (HERPO, Produtos Dentários LTDA), cuja apresentação e conteúdo estão relacionados abaixo:

- lâminas de cultura com ambos lados estéreis contendo peptona de caseína, dextrose, sacarose, azul de tripan, cristal violeta, telurito de potássio, sulfato de amônio e ágar;

- tubos estéreis, contendo o diluente tamponado, sendo este cloreto de sódio, fosfato de potássio dibásico e fosfato de potássio monobásico;

- comprimidos de bacitracina U.S.P. e aglutinante inerte;

- comprimidos geradores de $\mathrm{CO}^{2}$;

- tabletes de goma de mascar purificadas.

Para participar dessa avaliação foram selecionadas, ao acaso, 20 crianças de cada grupo, observando um período mínimo de 1 hora, sem ingestão de alimentos, para a coleta de saliva.

Um total de 3 coletas de saliva foi executado: no início (antes da profilaxia profissional), 24 horas após o primeiro bochecho e 1 semana após o último bochecho. $O$ esquema para obtenção da saliva foi feito seguindo as orientações dadas no teste. A criança mastigava o tablete de goma de mascar natural, procurando envolver todos os 
dentes, engolindo normalmente a saliva produzida nos primeiros 20 segundos. A seguir, a saliva acumulada era vertida em um funil de vidro acoplado a um tubo de centrífuga, ambos esterelizados, até se obter um volume final de $3 \mathrm{ml}$. Orientavam-se as crianças para que não conversassem durante a coleta, pois esta era feita com 5 crianças ao mesmo tempo. Na seqüência, o funil era removido, o tubo de centrífuga selado com uma rolha de borracha, identificado e levado a uma caixa de isopor contendo gelo picado que era levada ao laboratório para o processamento conforme as orientações do fabricante:

1 - A tampa do tubo contendo o diluente era removida e um sachê que continha o comprimido de bacitracina era adicionado. Recolocava-se a tampa do tubo e aguardava-se a bacitracina se dissolver por completo. Esta operação poderia ser feita até 30 minutos antes da realização do teste;

2 - A saliva coletada era homogeneizada por 1 minuto em agitador (Mixtron), numa velocidade 4;

3 - A seguir, a saliva era aspirada $(1,5 \mathrm{ml})$ com pipeta graduada estéril de $2 \mathrm{ml}$ e vertida dentro do tubo que continha o diluente com a bacitracina. O tubo era fechado e a solução homogeneizada em um agitador (Mixtron), por 1 minuto e meio na velocidade 3;

4 - Cuidadosamente, a lâmina com o meio de cultura era mergulhada no tubo contendo a mistura diluente/saliva que era então fechado, mantendo o meio de cultura imerso nesta mistura por 30 segundos;

5 - O conteúdo do sachê com a mistura geradora de $\mathrm{CO}_{2}$ era colocado no fundo do tubo vazio, que originariamente continha a 
lâmina de cultura. Logo após, duas gotas de água destilada eram adicionadas ao pó com um conta-gotas;

6 - Imediatamente era removida a lâmina do tubo diluente/saliva eliminando-se o excesso de líquido da mesma e feita sua transferência para o tubo contendo o sachê de $\mathrm{CO}_{2}$, 0 qual era assim fechado corretamente;

7 - Esse tubo era incubado em estufa a $37^{\circ} \mathrm{C}$, durante 48 horas, em posição vertical e depois deixado 24 horas em temperatura ambiente para tornar mais fácil a visualização das colônias;

8 - Para a leitura, a superfície do meio de cultura foi examinada nos dois lados a olho nu e no microscópio estereoscópico para conferir a presença de colônias de estreptococos mutans (figura 3). A densidade de crescimento das colônias na superfície do meio de cultura era comparada, a olho nu, com as densidades impressas na figura 2, que vem na embalagem do CARITEST SM. O número impresso acima de cada densidade, no quadro, reflete o número de Unidades Formadoras de Colônias (UFC) de estreptococos mutans presente na boca do paciente, por unidade ( $\mathrm{ml}$ ) de saliva (figuras 2 e 3 ).

Para análise dos resultados, utilizaram-se valores médios e percentuais. Executou-se análise de variância a um critério de KrukallWallis e o teste de Dunn para comparações individuais entre os grupos e o teste de Friedman para comparações individuais dentro dos grupos. 0 nível de significância foi de $5 \%$. 
FIGURA 1 - Ficha utilizada para anotaçăo dos escores de placa e dos L.P.L, E L.P.F.

FACULDADE DE ODONTOLOCGIA DE BALFU-INDICE DE PLAOA OELOE
NONE
EGCOLA
SExo
IOADE
ENDERECO
TURNO
SALA.
TELEFONE

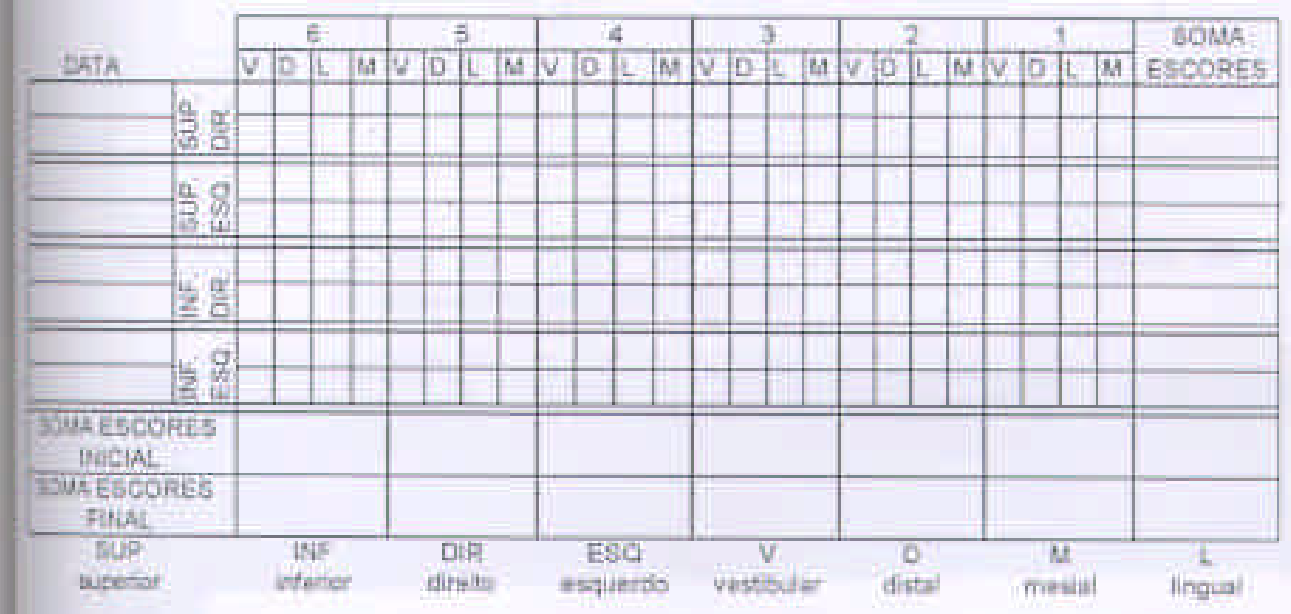

\begin{tabular}{|c|c|c|}
\hline & INACIAI & FINA \\
\hline Filifscoves & & \\
\hline 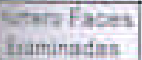 & & \\
\hline Aordis Placa & & \\
\hline & & \\
\hline
\end{tabular}

EXWME CUINICO - PRESENQQA DE MANICHAS

\begin{tabular}{|c|c|c|}
\cline { 2 - 3 } \multicolumn{1}{c|}{} & HECW & FINAL \\
\hline DENTE & & \\
\hline LABIO & & \\
\hline POCHECHA & & \\
\hline UINGUA & & \\
\hline
\end{tabular}




\section{QUADRO DE AVALIAÇĀO DOS RESULTADOS}
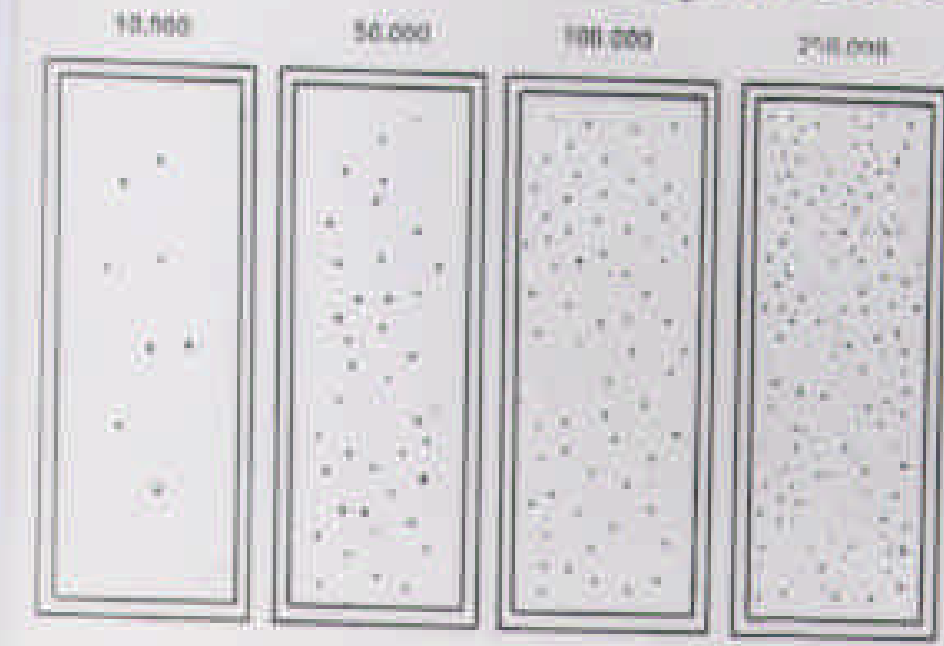

sivi ono

I hos son
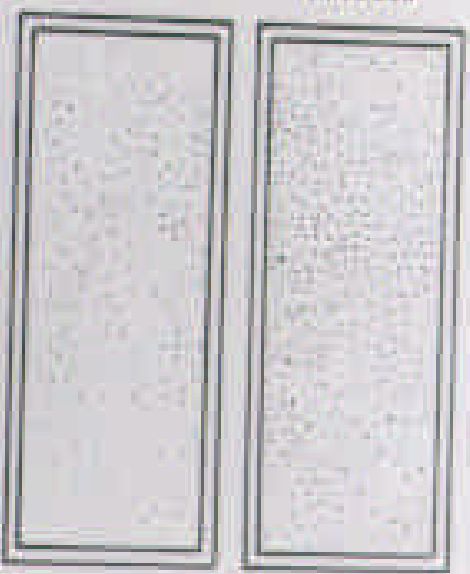

FIGURA 2 - Quadro da Tabela de densidade para comparações da contagem microbiológica do CARITEST SM

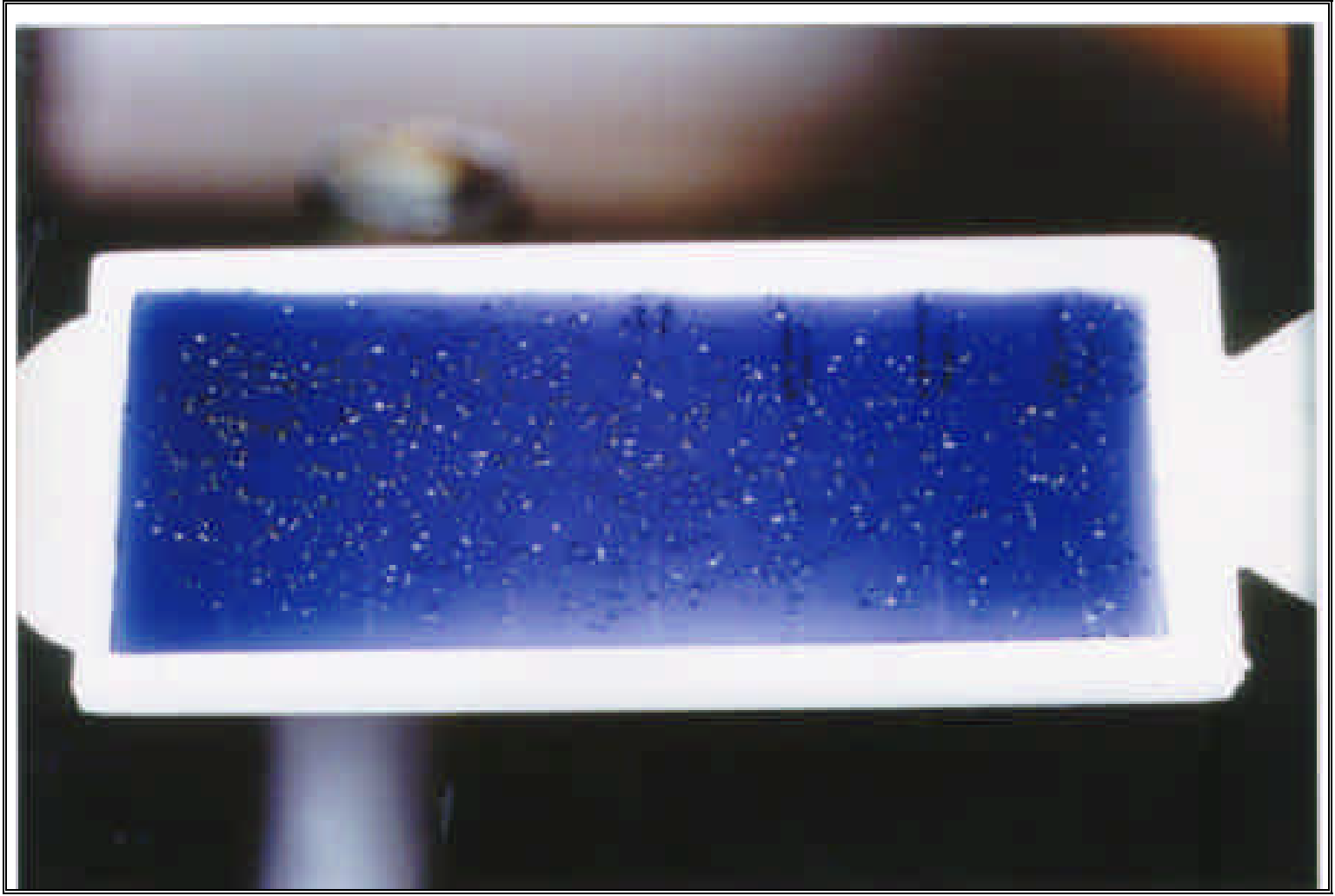

FIGURA 3 - Exemplo da densidade verificada da lâmina do CARITEST SM escore 3 (500.000) 


\section{5 - RESULTADOS}




\section{5- RESULTADOS}

Os resultados desta pesquisa serão divididos em 2 partes. A análise clínica que consiste na avaliação da inibição de placa e dos efeitos colaterais das substâncias e a segunda, sobre a análise microbiológica das mesmas devido as duas análises feitas apresentarem características especiais sendo totalmente separadas.

\section{1 - Análise Clínica}

A análise clínica foi feita através do índice de placa de LÖE ${ }^{62}$, exame clínico e questionário para a verificação dos efeitos colaterais e os resultados estão apresentados em 14 Tabelas, 6 figuras.

A Tabela 1 representa a amostra inicial selecionada, constando de 200 crianças, das quais 177 concluíram efetivamente 0 experimento ao final de 4 semanas.

Com relação à distribuição inicial das crianças nos grupos de estudo, pode-se notar uma certa homogeneidade em relação ao índice de placa inicial (I.P.I.), destacada na Tabela 3.

Os resultados registrados na Tabela 2 revelam as diferenças das reduções obtidas, relacionando-as com os escores 0 , 1,2 e 3 . Evidencia-se que para todos os grupos houve um aumento em termos percentuais de escores 0 (face livre de placa), sendo que nos grupos II e III, este fato foi mais destacado. Com relação ao escore 1, relatou-se um aumento percentual para os grupos que 
bochecharam com solução ativa. Nos grupos II e III, tem-se uma visível queda percentual de registro do escore 2 (placa visível), revelando a eficácia dessas soluções no controle do acúmulo de placa dentária. Denota-se também que, houve muitos poucos casos de registro do escore 3 (abundante acúmulo de placa), para o grupo III e IV ao final das 4 semanas de tratamento.

Na Tabela 3 e figura 4, evidencia-se a média do índice de placa inicial (I.P.I.) e final (I.P.F.) para os grupos I, II, III e IV, sendo que o I.P.F. foi de 1,$451 ; 1,122 ; 0,866$ e 1,431, respectivamente. Decorridas as 4 semanas de realização dos bochechos diários, com uma das soluções, associadas à higiene bucal habitual, presenciou-se redução do índice de placa em todas as crianças, independente do tipo de solução. A redução percentual para os grupos com solução ativa II, III e IV, foi de $26,75 \% ; 41,20 \%$ e 5,91\%, respectivamente (figura 5).

Fundamentando-se nos valores referentes às diferenças entre os I.P.I. e I.P.F. dos 4 grupos, foram executados os testes de Kruskal-Wallis e de Dunn (Tabelas 4 e 5). Os resultados foram estatisticamente significantes para a boca toda, sendo o equivalente de $\mathrm{Hc}=75,537720$, que foi maior que $\chi^{2}=7,815$ e $\mathrm{p}<0,00001$. Os dados obtidos no teste de Dunn sobre as diferenças dos escores médios da placa inicial e final, para a boca toda, estão registrados na Tabela 5. As comparações entre essas diferenças foram estatisticamente significantes entre os grupos II e III com o grupo I e o grupo IV. Para as crianças dos grupos I e IV, que apresentaram menor redução percentual (Tabela 3), não houve diferença estatisticamente significante, pois o valor crítico foi 
de 29,499 e a diferença dos postos 3,01. Também entre os grupos II e III não houve diferença estatisticamente significante.

Procurando-se registrar o comportamento das soluções em relação às faces dentárias, elaboraram-se as Tabelas 6, 7 e 8 que expressam os valores numéricos das médias do índice de placa inicial e final para as faces vestibular, lingual e proximais dos grupos I, II, III e IV, respectivamente. Globalmente, em todas as faces, houve uma redução semelhante na média do índice de placa para os grupos II e III isoladamente, mostrando que os bochechos foram eficazes na sua ação antiplaca para esses grupos e no grupo IV, observa-se que a redução foi melhor para a superfície lingual.

As figuras 6, 7 e 8 ilustram a média do índice de placa inicial e final, para as faces vestibular, lingual e proximais, salientando 0 efeito antiplaca das soluções dos grupos II e III considerando, ainda, o fato de que a mais eficaz, em todas as faces dentárias, foi a solução de digluconato de clorexidina $0,2 \%$ (grupo III), seguido pelo grupo II.

Nas Tabelas de 9 a 13 destaca-se a análise de variância e as comparações individuais entre as faces dentárias dos tratamentos, respectivamente para os grupos I, II, III e IV, de acordo com o teste de Friedman. Estas Tabelas demonstram que houve diferença significante entre as faces vestibular/distal e lingual/distal para o grupo I. Com relação ao grupo II, não houve essa significância entre as faces dentárias. Já para o grupo III observa-se diferença estatisticamente significante entre as faces vestibular/distal vestibular/lingual e a lingual/mesial. No grupo IV, o resultado revelou essa diferença estatisticamente significante entre as faces distal/lingual. Dadas essas 
informações, pode-se dizer, retrocedendo para as Tabelas 6, 7 e 8, que as faces dentárias tiveram semelhante interação com os bochechos para o grupo II, sendo que para o grupo IV a face lingual apresentou melhor resultado que as faces proximais. $\mathrm{E}$ como pode ser visto nas Tabelas 6, 7 e 8, este fato pode ser devido a uma melhor redução do índice de placa na superfície lingual.

Outro alvo da pesquisa foi avaliar a aceitação das soluções para bochechos pelas crianças, relacionada ao sabor, alteração do paladar e alteração no sabor dos alimentos, bem como a evidenciação dos efeitos colaterais ligados às pigmentações dentárias e ulcerações em mucosas. De acordo com a Tabela 14, essas pigmentações foram observadas no grupo II que utilizou bochechos com solução de gluconato de clorexidina $0,12 \%$ associado ao fluoreto de sódio 0,05\% e no grupo III que usou a solução de digluconato de clorexidina $0,2 \%$ para bochecho. Quanto às respostas as demais questões, de um modo geral, o grupo III apresentou resultados menos favoráveis, o que pode, também, ser verificado na Tabela 14.

$\mathrm{Na}$ interrogação às crianças, quanto as suas próprias observações da presença de manchas em suas cavidades bucais, apenas 5 crianças do grupo III evidenciaram as pigmentações em seus dentes e estas se localizavam nos dentes anteriores.

Pode-se considerar, ainda, que das 47 crianças, examinadas do grupo II, 7 tiveram coloração marrom-castanha nos dentes e das 43 do grupo III, esse valor foi de 12, sendo que estas foram suaves. As pigmentações em língua e mucosas não foram evidenciadas. 
Segundo a análise das respostas obtidas das crianças, em relação à opinião do sabor das soluções, observa-se na figura 9, que em relação ao sabor agradável, o grupo I relatou $56,41 \%$ dessa referência; o grupo II registrou $65,96 \%$, o grupo III foi o menos aceito, onde obtevese $20,93 \%$ e o grupo IV, $38,89 \%$. Em relação ao sabor amargo, as crianças do grupo III, o referenciaram em 53,49\%, vindo a seguir o grupo IV com $41,67 \%$ e o grupo II com $6,76 \%$ (Tabela 14 ). 
TABELA 1 - Número de crianças na fase inicial e final do experimento para verificação do índice de placa de $L O ̈ E^{62}$

\begin{tabular}{cccc}
\hline GRUPOS & INICIAL & FINAL & PERDA (\%) \\
\hline I & 50 & 42 & 16 \\
II & 50 & 45 & 10 \\
III & 50 & 48 & 4 \\
IV & 50 & 42 & 16 \\
\hline
\end{tabular}

TABELA 2 - Valores percentuais dos escores do índice de placa de LÖE ${ }^{62}$ dos grupos, no início e fim do experimento

\begin{tabular}{crrrrrrrrr}
\hline & \multicolumn{3}{c}{ I } & \multicolumn{2}{c}{ II } & \multicolumn{2}{c}{ III } & \multicolumn{3}{c}{ IV } \\
ESCORE & INICIAL & FINAL & INICIAL & FINAL & INICIAL & FINAL & INICIAL & FINAL \\
\hline 0 & 5,89 & 10,44 & 5,58 & 21,98 & 6,05 & 35,92 & 6,39 & 9,33 \\
1 & 38,75 & 34,57 & 37,01 & 45,57 & 39,35 & 41,92 & 35,96 & 38,63 \\
2 & 53,23 & 54,28 & 52,72 & 31,24 & 52,72 & 21,78 & 56,89 & 51,96 \\
3 & 2,13 & 0,71 & 1,82 & 1,21 & 1,88 & 0,38 & 0,76 & 0,08 \\
& 100 & 100 & 100 & 100 & 100 & 100 & 100 & 100 \\
\hline
\end{tabular}

TABELA 3 - Médias, desvios padrão e redução percentual entre o índice de placa $\left(\mathrm{LÖE}^{62}\right.$ ) inicial e final, nos grupos de estudo

\begin{tabular}{crrrrr}
\hline & \multicolumn{2}{c}{ I.P.I. } & \multicolumn{2}{c}{ I.P.F. } & \multicolumn{2}{c}{ DIFERENÇA } & REDUÇÃO \\
GRUPO & \multicolumn{1}{c}{$\begin{array}{r}\text { D.P. } \\
\text { X }\end{array}$} & D.P. & \multicolumn{1}{c}{$\bar{X}$} & D.P. & $(\%)$ \\
\hline I & $1,513 \pm 0,292$ & $1,451 \pm 0,294$ & $0,062 \pm 0,217$ & 4,10 \\
II & $1,532 \pm 0,311$ & $1,122 \pm 0,325$ & $0,410 \pm 0,285$ & 26,75 \\
III & $1,502 \pm 0,309$ & $0,866 \pm 0,383$ & $0,637 \pm 0,404$ & 41,20 \\
IV & $1,522 \pm 0,264$ & $1,431 \pm 0,294$ & $0,091 \pm 0,164$ & 5,91 \\
\hline
\end{tabular}




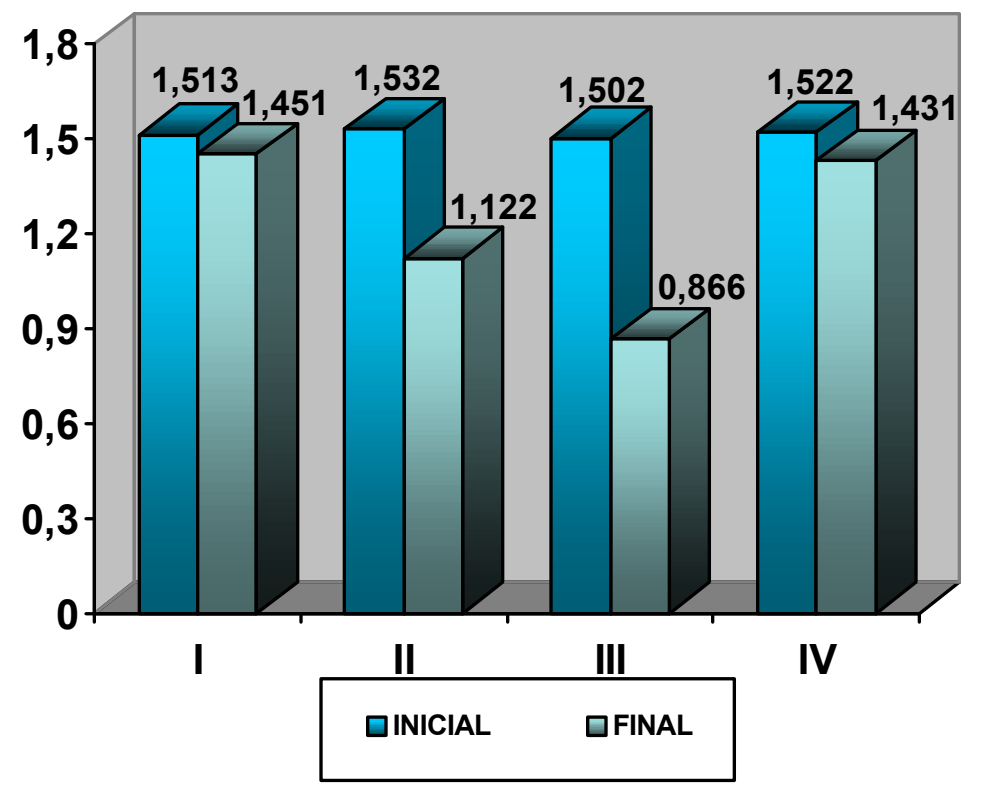

Figura 4 - Médias da boca toda do índice de placa (Löe ${ }^{62}$ ) inicial e final nos grupos de estudo

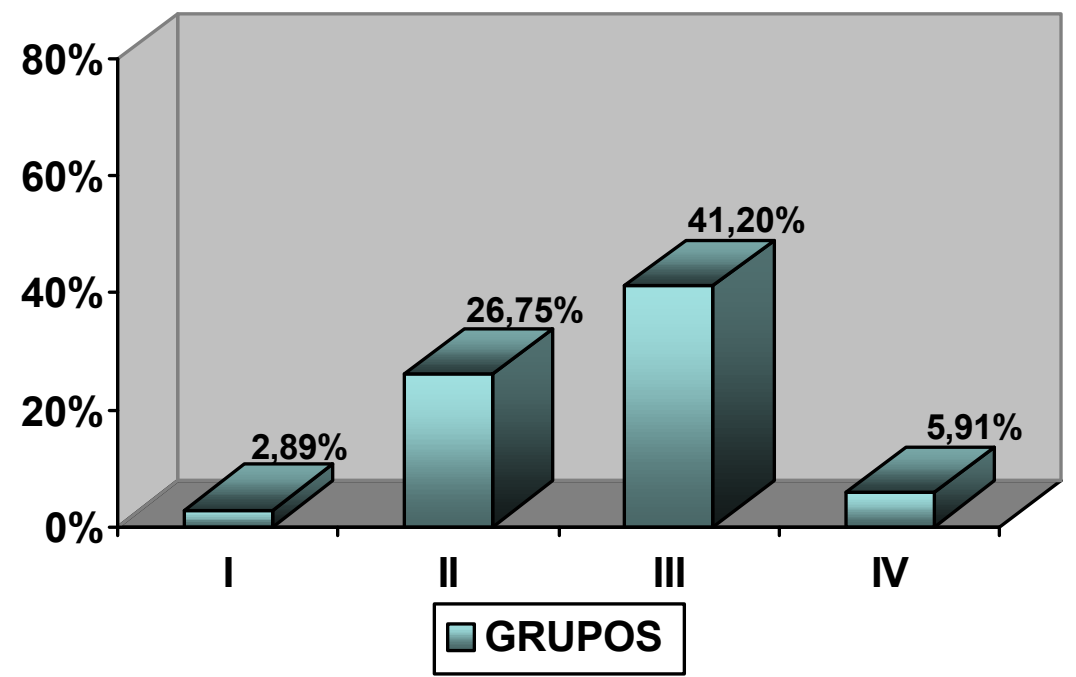

Figura 5 - Redução percentual do índice de placa $\left(\right.$ Löe $\left.^{57}\right)$ nos grupos de estudo 
TABELA 4 - Resultados do teste de Kruskal-Wallis para efeitos de tratamento sobre a diferença dos escores médios de placa inicial e final da boca toda

\begin{tabular}{|c|c|c|c|c|}
\hline GRUPOS & AMOSTRA & ESCORE & SOMA DOS POSTOS & POSTO MÉDIO \\
\hline I & 42 & 0,0624 & 5225 & 124,39 \\
\hline II & 45 & 0,4098 & 3208 & 71,29 \\
\hline III & 48 & 0,6367 & 223 & 46,30 \\
\hline IV & 42 & 0,0910 & 5098 & 121,38 \\
\hline \multicolumn{5}{|c|}{$\begin{array}{l}\mathrm{HC}=75,537720-\text { Significante } \\
2^{2}{ }_{4}(5 \%)=7,815 \quad \mathrm{p}<0,00001\end{array}$} \\
\hline
\end{tabular}

TABELA 5 - Resultados do teste de Dunn para efeitos de comparações individuais entre os tratamentos, sobre a diferença dos escores médios de placa inicial e final entre os postos médios dos grupos.

\begin{tabular}{ccccc}
\hline \multicolumn{2}{c}{ GRUPOS } & \multicolumn{2}{c}{ DIFERENÇA } & VALOR CRÍTICO \\
\hline I & $x$ & II & $53,10 * *$ & 29,004 \\
I & $x$ & III & $78,09 * *$ & 28,563 \\
I & $x$ & IV & 3,01 & 29,499 \\
II & $x$ & III & 24,99 & 28,050 \\
II & $x$ & IV & $50,09 *$ & 29,004 \\
III & $x$ & IV & $75,08 *$ & 28,563 \\
\hline \multicolumn{5}{c}{} \\
\end{tabular}


TABELA 6 - Médias, desvios padrão e redução percentual entre o índice de placa ( $\left(\mathrm{OOE}^{62}\right.$ ) inicial e final, nos grupos de estudo, da face vestibular.

\begin{tabular}{|c|c|c|c|c|}
\hline \multirow[t]{2}{*}{ GRUPO } & I.P.I. & I.P.F. & DIFERENÇA & \multirow{2}{*}{$\begin{array}{c}\text { REDUÇÃO } \\
(\%)\end{array}$} \\
\hline & D.P. & D.P. & D.P. & \\
\hline I & $1,506 \pm 0,367$ & $1,401 \pm 0,367$ & $0,105 \pm 0,283$ & 6,97 \\
\hline II & $1,545 \pm 0,407$ & $1,102 \pm 0,494$ & $0,443 \pm 0,375$ & 28,67 \\
\hline III & $1,493 \pm 0,411$ & $0,776 \pm 0,499$ & $0,717 \pm 0,501$ & 48,01 \\
\hline IV & $1,523 \pm 0,351$ & $1,436 \pm 0,402$ & $0,087 \pm 0,248$ & 5,71 \\
\hline
\end{tabular}

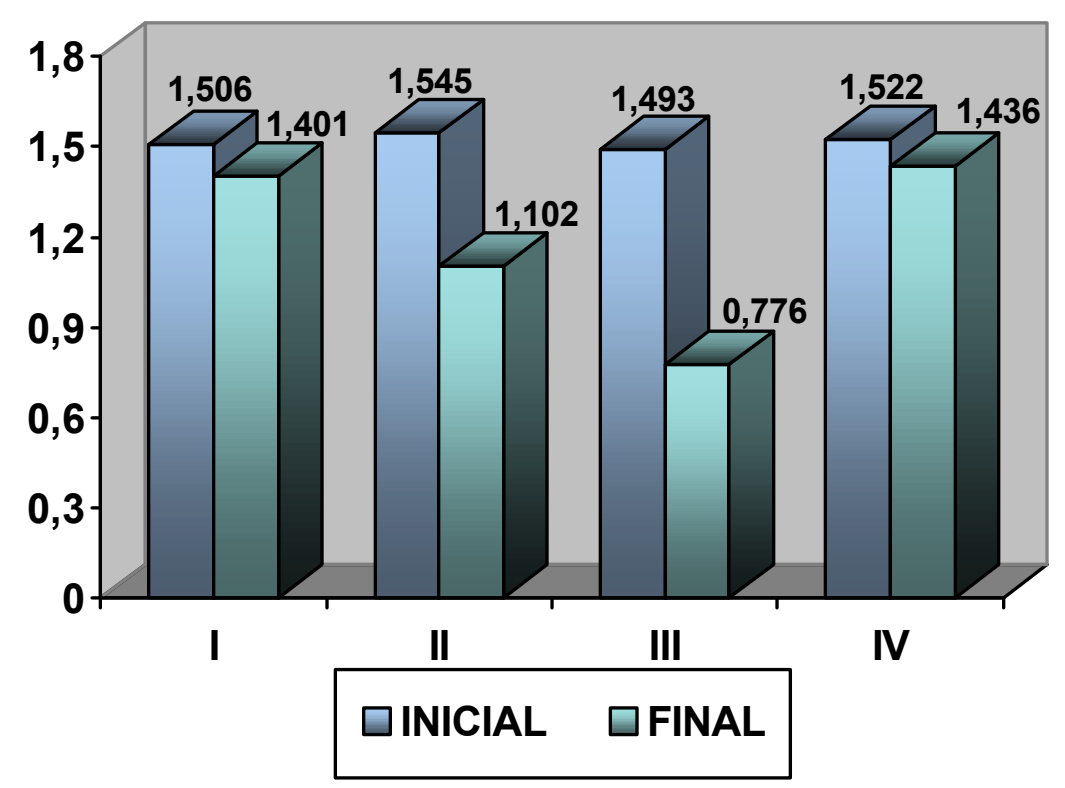

Figura 6 - Médias das faces vestibular do índice de placa $\left(\right.$ Löe $\left.^{62}\right)$ inicial e final nos grupos de estudo 
TABELA 7 - Médias, desvios padrão e redução percentual entre o índice de placa $\left(L O ̈ E^{62}\right.$ ) inicial e final, nos grupos de estudo, da face lingual

\begin{tabular}{|c|c|c|c|c|}
\hline \multirow[t]{2}{*}{ GRUPO } & I.P.I. & I.P.F. & DIFERENÇA & \multirow{2}{*}{$\begin{array}{c}\text { REDUÇÃO } \\
(\%)\end{array}$} \\
\hline & D.P. & D.P. & D.P. & \\
\hline I & $1,434 \pm 0,244$ & $1,316 \pm 0,298$ & $0,118 \pm 0,241$ & 8,23 \\
\hline II & $1,382 \pm 0,275$ & $1,027 \pm 0,347$ & $0,356 \pm 0,359$ & 25,76 \\
\hline III & $1,371 \pm 0,321$ & $0,806 \pm 0,371$ & $0,565 \pm 0,434$ & 41,21 \\
\hline IV & $1,414 \pm 0,282$ & $1,265 \pm 0,271$ & $0,149 \pm 0,210$ & 10,54 \\
\hline
\end{tabular}

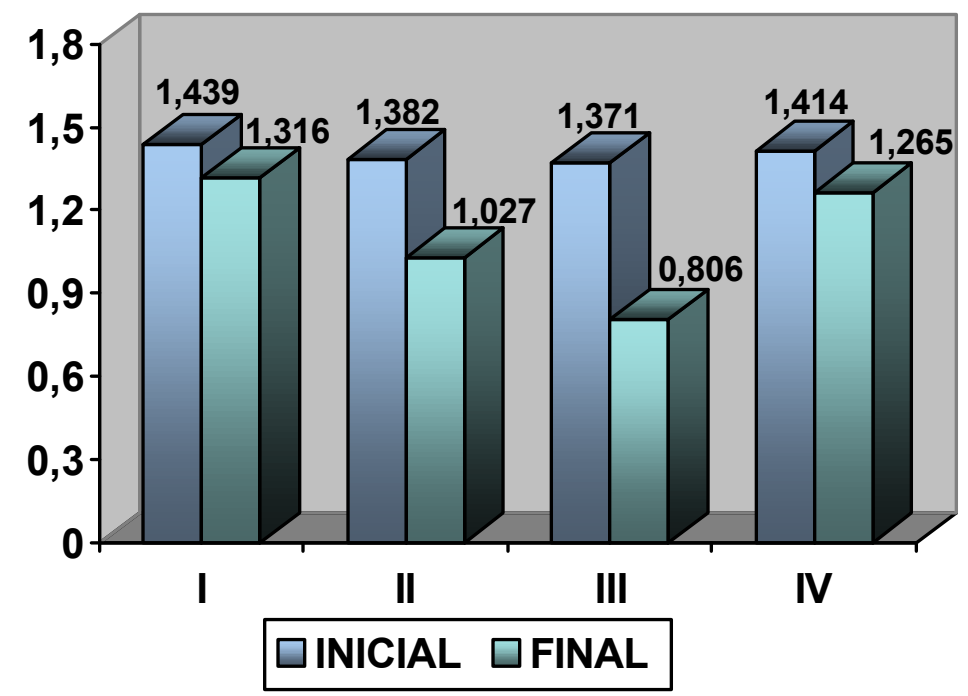

Figura 7 - Médias da face lingual do índice de placa $\left(\right.$ Löe $\left.^{62}\right)$ inicial e final nos grupos de estudo 
TABELA 8 - Médias, desvios padrão e redução percentual entre o índice de placa ( $\left(\mathrm{COE}^{62}\right.$ ) inicial e final, nos grupos de estudo, das faces proximais

\begin{tabular}{|c|c|c|c|c|}
\hline \multirow[t]{2}{*}{ GRUPO } & I.P.I. & I.P.F. & DIFERENÇA & \multirow{2}{*}{$\begin{array}{c}\text { REDUÇÃO } \\
(\%)\end{array}$} \\
\hline & D.P. & D.P. & D.P. & \\
\hline I & $1,556 \pm 0,318$ & $1,544 \pm 0,531$ & $0,012 \pm 0,240$ & 0,78 \\
\hline II & $1,600 \pm 0,320$ & $1,181 \pm 0,580$ & $0,419 \pm 0,289$ & 26,18 \\
\hline III & $1,572 \pm 0,290$ & $0,866 \pm 0,440$ & $0,631 \pm 0,385$ & 44,95 \\
\hline IV & $1,576 \pm 0,246$ & $1,511 \pm 0,583$ & $0,066 \pm 0,170$ & 4,16 \\
\hline
\end{tabular}

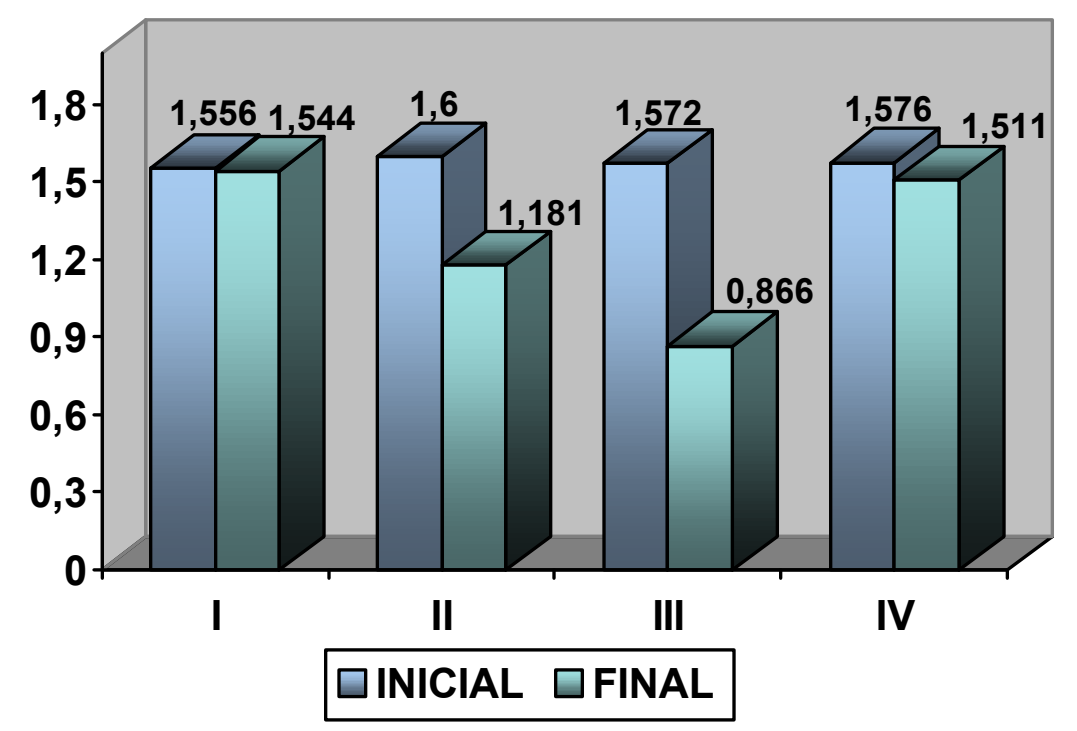

Figura 8 - Médias das faces proximais do índice de placa $\left(L_{O} E^{62}\right)$ inicial e final nos grupos de estudo 
TABELA 9 - Resultados do teste de Friedman para efeito de comparações individuais entre as faces dentárias sobre a diferença de postos do grupo I

$$
\chi^{2}(n=42, k=3)=13,00741 \quad p<0.00463
$$

FACES POSTO MÉDIO SOMA DE POSTOS MÉDIA DESVIO PADRÃO

\begin{tabular}{lrrrr} 
DIF V & 2,214286 & 93,0000 & 0,105000 & 0,283224 \\
DIF D & 3,023809 & 127,0000 & 0,008810 & 0,245994 \\
DIF L & 2,142857 & 90,0000 & 0,117857 & 0,241293 \\
DIF M & 2,619048 & 110,0000 & 0,032619 & 0,252587 \\
\hline
\end{tabular}

TABELA 10 - Resultados do teste de Friedman para efeito de comparações individuais entre as faces dentárias sobre a diferença de postos do grupo II.

$$
\chi^{2}(n=45, k=3)=3,212329 \quad p<0.36005
$$

FACES POSTO MÉDIO SOMA DE POSTOS MÉDIA DESVIO PADRÃO

\begin{tabular}{lllll}
\hline DIF V & 2,277778 & 102,5000 & 0,442889 & 0,375921 \\
DIF D & 2,466667 & 111,0000 & 0,440667 & 0,293725 \\
DIF L & 2,755556 & 124,0000 & 0,355778 & 0,359295 \\
DIF M & 2,500000 & 112,5000 & 0,398667 & 0,303612 \\
\hline
\end{tabular}


TABELA 11 - Resultados do teste de Friedman, para efeito de comparações individuais entre as faces dentárias sobre a diferença de postos do grupo III

$$
\chi^{2}(n=48, k=3)=21,77234 \quad p<0.00007
$$

FACES POSTO MÉDIO SOMA DE POSTOS MÉDIA DESVIO PADRÃO

\begin{tabular}{lrrrr}
\hline DIF V & 1,937500 & 93,0000 & 0,716875 & 0,501327 \\
DIF D & 2,781250 & 133,5000 & 0,581875 & 0,382075 \\
DIF L & 3,031250 & 145,5000 & 0,564792 & 0,434359 \\
DIF M & 2,250000 & 108,0000 & 0,681458 & 0,415754 \\
\hline
\end{tabular}

TABELA 12 - Resultados do teste de Friedman, para efeito de comparações individuais entre as faces dentárias sobre a diferença de postos do grupo IV

$$
\chi^{2}(n=42, k=3)=8,836228 \quad p<0.03156
$$

FACES POSTO MÉDIO SOMA DE POSTOS MÉDIA DESVIO PADRÃO

\begin{tabular}{ccccc}
\hline DIF V & 2,583333 & 108,5000 & 0,086905 & 0,248562 \\
DIF D & 2,809524 & 118,0000 & 0,048571 & 0,194968 \\
DIF L & 2,023809 & 85,0000 & 0,148810 & 0,210461 \\
DIF M & 2,583333 & 108,5000 & 0,082143 & 0,162339 \\
\hline
\end{tabular}


TABELA 13 - Resultados do teste de Friedman para efeito de comparações individuais entre as faces dentárias sobre a diferença de postos dos grupos I, III e IV

\begin{tabular}{|c|c|c|c|c|c|c|}
\hline \multicolumn{7}{|c|}{ DIFERENÇA } \\
\hline \multicolumn{3}{|c|}{ FACES DENTÁRIAS } & GRUPO I & \multicolumn{2}{|c|}{ GRUPO III } & \multirow{2}{*}{$\begin{array}{c}\text { GRUPO IV } \\
9,5\end{array}$} \\
\hline V & $x$ & $\mathrm{D}$ & 34 & 40,5 & $*$ & \\
\hline V & $x$ & $\mathrm{~L}$ & 3 & 52,5 & $*$ & 23,5 \\
\hline V & $x$ & $M$ & 17 & \multicolumn{2}{|c|}{15} & 0 \\
\hline D & $x$ & $\mathrm{~L}$ & $37 *$ & \multicolumn{2}{|c|}{12} & $33 *$ \\
\hline$D$ & $x$ & M & 17 & \multicolumn{2}{|c|}{25,5} & 9,5 \\
\hline \multirow[t]{2}{*}{$\mathrm{L}$} & $x$ & $M$ & 20 & 37,5 & $*$ & 23,5 \\
\hline & & & $\mathrm{VC}=30$ & \multicolumn{2}{|c|}{$V C=32,5$} & $V C=30,5$ \\
\hline
\end{tabular}


TABELA 14 - Valores referentes às respostas do questionário aplicado às crianças, de acordo com o total da amostra que executou esse procedimento

\begin{tabular}{|c|c|c|c|c|c|}
\hline \multirow[t]{2}{*}{ Questionário } & \multirow[b]{2}{*}{ Respostas } & \multicolumn{4}{|c|}{ GRUPOS } \\
\hline & & $\mathrm{I}$ & II & III & IV \\
\hline \multirow[t]{2}{*}{ Sabor } & $\begin{array}{l}\text { Amargo } \\
\text { Ardido } \\
\text { Azedo }\end{array}$ & $\begin{array}{l}4 \\
5 \\
0\end{array}$ & $\begin{array}{l}3 \\
6 \\
0\end{array}$ & $\begin{array}{c}23 \\
4 \\
3\end{array}$ & $\begin{array}{l}15 \\
- \\
2\end{array}$ \\
\hline & Total das Resp. & 9 & 9 & 30 & 17 \\
\hline \multirow[t]{2}{*}{$\begin{array}{l}\text { Opinião } \\
\text { Quanto } \\
\text { ao Sabor }\end{array}$} & $\begin{array}{c}\text { Agradável } \\
\text { Ruim } \\
\text { Mais ou menos }\end{array}$ & $\begin{array}{c}22 \\
5 \\
12\end{array}$ & $\begin{array}{c}31 \\
5 \\
11\end{array}$ & $\begin{array}{c}9 \\
14 \\
20\end{array}$ & $\begin{array}{c}14 \\
5 \\
17\end{array}$ \\
\hline & Total das Resp. & 39 & 47 & 43 & 36 \\
\hline \multirow{2}{*}{$\begin{array}{l}\text { Alteração } \\
\text { Do } \\
\text { Paladar }\end{array}$} & $\begin{array}{l}\text { Sim } \\
\text { Não }\end{array}$ & $\begin{array}{c}0 \\
39\end{array}$ & $\begin{array}{c}6 \\
41\end{array}$ & $\begin{array}{l}24 \\
19\end{array}$ & $\begin{array}{c}0 \\
36\end{array}$ \\
\hline & Total das Resp. & 39 & 47 & 43 & 36 \\
\hline \multirow{2}{*}{$\begin{array}{c}\text { Alteração } \\
\text { do Sabor } \\
\text { dos Alimentos }\end{array}$} & $\underset{\text { Não }}{\operatorname{Sim}}$ & $\begin{array}{c}0 \\
39\end{array}$ & $\begin{array}{c}5 \\
42\end{array}$ & $\begin{array}{l}17 \\
26\end{array}$ & $\begin{array}{c}0 \\
36\end{array}$ \\
\hline & Total das Resp. & 39 & 47 & 43 & 36 \\
\hline \multirow{2}{*}{$\begin{array}{c}\text { Presença } \\
\text { De } \\
\text { Pigmentação }\end{array}$} & $\begin{array}{l}\text { Sim } \\
\text { Não }\end{array}$ & $\begin{array}{c}0 \\
39\end{array}$ & $\begin{array}{c}7 \\
40\end{array}$ & $\begin{array}{l}12 \\
31\end{array}$ & $\begin{array}{c}0 \\
36\end{array}$ \\
\hline & Total das Resp. & 39 & 47 & 43 & 36 \\
\hline
\end{tabular}




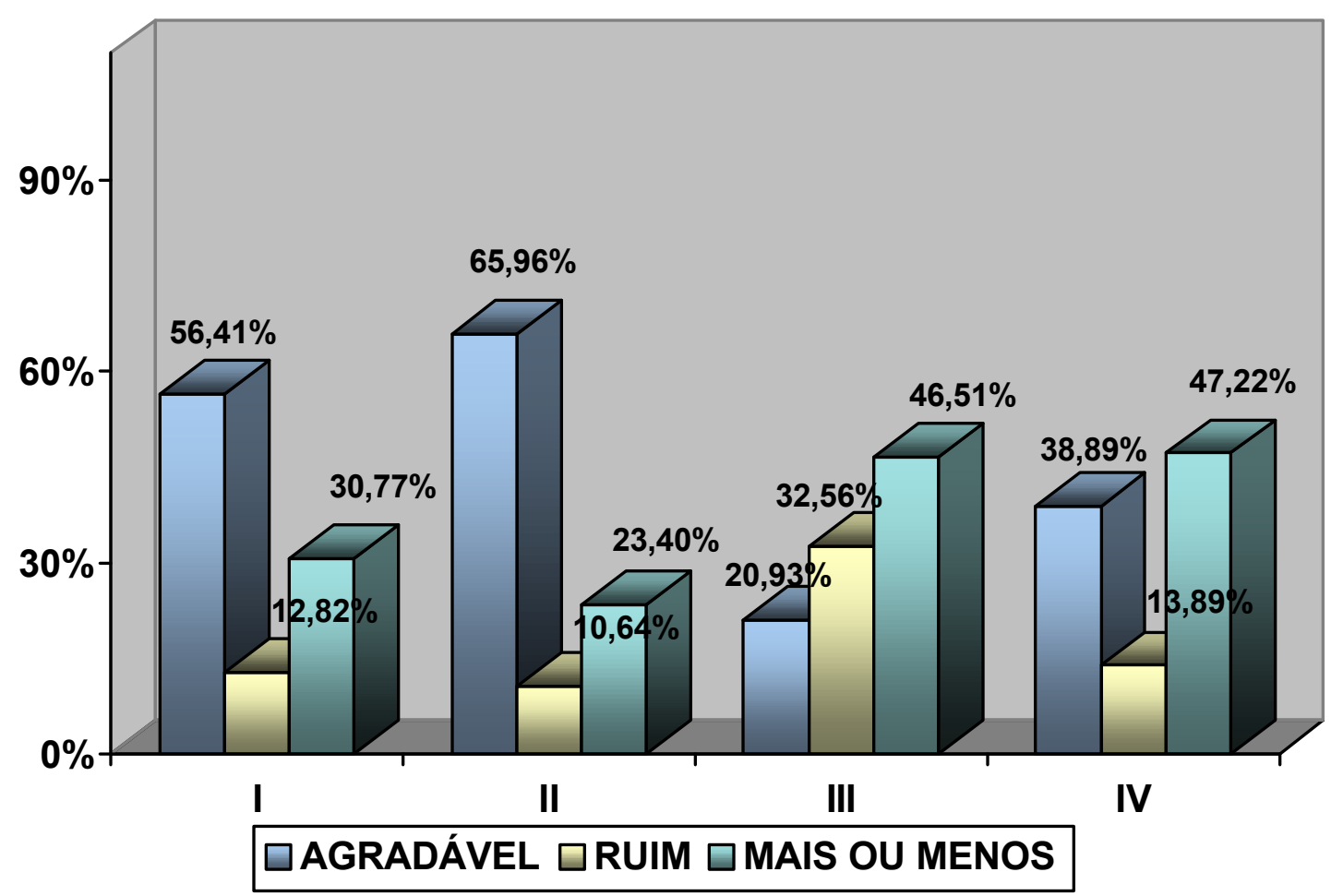

Figura 9 - Percentual do sabor registrado pelas crianças após o experimento

\section{2 - Análise Microbiológica}

Os resultados da análise microbiológica estão presentes em 6 Tabelas (Tabelas 15 a 20).

Na Tabela 15 tem-se o número de crianças no início e final do experimento, as quais executaram as 3 etapas da coleta de saliva.

$\mathrm{Na}$ figura 3 observa-se o modelo do crescimento microbiano numa lâmina de Caritest SM.

Nas Tabelas 16 a 19 são apresentados os resultados das contagens de estreptococos mutans feitas antes, 24 horas após 0 
primeiro bochecho e uma semana após o último, juntamente com os índices de placa inicial e final, das crianças selecionadas dos quatros grupos. A comparação entre as três contagens, feita através do teste de Friedman é vista na Tabela 20, não se observando diferença estatisticamente significante entre momentos em nenhum grupo. Para essa avaliação, as contagens iguais a 10.000, 50.000 e 100.000 foram agrupadas sob um único escore (1), as de 250.000 receberam o escore 2, de 500.000 , o escore 3 e de 1.000 .000 , o escore 4.

Nos grupos II e III nota-se que houve redução na contagem de estreptococos mutans nas crianças que estavam com um elevado nível de contaminação como as de número 22, 25, 28, 29, (Tabela 17) e a de número 13 (Tabela 18) verifica-se também, as crianças 3 e 6 (Tabela 18) que apresentaram um aumento nesse nível. Já em relação aos grupos I e IV, as crianças permaneceram com o nível de contaminação semelhante em todas as etapas (Tabelas 16 e 19), com exceção da criança número 44, do grupo I, que teve uma redução desses microrganismos (Tabela 16).

TABELA 15 - Número de crianças no exame microbiológico nas fases inicial e final do experimento

\begin{tabular}{cccc}
\hline GRUPOS & INICIAL & FINAL & PERDA (\%) \\
\hline I & 20 & 18 & 10 \\
II & 20 & 18 & 10 \\
III & 20 & 19 & 5 \\
IV & 20 & 20 & 0 \\
\hline
\end{tabular}


TABELA 16 - Contagens de estreptococos mutans antes, 24 horas após 0 primeiro bochecho e uma semana após o último e índices de placa inicial e final para o grupo I (placebo)

\begin{tabular}{|c|c|c|c|c|c|}
\hline CRIANÇA & ANTES & 24h APÓS & 1 SEMANA APÓS & IPI & IPF \\
\hline 41 & $250.000(2)$ & $10.000(1)$ & $500.000(3)$ & 1,706 & 1,765 \\
\hline 42 & $100.000(1)$ & $50.000(1)$ & 0 & 1,813 & 1,750 \\
\hline 43 & 0 & 0 & 0 & 1,125 & 0,854 \\
\hline 44 & $500.000(3)$ & $50.000(1)$ & $50.000(1)$ & 1,329 & 1,337 \\
\hline 45 & $250.000(2)$ & $50.000(1)$ & $100.000(1)$ & 1,813 & 2,125 \\
\hline 46 & $50.000(1)$ & $50.000(1)$ & $10.000(1)$ & 1,750 & 1,750 \\
\hline 47 & $50.000(1)$ & $10.000(1)$ & $10.000(1)$ & 1,455 & 1,455 \\
\hline \multicolumn{6}{|l|}{48} \\
\hline 49 & $10.000(1)$ & $10.000(1)$ & $10.000(1)$ & 1,207 & 1,369 \\
\hline 50 & $50.000(1)$ & $10.000(1)$ & $10.000(1)$ & 1,615 & 1,823 \\
\hline \multicolumn{6}{|l|}{51} \\
\hline 52 & $10.000(1)$ & $10.000(1)$ & $10.000(1)$ & 1,012 & 0,954 \\
\hline 53 & $50.000(1)$ & $250.000(2)$ & $10.000(1)$ & 1,413 & 1,425 \\
\hline 54 & $10.000(1)$ & $10.000(1)$ & $50.000(1)$ & 1,329 & 1,500 \\
\hline 55 & 0 & $10.000(1)$ & $50.000(1)$ & 2,043 & 1,727 \\
\hline 56 & $500.000(3)$ & $10.000(1)$ & $1.000 .000(4)$ & 1,520 & 1,657 \\
\hline 57 & $10.000(1)$ & $10.000(1)$ & $10.000(1)$ & 1,762 & 1,583 \\
\hline 58 & $10.000(1)$ & $10.000(1)$ & $250.000(2)$ & 1,326 & 1,562 \\
\hline 59 & 0 & $10.000(1)$ & $100.000(1)$ & 1,237 & 1,087 \\
\hline 60 & $10.000(1)$ & $10.000(1)$ & $10.000(1)$ & 1,443 & 1,341 \\
\hline
\end{tabular}


TABELA 17 - Contagens de estreptococos mutans antes, 24 horas após 0 primeiro bochecho e uma semana após o último e índices de placa inicial e final para o grupo II (DUPLAK)

\begin{tabular}{cccccc}
\hline CRIANÇA & ANTES & 24h APÓS & 1 SEMANA APÓS & IPI & IPF \\
\hline 21 & $10.000(1)$ & $10.000(1)$ & 0 & 1,563 & 1,250 \\
22 & $500.000(3)$ & $100.000(1)$ & $50.000(1)$ & 1,219 & 1,104 \\
23 & $10.000(1)$ & $50.000(1)$ & $10.000(1)$ & 0,708 & 0,787 \\
24 & 0 & $10.000(1)$ & 0 & 1,563 & 1,312 \\
25 & $500.000(3)$ & $10.000(1)$ & $50.000(1)$ & 1,396 & 1,229 \\
26 & $100.000(1)$ & $10.000(1)$ & $10.000(1)$ & 1,588 & 1,425 \\
27 & $100.000(1)$ & $50000(1)$ & $100.000(1)$ & 1,185 & 0,880 \\
28 & $500.000(3)$ & $50.000(1)$ & 0 & 1,330 & 0,704 \\
29 & $500.000(3)$ & $250.000(2)$ & $10.000(1)$ & 1,714 & 1,526 \\
30 & $10.000(1)$ & $10.000(1)$ & $10.000(1)$ & 1,337 & 0,946 \\
32 & $100.000(1)$ & $10.000(1)$ & 0 & 1,875 & 0,896 \\
33 & $10.000(1)$ & $100.000(1)$ & $50.000(1)$ & 2,073 & 1,076 \\
34 & 0 & $50.000(1)$ & $100.000(1)$ & 1,511 & 1,120 \\
36 & $100.000(1)$ & $500.000(3)$ & $10.000(1)$ & 1,656 & 1,272 \\
37 & $100.000(1)$ & $10.000(1)$ & $10.000(1)$ & 1,552 & 0,760 \\
38 & $50.000(1)$ & $10.000(1)$ & $50.000(1)$ & 1,948 & 1,333 \\
39 & $10.000(1)$ & 0 & $10.000(1)$ & 1,740 & 1,065 \\
40 & 0 & 0 & 0 & 1,323 & 0,656 \\
\hline
\end{tabular}


TABELA 18 - Contagens de estreptococos mutans antes, 24 horas após 0 primeiro bochecho e uma semana após o último e índices de placa inicial e final para o grupo III (CLOREXIDINA $0,2 \%)$.

\begin{tabular}{cccccc}
\hline CRIANÇA & ANTES & 24h APÓS & 1 SEMANA APÓS & IPI & IPF \\
& & & & & \\
\hline 1 & $50.000(2)$ & $50.000(1)$ & $50.000(1)$ & 1,924 & 1,152 \\
2 & $100.000(1)$ & $100.000(1)$ & $250.000(2)$ & 0.989 & 1,239 \\
3 & $100.000(1)$ & $250.000(2)$ & $500.000(3)$ & 1,273 & 0,409 \\
4 & $10.000(1)$ & $10.000(1)$ & $10.000(1)$ & 1,464 & 0,607 \\
5 & $100.000(2)$ & $50000(1)$ & $100.000(1)$ & 1,260 & 0.596 \\
6 & $250.000(2)$ & $100.000(1)$ & $1.000 .000(4)$ & 1,531 & 1,302 \\
7 & $250.000(2)$ & 0 & 0 & 1,705 & 0.750 \\
8 & $10.000(1)$ & 0 & $10.000(1)$ & 1,365 & 1,202 \\
9 & $100.000(1)$ & $50.000(1)$ & $250.000(2)$ & 1,148 & 0,329 \\
11 & $10.000(1)$ & $100.000(1)$ & 0 & 1,666 & 0,469 \\
12 & $50.000(1)$ & $10.000(1)$ & $100.000(1)$ & 0,950 & 0,750 \\
13 & $1.000 .000(4)$ & $10.000(1)$ & $10.000(1)$ & 1,663 & 1,034 \\
14 & $250.000(2)$ & $10.000(1)$ & $100.000(1)$ & 1,572 & 1,073 \\
15 & $250.000(2)$ & $50.000(1)$ & $100.000(1)$ & 0,974 & 0,592 \\
16 & $50.000(1)$ & $100.000(1)$ & $10.000(1)$ & 1,354 & 0,396 \\
17 & $10.000(1)$ & 0 & $10.000(1)$ & 1,693 & 1,045 \\
18 & $10.000(1)$ & $10.000(1)$ & 0 & 1,489 & 0,369 \\
19 & $100.000(1)$ & $250.000(2)$ & $100.000(1)$ & 1,130 & 0,978 \\
20 & $10.000(1)$ & $50.000(1)$ & $50.000(1)$ & 1,386 & 1,114 \\
\hline
\end{tabular}


TABELA 19 - Contagens de estreptococos mutans antes, 24 horas após 0 primeiro bochecho e uma semana após o último e índices de placa inicial e final para o grupo IV (esteviosídeo 0,5\% associado ao fluoreto de sódio 0,05\% pH 3,4)

\begin{tabular}{|c|c|c|c|c|c|}
\hline CRIANÇA & ANTES & 24h APÓS & 1 SEMANA APÓS & IPI & IPF \\
\hline 61 & $100.000(1)$ & $100.000(1)$ & $100.000(1)$ & 1,454 & 1,786 \\
\hline 62 & $10.000(1)$ & 0 & $10.000(1)$ & 1,793 & 1,793 \\
\hline 63 & 0 & $10.000(1)$ & $10.000(1)$ & 2,031 & 1,893 \\
\hline 64 & $10.000(1)$ & $10.000(1)$ & $100.000(1)$ & 1,916 & 1,562 \\
\hline 65 & $10.000(1)$ & $10.000(1)$ & $250.000(2)$ & 1,823 & 1,469 \\
\hline 66 & $10.000(1)$ & $250.000(2)$ & $250.000(2)$ & 1,818 & 1,807 \\
\hline 67 & $500.000(3)$ & $250.000(2)$ & $500.000(3)$ & 1,250 & 1,521 \\
\hline 68 & $250.000(2)$ & $500.000(3)$ & $250.000(2)$ & 1,045 & 1,204 \\
\hline 69 & $500.000(3)$ & $250.000(2)$ & $500.000(3)$ & 1,562 & 1,333 \\
\hline 70 & 0 & $10.000(1)$ & 0 & 1,458 & 1,417 \\
\hline 71 & $250.000(2)$ & $250.000(2)$ & $10.000(1)$ & 1,636 & 1,454 \\
\hline 72 & 0 & 0 & $10.000(1)$ & 1,798 & 1,812 \\
\hline 73 & 0 & 0 & $10.000(1)$ & 1,391 & 1,304 \\
\hline 74 & $100.000(1)$ & $100.000(1)$ & $250.000(2)$ & 1,594 & 1,708 \\
\hline 75 & $50.000(1)$ & $50.000(1)$ & $100.000(1)$ & 0,771 & 0,729 \\
\hline 76 & 0 & $10.000(1)$ & 0 & 1,469 & 1,687 \\
\hline 77 & 0 & 0 & 0 & 0,969 & 0,875 \\
\hline 78 & $50.000(1)$ & $50.000(1)$ & 0 & 1,522 & 1,177 \\
\hline 79 & $50.000(1)$ & $250.000(2)$ & $500.000(3)$ & 1,398 & 1,000 \\
\hline 80 & 0 & 0 & 0 & 1,708 & 1,719 \\
\hline
\end{tabular}


TABELA 20 - Resultados do teste de Friedman, para efeito de comparações entre as contagens salivares de estreptococos mutans, dos grupos de estudo

\begin{tabular}{ccccc}
\hline \multicolumn{5}{c}{ GRUPOS } \\
& I & II & III & IV \\
\hline \multirow{2}{*}{ ANOVA } & $\mathrm{N}=18, \mathrm{df}=2$ & $\mathrm{~N}=18, \mathrm{df}=2$ & $\mathrm{~N}=19, \mathrm{df}=2$ & $\mathrm{~N}=20, \mathrm{df}=2$ \\
& $\chi^{2}=0,4827$ & $\chi^{2}=4,9375$ & $\chi^{2}=2,7804$ & $\chi^{2}=2,7826$ \\
$\mathrm{p}$ & $<0,7855$ & $<0,0847$ & $<0,2490$ & $<0,24877$ \\
\hline
\end{tabular}




\section{6 - DISCUSSÃO}




\section{6 - DISCUSSÃo}

A discussão foi dividida em 2 partes, seguindo a seqüência dos resultados.

\section{1 - Análise clínica}

Da amostra inicialmente selecionada, no exame do índice de placa inicial, houve uma redução do número de criança por grupo, sendo que a perda foi maior para os grupos I e IV, num total de 8 crianças $(16 \%)$ e, a menor para o grupo III, de 2 crianças (4\%). Registrou-se uma perda final do número total de crianças na ordem de 11,5\% (Tabela 1), o que se considerou baixa. Devido ao fato dos grupos terem sido equilibrados em relação ao índice de placa inicial (I.P.I.) com um desvio-padrão homogêneo, o número de crianças que foram excluídas do estudo não influenciou nos resultados finais, apesar dos grupos I e IV apresentarem perdas maiores quando comparados ao grupo III. Os motivos da perda dos participantes, nos grupos, foram a falta da criança na escola, por não ter sido encontrada na residência ou outros motivos não ligados à pesquisa. Apenas uma criança, no grupo III (digluconato de clorexidina $0,2 \%$ ), não terminou a pesquisa por sentir náuseas, durante os bochechos. 
Com relação à distribuição inicial das crianças nos grupos, pode-se notar uma homogeneidade em relação ao índice de placa inicial (I.P.I.), destacada na Tabela 3. O I.P.I. demonstra a ação da higiene mecânica que os participantes apresentavam previamente à realização dos bochechos e o I.P.F., une esse método à ação dos bochechos com as substâncias testadas. O I.P.I. evidencia que as crianças não apresentavam uma higiene bucal satisfatória, pois os escores médios iniciais para a boca toda apresentaram-se com valores equivalentes à metade do valor máximo possível para o índice usado, como visto por LANG et al. $^{61}$ e ZANELA ${ }^{109}$ que também trabalharam com crianças. FRANCIS; HUNTER; ADDY ${ }^{32}$ pesquisaram em crianças excepcionais e relataram que as mesmas tinham dificuldades com a higiene bucal devido ao próprio problema mental.

As crianças mantiveram os hábitos de higiene bucal habituais e nota-se nas Tabelas 2 e 3, que o grupo I resultou em uma pequena redução do escore médio do índice de placa (4,10\%), talvez devido à ação física do bochecho, entretanto, apresentaram uma maior porcentagem de escore 2 (placa visível), ao final do experimento (de $53,23 \%$ para $54,28 \%$ ). Embora as crianças tenham permanecido com seus hábitos de higiene de rotina, não existiu o efeito placebo para 0 grupo I, como observado nas Tabelas 3, 6, 7 e 8, pois não houve diferença marcante entre os escores médios de placa. Com esses resultados, pode-se utilizar o valor do exame inicial de cada grupo como seu próprio controle, ficando evidenciado que a quantidade de placa acumulada nos grupos II, III e IV, em relação ao grupo I, ao final do trabalho, deveu-se à ação química dos agentes testados. Também pode- 
se dizer, que ao início do tratamento, a placa foi distribuída de acordo com o padrão de higiene bucal das crianças, fato esse também observado por ZANELA ${ }^{109}$.

Outros trabalhos em adultos, nos quais os participantes utilizaram solução placebo, a redução no índice de placa, quando comparada à clorexidina também foi baixa ${ }^{7}, 19,36,39,41,42,49$, 97. Já no trabalho de ZANELA ${ }^{109}$, o grupo placebo mostrou uma redução na ordem de $13,38 \%$, resultado maior do que o registrado neste estudo. A autora relata que foi a manutenção dos hábitos de higiene bucal habituais durante o experimento e ao fato das crianças estarem diariamente sob supervisão para a realização dos bochechos, que pode ter aumentado para esse grupo o efeito da limpeza mecânica, assim como o próprio ato de bochechar. Porém é válido salientar, que apesar da manutenção da higiene bucal das crianças e da supervisão dos bochechos também terem sido realizadas nesta pesquisa, a amostra não foi a mesma e inclusive, observou-se que em uma das escolas escolhidas, a higiene bucal das crianças era melhor, o que poderia ter influenciado a menor redução do escore médio do índice de placa.

A pesquisa foi executada não interferindo com os hábitos de higiene bucal habituais e os de dieta, objetivando-se preservar o efeito das substâncias ativas numa situação a mais real possível de indicação em crianças, da faixa etária estudada. Desse modo, a manutenção da higiene mecânica, por menos que tenha influenciado na redução do

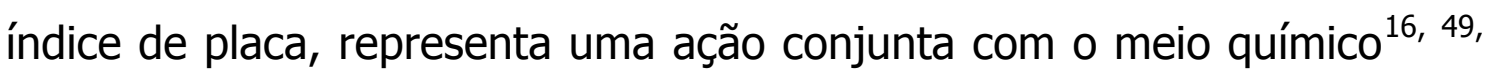
$61,109$. 
O estudo foi desenvolvido por 4 semanas com o objetivo de verificar se os resultados trariam efeito positivo como visto por LÖE et al. ${ }^{65}$ e BRECX et al. ${ }^{16}$, que encontraram ação máxima de utilização da clorexidina nesse intervalo, mesmo empregando metodologias diferentes. Também ZANELA ${ }^{109}$, trabalhando com crianças, durante 6 semanas, encontrou resultados com a solução de digluconato de clorexidina $0,2 \%$ semelhantes a este trabalho e, AXELSON; LINDHE registraram um maior efeito com respeito à redução dos escores de placa, nas primeiras e terceiras semanas de teste. Como na criança, o fator colaboração é de grande importância, a prescrição de uma solução para bochecho por um período de utilização menor, pode ser mais prático.

A maioria dos estudos, anteriormente citados na revisão de literatura, foram desenvolvidos em adultos. Empregar a mesma metodologia para crianças, na faixa etária incluída neste experimento, torna-se difícil devido ao volume da solução utilizada, pois a cavidade bucal é menor. Isso poderia causar o risco de ingestão pela criança, ou da mesma expelir parte da solução ou ainda, não conseguir realizar o bochecho adequadamente. Neste trabalho, o volume de $5 \mathrm{ml}$ foi eficaz na redução da placa, bem como na inserção da solução na cavidade bucal, onde um menor número de riscos, acima citados, foram observados. Isto está de acordo com BIJELLA et al. ${ }^{10}$, que trabalhando com crianças de 7 a 11 anos, testaram a quantidade de líquido expelida após o bochecho com soluções fluoretadas e observaram que o volume de $5 \mathrm{ml}$ foi considerado ideal. Também ZANELA ${ }^{109}$ e BIJELLA et al. ${ }^{11}$ trabalharam com esse volume de $5 \mathrm{ml}$, para verificar a ação antiplaca de bochechos com soluções antimicrobianas e obtiveram resultados satisfatórios, como 
os observados neste estudo. Ainda, WEI; KANELLIS ${ }^{105}$ revelaram que a quantidade ingerida aumentou quanto maior o volume e menor a idade da criança, dando uma interação entre idade/volume.

A freqüência também seria um ponto a ser discutido, visto que a cooperação da criança é primordial, e neste trabalho, os bochechos foram supervisionados de segunda à sexta, sendo que nos finais de semana e nos feriados foram realizados no lar, sem supervisão. Dessa forma, contava-se nesses dias com a colaboração da criança e dos pais e uma menor freqüência, ou seja, uma vez ao dia, seria mais adequado.

A Tabela 2 registra a porcentagem da distribuição dos escores de placa nos diferentes grupos de estudo. As mudanças ocorridas nas superfícies dentárias, em decorrência do uso das substâncias, pode ser observada através desses valores, que em geral, pode-se dizer seguiu uma ordem decrescente: uma possível mudança do escore 2 para o 1 e do 3 para o 2 ou 1 . Nesse trabalho não se registraram alterações do escore 3 para o 0 , até porque as anotações desse escore foram menos freqüentes. Esse fato, de modificação decrescente dos escores, também foi observado por LANG et al. ${ }^{61}$, que relataram também as variações ocorridas com os escores 2 e 1 ao final do estudo, da mesma forma. 0 escore 0 que representa superfície dentária livre de placa detectável clinicamente, apresentou porcentagens iniciais que variaram de 5,58\% a $6,39 \%$. Após as 4 semanas do experimento, em comparação ao exame inicial, observa-se um aumento nesses valores para os grupos. Destacase uma efetividade das soluções dos grupos II e III, pela representação do aumento do escore 0 e diminuição do escore 2 e 3 de uma forma mais evidente. 
O grupo II mostrou um aumento considerável no registro de escore 0 (de 5,58\% para 21,98\%) e no escore 1 (de 37,01\% para $45,57 \%$ ) e simultaneamente, uma redução nos escores 2 e 3.0 mesmo ocorreu para o grupo III, que utilizou o digluconato de clorexidina $0,2 \%$ e resultou numa porcentagem de escore 0 e 1 na ordem de $35,92 \%$ e $41,92 \%$, respectivamente. Concomitantemente, reduziu as porcentagens de escore 2 e 3 que são anotados quando da presença clinicamente observada, de placa dentária.

Isso confirma a ação antiplaca das soluções dos grupos II e III e o seu valor para aplicação clínica em situações específicas, na criança, a qual exija maior controle no acúmulo de placa dentária. Essa efetividade fica relevante pela análise da redução dos escores médios de placa, tanto para a boca toda como para as faces dentárias (Tabelas 3, 6 , 7 e 8 e figuras 4 a 8). EATON et al..$^{26}$ utilizando clorexidina $0,12 \%$, em adultos, verificaram que após 12 semanas, os escores de placa tornaramse 0 ou 1 num total de 1714, dando uma redução de 54,5\% e LANG et al. ${ }^{61}$, trabalhando com crianças, relataram a efetividade da clorexidina, nos diversos regimes, com relação ao aumento dos registros de escore 0 e diminuição dos escore 2 e 3.

O grupo IV manteve também um aumento dos escores $0 \mathrm{e}$ 1, com diminuição dos escores 2 e 3, ao final do estudo, embora numa percentagem muito menor que os grupos II e III. Isso, talvez, seja pelo fato da pouca efetividade observada nesse grupo.

É importante relevar que a porcentagem dos escores no início do trabalho, em relação à sua distribuição, foi semelhante para os 4 
grupos, confirmando o padrão habitual de higiene bucal das crianças que era equilibrado.

Os resultados na redução do índice de placa para a boca toda, descritos na Tabela 3 e figuras 4 e 5, foram de 26,75\%; $41,20 \%$ e $5,91 \%$ para os grupos II, III e IV, respectivamente, o que comprova a ação das soluções dos grupos II e III em diminuir a formação de placa dentária, mesmo que em níveis diferentes. Presumivelmente, componentes antibacterianos salivares agem melhor contra placa dentária dispersa, comparada àquela organizada com várias camadas. Quando um bochecho pode reduzir o desenvolvimento da placa, por manter baixo o número de bactéria viável, os compostos químicos e salivares podem agir sinergicamente. Assim, a somatização da higiene bucal mecânica e a ação química, oferece eficiência porque a quantidade de placa é reduzida, tornando-a desorganizada e/ou fina, podendo ser mais facilmente removida ${ }^{78}$.

Analisando o grupo II, observa-se uma redução estatisticamente significante do escore médio final de placa para 1,122 (Tabela 3 e figura 4), equivalendo a 26,75\% (Tabela 3 e figura 5), o que demonstra a eficiência de inibição de placa nesse grupo. A ação da clorexidina associada ao fluoreto de sódio sobre a placa e a cárie dentária foi comprovada por estudos na literatura $47,49,66,67,69,70,71$. Reduções nos escores de placa em torno de $40 \%$ a $50 \%$, foram verificadas por JENKINS; ADDY; NEWCOMBE ${ }^{47}$, JOYSTON-BECHAL; HERNAMAN ${ }^{49}$, LUOMA et al. ${ }^{69}$ e MENDIETA et al. ${ }^{74}$ Nota-se que as reduções no acúmulo de placa foram maiores que a relatada neste trabalho que foi de $26,75 \%$, 
porém há de se ressaltar que os regimes empregados foram diferentes, com freqüência e volumes maiores.

Outra investigação de LUOMA et al. ${ }^{70}$ evidenciou que foi possível reduzir simultaneamente, e significantemente, cárie e gengivite com aplicações de clorexidina $0,05 \%$ e flúor $0,044 \%$. E a escovação supervisionada antes e durante o estudo pode ter servido como uma somatória na redução da quantidade de placa. Os autores ${ }^{70}$ sugerem que as reduções obtidas com essa combinação não foram, provavelmente, a clorexidina sozinha devido à baixa concentração empregada e sim as duas substâncias, pois o pH da solução $(5,8)$ promoveria a ação inibitória do flúor contra a bactéria bucal. Outro estudo, também, encontrou uma tendência a menor incidência de cárie, embora não estatisticamente significante, em crianças que bochecharam com solução contendo clorexidina e flúor do que quando bochecharam com a clorexidina sozinha9.

Os dados deste trabalho, em relação ao digluconato de clorexidina $0,2 \%$ (grupo III), que apresentou escore médio final de 0,866 (figura 4), e redução percentual de placa para a boca toda de $41,20 \%$ (figura 5), estão de acordo com outros estudos realizados com bochechos de clorexidina, embora em porcentagens, frequências de uso e volumes diferentes, que também preveniram a formação de placa dentária e apresentaram redução percentual próxima aos resultados desta pesquisa ${ }^{7}$, 39,59,65,74,80,81,85,86 apesar das metodologias diferentes e de serem realizados em adultos. Outros autores, registraram valores maiores de redução percentual ${ }^{6,8,16,30,37,41,63,64,97}$ ou reduções menores ${ }^{2,7,12,13,26,35,36,101}$. 
O trabalho de LANG et al. ${ }^{61}$, com crianças entre 10 e 12 anos, aplicando regime de bochechos diários com clorexidina a $0,2 \%$ ou 0,1\%, 6 vezes na semana, mostrou escore médio de placa, em 6 meses de pesquisa, equivalente a 1,2414 e 1,2912, respectivamente. A redução percentual, utilizando $15 \mathrm{ml}$ de clorexidina $0,2 \%$, foi de $19,4 \%$. Esses dados são inferiores aos obtidos nesta pesquisa, cujo escore médio de placa para a boca toda foi de 0,866 e redução percentual de $41,20 \%$, 0 que demonstra a eficiência do método utilizado. Entretanto ZANELA ${ }^{109}$ encontrou reduções no escore médio de placa de 0,758 e 52,63\% de redução percentual, utilizando clorexidina $0,2 \%$ durante 6 semanas, empregando o mesmo regime que esta pesquisa, em crianças da mesma faixa etária. Os resultados deste trabalho e do estudo de ZANELA ${ }^{109}$, confirmam que o emprego dessa substância, na forma de bochechos, em crianças, é possível e capaz de reduzir o acúmulo de placa dentária, favorecendo a saúde bucal do paciente, quando indicado. Apesar de não ter ocorrido uma redução total no índice de placa das crianças, sabe-se que a clorexidina atua sobre as funções dos microrganismos ${ }^{28}$, especificamente estreptococos mutans, por essa razão pode-se esperar a formação de uma placa mais fina ou um retardo no desenvolvimento da mesma, podendo refletir significantemente no índice de placa, como visto nesta pesquisa.

Para o grupo IV, que bochechou com a solução de esteviosídeo 0,5\% associado ao fluoreto de sódio $0,05 \% \mathrm{pH} 3,4$, a redução no acúmulo de placa para a boca toda foi de 5,91\% (figura 5 e Tabela 3), apresentando I.P.F. de 1,431 (figura 4 e Tabela 3). Trabalhos clínicos com bochechos, utilizando soluções contendo esteviosídeo tanto 
em crianças $^{11,} 109$ quanto em adultos ${ }^{96}$, evidenciaram reduções no acúmulo de placa dentária. SLAVUTZKY; SCARPINI ${ }^{96}$ registraram uma redução no índice de placa de 57,82\% e ZANELA ${ }^{109}$ encontrou redução, estatisticamente significante na ordem de $30,60 \%$. Esses dados foram bem maiores que os encontrados neste trabalho, entretanto no experimento de SLAVUTZKY; SCARPINI ${ }^{96}$, a freqüência de utilização (4 vezes ao dia) assim como a concentração (10\%) foram maiores. A concentração de $10 \%$ teria uma aplicabilidade difícil em crianças, já que o sabor amargo provavelmente se acentuaria, dificultando seu emprego. No trabalho de ZANELA, o esteviosídeo foi utilizado a $0,1 \%$, sem adição de flúor e pH neutro, por 6 semanas. Entretanto, com relação ao pH da solução utilizada $(3,4)$, segundo GOTO; $\operatorname{CLEMENTE}^{38}$, o esteviosídeo não se altera, visto que essa substância é estável a uma ampla faixa de $\mathrm{pH}$ (entre 2,0 e 10). Também, apesar de PINHEIRO et al. ${ }^{84}$ considerar que o esteviosídeo apresenta baixa solubilidade em água, quando em temperatura ambiente (e a concentração empregada neste trabalho foi de $0,5 \%$, com as soluções mantidas em temperatura ambiente), segundo GOTO; CLEMENTE ${ }^{38}$, a solução foi preparada para que nessa concentração e condição se mantivesse solúvel. Além disso, o esteviosídeo $0,5 \%$ demonstrou ação antiplaca no trabalho de $\mathrm{CHEDID}^{17} \mathrm{e}$ anticariogênico nas pesquisas de DAS et al. ${ }^{22}$, de $\operatorname{KLEBER}^{55}$ e de OLIVEIRA et al. ${ }^{79}$ CORRÊA; ROSSONI; MALTZ ${ }^{20}$ também não encontraram desmineralização clínica em esmalte quando esse era exposto ao esteviosídeo 0,2\%. Já KLEBER ${ }^{55}$ relata que a severidade da lesão de cárie dentária não foi influenciada pela solução de esteviosídeo 0,5\%, a qual foi incapaz de reduzir a extensão das lesões que se formaram tanto em 
superfície lisa como nas fissuras. Ao contrário da associação do fluoreto de sódio 0,02\% com o esteviosídeo 0,5\% que, de forma significante, diminuiu a severidade das lesões. Isto indicou, segundo o autor, que uma vez a lesão instalada, o esteviosídeo foi incapaz de inibir ou reverter (via remineralização), o processo da cárie.

A associação do estudo ao fluoreto de sódio 0,05\%, numa solução com pH 3,4, foi feita pelo fato desta última substância, sozinha, ter apresentado ação antiplaca, em crianças ${ }^{10,109}$. E como o trabalho de BIJELLA et al. ${ }^{11}$, empregando a mesma solução de esteviosídeo deste trabalho, registrou uma redução percentual de $23,82 \%$ no índice de placa, num período de 3 semanas de pesquisa, houve interesse para comparações com outros agentes antimicrobianos.

É interessante ressaltar, entretanto, que a solução pode ter sido alterada durante o uso, por não ter sido empregado um conservante, como foi no estudo de BIJELLA et al. ${ }^{11} \mathrm{e}$ isso, pode ter prejudicado sua ação sobre a placa, já que os autores acima citados, apresentaram melhores resultados.

Apesar dos resultados deste estudo não evidenciarem uma redução quantitativa através do índice de placa, BERRY; HENRY ${ }^{9}$ e YABU et al. ${ }^{101}$ demonstraram a não metabolização dessa substância por microrganismos bucais, especificamente o $\mathrm{S}$. mutans demonstrando seu efeito antiplaca. Também CHEDID ${ }^{17}$ e PINHEIRO et al. ${ }^{84}$, trabalhando com placa humana "in vitro", demonstraram sua ação no metabolismo bacteriano. Segundo CHEDID $^{17}$, o esteviosídeo apresenta uma composição bioquímica semelhante à sacarode e com isso exerceu um 
certo efeito competitivo com a mesma, resultando uma ação sobre a queda do pH e produção de ácidos.

Os resultados estatísticos entre os grupos testados, observados na Tabela 4, demonstra que houve diferenças estatisticamente significantes do efeito do tratamento para os grupos, porém, ao realizar as comparações individuais (Tabela 5), observou-se que essa diferença existiu quando os grupos II e III foram comparados com os grupos I e IV. Entretanto, o grupo II (gluconato de clorexidina 0,12\% associado ao fluoreto de sódio 0,05\%) não mostrou diferença estatisticamente significante em relação ao grupo III (digluconato de clorexidina 0,2\%), neste trabalho. Apesar desse fato ter ocorrido, observa-se que em termos percentuais, o grupo III $(41,20 \%)$ revelou um melhor resultado que o II (26,75\%), em termos de redução do acúmulo de placa para a boca toda. Isso está de acordo com MENDIETA et al. ${ }^{74}$ que também evidenciaram uma redução maior no índice de placa para a solução de clorexidina $0,12 \%$ sem flúor, em comparação à solução associada ao fluoreto de sódio. E os autores relataram que poderia ter ocorrido uma redução na disponibilidade da clorexidina na solução associada ao fluoreto de sódio, apesar das concentrações das soluções nos dois estudos serem diferentes. A solução de esteviosídeo 0,5\% associada ao fluoreto de sódio $0,05 \% \mathrm{pH} \mathrm{3,4}$ foi a que apresentou menor redução de placa em relação a de gluconato de clorexidina associada ao fluoreto de sódio $0,05 \%$ e a de digluconato de clorexidina $0,2 \%$.

As faces dentárias também foram avaliadas (Tabelas 6 a 13), pois EATON et al. ${ }^{26}$ sugerem que o uso de escores para a boca toda 
podem mascarar as variações locais em diferentes áreas da boca, no acúmulo de placa dentária.

$\mathrm{Na}$ face vestibular obteve-se uma média de I.P.F. de 1,$102 ; 0,776$ e 1,436 e uma redução percentual de $28,67 \%, 48,01 \%$ e $5,71 \%$ para os grupos II, III e IV, respectivamente (Tabela 6 e figura 6). Considerando a face lingual, a média do I.P.F. foi de 1,027; 0,806 e 1,265 e a redução percentual de $25,76 \% ; 41,21 \%$ e 10,54\%, para os mesmos grupos experimentais e na mesma ordem (Tabela 7 e figura 7). Ainda para a mesma seqüência de grupos, as faces proximais resultaram uma média do I.P.F. de 1,181; 0,866 e 1,511, sendo a porcentagem de diminuição de $26,18 \% ; 44,95 \%$ e 4,16\% (Tabela 8 e figura 8 ).

Para o grupo II, as faces vestibular, lingual e proximais, praticamente, tiveram as mesmas reduções de placa. Avaliando-se as Tabelas 10 e 13, observa-se que nesse grupo não houve diferença estatisticamente significante na redução do acúmulo de placa entre as faces. O difícil acesso à superfície proximal torna esa área mais díficil para limpeza e por isso uma interação mais restrita do agente é esperada, apesar de ter-se dado orientação para realização do bochecho com vigor, a fim de que o líquido penetrasse nessa região. Assim vale salientar uma importante ação nessas superfícies. JENKINS; ADDY; NEWCOMBE ${ }^{47}$ também encontraram semelhante diminuição no índice de placa nas superfícies vestibular e lingual quando da utilização da clorexidina associada ao flúor, apesar da utilização de um índice de placa diferente, o que restringe maiores comparações. Os autores ainda destacaram que segundo as informações clínicas, o fluoreto de sódio causou pouca ou nenhuma interferência com a atividade da clorexidina. 
Considerando o grupo III, houve uma maior redução de placa nas faces vestibular vindo a seguir as proximais e depois a lingual. Existiu diferença estatisticamente significante entre a face vestibular com a distal e lingual e também da lingual com a mesial (Tabelas 11 e 13). ZANELA $^{109}$, trabalhando com crianças, utilizando metodologia semelhante, encontrou após 6 semanas de pesquisa, semelhante redução de placa nas superfícies vestibular $(56,48 \%)$ e lingual $(56,13)$, vindo a seguir a face distal $(52,02 \%)$ e, depois, a mesial $(45,50 \%)$. As diferenças estatisticamente significantes foram relatadas entre as faces vestibular com proximais e lingual com mesial. Salienta-se, que as faces vestibular e lingual foram as mais interagidas com os bochechos. Apesar das reduções de placa nas faces dentárias terem sido menores neste trabalho, o índice de placa inicial das crianças também eram menores que no estudo acima citado, com exceção das superfícies proximais. E observa-se, também, uma melhor ação na face vestibular em relação à lingual, o que a destaca com maior redução percentual. Outras pesquisas, porém em adultos, registraram maiores reduções no acúmulo de placa nas superfícies vestibular e lingual e menores reduções nas proximais, como os de AXELSSON; LINDHE $^{7 \prime}$ e CUMMING; LÖE ${ }^{21}$. Já HASE et al. ${ }^{42}$ e LÖE et al. ${ }^{65}$ verificaram queda no índice de placa na utilização de bochechos com gluconato de clorexidina $0,2 \%$, especialmente nas faces proximais, porém há de se relevar que os participantes do primeiro estudo eram estudantes de medicina e os do segundo, também eram adultos.

ZICKERT; EMILSON; KRASSE $^{110}$, trabalhando com digluconato de clorexidina a $1 \%$, em gel, também em crianças, 
encontraram maiores reduções no número de novas lesões de cárie nas superfícies vestibular e lingual; eles salientaram que a redução no nível de estreptococos mutans pode ter favorecido a remineralização de lesões iniciais de esmalte e ter retardado o desenvolvimento de novas lesões.

Analisando o grupo IV, pode-se verificar que a redução de placa apresentou um valor percentual maior para a face lingual, seguida da vestibular e por último as proximais. Nas Tabelas 12 e 13 observa-se que, apenas, houve diferença estatisticamente significante entre a face lingual e a distal. Pode-se dizer que esse resultado não é relevante, visto que o grupo de uma forma geral não apresentou reduções de placa de forma efetiva. No trabalho de ZANELA ${ }^{109}$ que empregou o esteviosídeo $0,1 \%$ em crianças, com metodologia semelhante, os resultados foram satisfatórios na inibição da placa, especialmente na interproximal, o que foi considerado um fator importante, pois essa área é de difícil acesso, principalmente pelas crianças. A autora encontrou redução percentual em ordem decrescente de valor, nas faces vestibular $(32,19)$, distal $(30,27 \%)$, mesial $(26,85 \%)$ e finalmente a lingual $(24,71 \%)$.

Apesar da solução de esteviosídeo, neste estudo, não ter apresentado estatisticamente uma redução de placa significante (Tabelas 4 e 5), há segurança na sua utilização em crianças, inclusive se houver deglutição, por ser uma substância natural ${ }^{1,106}$. E como existe registro da ação positiva dessa substância, em crianças, novas pesquisas devem ser elaboradas com o esteviosídeo, procurando utilizar sempre um conservante adequado para torná-lo mais estável e também estudá-lo em combinação com os fluoretos, visando sua aplicabilidade clínica. 
$\mathrm{Na}$ Tabela 14, encontram-se os dados relacionados às respostas obtidas do questionário aplicado às crianças e os valores da presença de pigmentação, anotados pela examinadora. Nele podem-se coletar informações importantes referentes aos efeitos colaterais e aceitação do método empregado neste estudo.

Para o grupo II (gluconato de clorexidina $0,12 \%$ associado ao fluoreto de sódio 0,05\%), o sabor amargo foi evidenciado por 3 crianças, sendo que 6 sentiram sabor ardido. O grupo III (digluconato de clorexidina $0,2 \%$ ) foi o de maior referência para esses sabores, que foi de 23 crianças para o sabor amargo e no grupo IV (esteviosídeo 0,5\% associado ao fluoreto de sódio 0,05\% pH 3,4), 15 crianças o consideraram amargo e duas azedo. Quanto à opinião sobre o sabor das soluções no grupo II, 5 crianças relataram que o bochecho foi ruim; 11, mais ou menos e 31, agradável. Entretanto no grupo I (controle) também houve registros de sabor amargo e ardido que foram de 4 e 5, respectivamente, o que demonstra que as crianças se sensibilizam a diferentes sabores, visto que a água deionizada foi mentolada. Isso mostra que a introdução de um sabor pode diversificar a opinião, pois ZANELA $^{109}$, utilizando água deionizada pura, verificou em seu trabalho que todas as crianças relataram a solução como agradável. Neste trabalho inseriu-se o sabor menta, visto que no de ZANELA ${ }^{109}$, as crianças apesar de acharem o sabor agradável queriam utilizar as outras soluções testes, pois reconheciam o sabor como sendo de água e esse fato muitas vezes desestimulava o grupo. 0 grupo III evidenciou que 20 crianças consideraram que o bochecho foi mais ou menos e 9 o acharam agradável, sendo que 14 participantes desse grupo o citaram como ruim. 
No grupo IV, a solução foi agradável para 14 crianças, mais ou menos para 17 e 5 relatos para a sensação de ruim. Na figura 9 pode-se verificar melhor a aceitação dos bochechos pelas crianças, em relação ao seu grupo experimental, sendo que, com exceção do grupo III, para as demais a opinião predominante foi positiva. Isso revelou a confiabilidade das respostas, a solução usada (Plak-out) tem, sabor bastante forte e até desagradável para alguns. O trabalho de ZANELA ${ }^{109}$ também de fato, destacou essa mesma solução como a menos aceita pelas crianças.

Efeitos colaterais têm sido relatados com a utilização da clorexidina tanto na concentração de $0,2 \%$ quanto na de $0,12 \% 6,8,16,19$, $21,30,36,39,41,61,63,65,74,80,101$, apesar desses trabalhos terem sido desenvolvidos em adultos, com metodologias diferentes. No trabalho de HASE et al. ${ }^{41}$, os participantes registraram, em sua maioria, a opinião de "muito ruim" no grupo que utilizou digluconato de clorexidina $0,2 \%$, em bochechos. LACAZ-NETTO et al. ${ }^{59}$ afirmaram que na utilização de bochechos com clorexidina, um sabor mais intenso era detectado. BELLINI et al. ${ }^{9}$ também constataram que esse efeito foi mais relatado com os bochechos do que com aplicação tópica. Já SMITH et al. ${ }^{97}$ relataram que nenhum efeito colateral foi comentado em relação ao sabor amargo ou distúrbio do paladar pelos participantes do trabalho, ou notados pelo examinador clínico. E ainda, MORAN; ADDY; ROBERTS ${ }^{76}$, também não encontraram efeitos indesejáveis.

As soluções que contêm clorexidina, segundo KIDD ${ }^{53}$ apresentam paladar amargo que pode ser mascarado com anis e hortelã. Apesar da solução de PLAK-OUT conter o flavorizante anis, a maioria das crianças do grupo III considerou a solução como ruim $(32,56 \%)$ ou mais 
ou menos $(46,51 \%)$, como pode se observar na figura 9. Como as crianças necessitam de estímulo, para motivá-las a colaborar com 0 bochecho, o sabor agradável de uma solução seria um excelente atrativo já que a clorexidina teve menor aceitação pelas crianças, devido ao seu sabor.

Outros estudos, utilizando essa substância em menor concentração revelaram perda de pacientes ${ }^{26,80,94}$, com razões associadas a efeitos colaterais do produto. No trabalho de SEGRETO et al. ${ }^{94}$, observou-se uma perda de pacientes maior no grupo que bochechou com clorexidina $0,2 \%$ em relação à substância a $0,1 \%$. Cerca de $12 \%$ saíram do grupo que utilizou a concentração $0,2 \%$ contra $4 \%$ dos pacientes dos grupos da clorexidina 0,1\% e placebo. Apesar da pequena diferença, pode-se esperar melhor aceitação com bochechos de clorexidina menos concentrados. Neste estudo houve perdas de $10 \%$ (5 crianças) no grupo II e de 4\% ( 2 crianças) no grupo III; entretanto apenas uma criança do grupo III apresentou problemas relacionados ao sabor, pois sentia náuseas durante os bochechos.

O amargo também foi detectado pelas crianças do grupo IV, num total de 15 crianças (Tabela 14), confirmando os achados de YAMAMOTO et al. ${ }^{108}$. No caso do esteviosídeo, este produto apresenta uma molécula intrínseca responsável por essa sensação. Segundo DUBOIS; STEPHENSON ${ }^{25}$, a substituição dessa molécula atenuaria esse inconveniente. A solução também continha um pH acidulado e assim, pode também ter interferido no sabor, pois no trabalho de ZANELA ${ }^{109}, 7$ crianças, num total de 41 , também registraram esse sabor quando bochecharam com fluoreto de sódio $0,05 \% \mathrm{pH} 3,4$. O trabalho de 
SLAVUTZKY; SCARPINI ${ }^{96}$ também mostrou relatos de sabor desagradável com o uso de estévia $10 \%$.

Outros efeitos colaterais como auteração do paladar e alteração no sabor dos alimentos foram registrados nos grupos II e III. No grupo II, 6 crianças (12,76\%) relataram alteração no paladar e 5 $(10,64 \%)$ evidenciaram alteração no sabor dos alimentos. Para o grupo III, esses valores para os mesmos registros foram de $24(55,81 \%)$ e 17 $(39,53 \%)$, respectivamente, sendo em ambos os grupos, passageira. Esse mesmo efeito foi descrito por LANG et al. ${ }^{61}$ : havia uma mudança seletiva na percepção do gosto para o cloreto de sódio, sendo sempre registrada após o primeiro bochecho do dia, regredindo após cessar o procedimento, durante o período experimental. Outros autores, como ASIKAINEN et al. ${ }^{6}$, BELLINI et al. ${ }^{8}$, COLLAERT et al. ${ }^{19}$, ETEMADZEDEH et al. ${ }^{30}$, HASE et al. ${ }^{41}$, HILDEBRANDT ${ }^{44}$ e LACAZ NETO et al. ${ }^{59}$, também referenciaram a alteração do paladar, apesar das metodologias empregadas serem diferentes e os trabalhos desenvolvidos em adultos. ASIKAINEN et al. ${ }^{6}$ relataram que o digluconato de clorexidina $0,2 \%$ diluído do Plak-Out ocasionou uma perda de sensação do paladar mais freqüente, o que explicaria a porcentagem de relatos de alteração do paladar neste trabalho. Esses resultados têm relevância clínica, significando que a clorexidina seria melhor utilizada após as refeições ou à noite, antes de deitar (LANG; BRECX ${ }^{60}$ ). Também GJERMO ${ }^{35}$ relata, em uma revisão, a alteração da sensação do paladar principalmente na percepção do doce e salgado e explica que essa interferência ocorre pela desnaturação das superfícies das proteínas. Assim, talvez, soluções em menores concentrações possam oferecer vantagens na aceitação do 
paladar, como pode ser observado na Tabela 14, no grupo II, em comparação com o grupo III, apesar da redução percentual no índice de placa para o grupo II ser de $26,75 \%$ e para o grupo III, ser de $41,20 \%$ (Tabela 3).

Outros efeitos causados pela substância dos grupos II e III, como irritação, secura da mucosa ou ardência, não foram evidenciados durante o exame clínico final e nem relatados pelas crianças que participaram deste trabalho, provavelmente pelo volume da solução utilizado ser de $5 \mathrm{ml}$ e a freqüência ter sido diária. SEGRETO et al. ${ }^{94}$ também não encontraram diferença no exame dos tecidos moles que indicassem efeitos adversos da clorexidina apesar de serem diferentes as metodologias. O mesmo não ocorreu nos experimentos de ASIKAINEN et al. ${ }^{6}$ e de AXELSSON; LINDHE$^{7}$, quando alguns participantes apresentaram lesões na mucosa, inclusive com desistência de participação no trabalho e no de HILDEBRANDT ${ }^{44}$ que evidenciou uma sensação de queimação na boca e língua, com tendência a diminuir em sessões subseqüentes. COLLAERT et al. ${ }^{19}$ registraram dados relacionados à sensação de boca anestesiada, porém passageira, de maneira semelhante ao obtido nesta pesquisa, pelas crianças do grupo III.

Quanto à presença de pigmentação, as manchas de coloração marrom-castanho, foram anotadas no exame clínico final (Tabela 14), quando verificou--se a presença das mesmas nos grupos II e III, em $14,89 \%$ e $27,91 \%$, respectivamente, sendo de intensidade suave, e apenas uma criança do grupo II e 3 do grupo III as perceberam nos dentes anteriores. Esse efeito colateral foi o mais detectado na maioria dos estudos com clorexidina, tanto em 


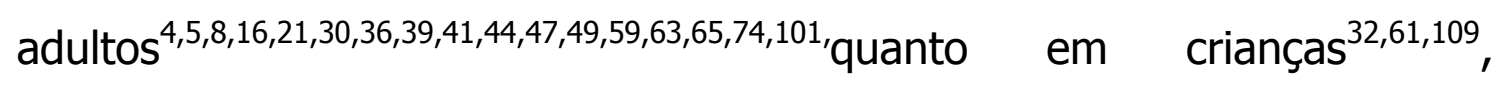
apesar das metodologias dos trabalhos serem distintas. ZANELA ${ }^{109}$ detectou esse efeito colateral em 34,69\% das crianças que utilizaram digluconato de clorexidina $0,2 \%$ e estas, também, foram de intensidade suave e apenas 8 crianças as perceberam, com localização nos dentes anteriores. Os dados do trabalho de ZANELA ${ }^{109}$ foram um pouco maiores que deste estudo, porém a localização foi semelhante. E isso pode ter ocorrido porque apesar do regime de bochechos ter sido igual, o tempo de trabalho nesta pesquisa, foi menor. Segundo $\mathrm{KIDD}^{53}$, o efeito mais problemático da clorexidina é a pigmentação dentária e existe uma relação direta entre pigmentação, freqüência de uso e dose de exposição a essa substância. No trabalho de LÖE et al. ${ }^{65}$ realizado a longo prazo, associado à higiene bucal, a pigmentação dentária foi o único efeito colateral detectado. E no estudo de $\operatorname{LUOMA}^{70}$, também longitudinal, as crianças que bochecharam e escovaram com solução e dentifrício contendo clorexidina $0,05 \%$ e fluoreto de sódio $0,04 \%$, mostraram pouca pigmentação ao final de 2 anos.

Segundo JENKINS, ADDY; NEWCOMBE ${ }^{47}$, produtos contendo clorexidina em menor concentração podem oferecer vantagens na aceitação do paladar e possibilidade em reduzir irritação na mucosa bucal, entretanto a diminuição na incidência de pigmentação não é esperada e este trabalho está de acordo com esses relatos. Os autores, acima mencionados, no exame clínico da pesquisa, anotaram que 49\% dos pacientes tinham pigmentação dentária e cerca de $82 \%$ conseguiram detectá-la, em relação ao grupo controle. Observa-se que os dados são maiores, porém enfatiza-se que a metodologia empregada foi diferente, 
aplicando-se maiores volumes e tempo maior de utilização sendo o estudo realizado em adultos. Já SPETS-HAPPONEN et al. ${ }^{99}$, empregando uma solução de clorexidina e flúor, em menor concentração que este trabalho, utilizando o mesmo volume $(5 \mathrm{ml})$, porém duas vezes ao dia, também registraram resultados semelhantes ao encontrado aqui, relatando a presença de pigmentações, em dentes, bem suaves e até negligenciáveis.

Pelos resultados deste trabalho, as substâncias dos grupos II e III reduziram a formação de placa bacteriana. A solução de digluconato de clorexidina $0,2 \%$ foi eficaz na redução de placa em $41,20 \%$, porém causou maiores efeitos colaterais, apesar desses terem sido em grande parte aceitáveis pelas crianças, como a presença de manchas. A solução de gluconato de clorexidina $0,12 \%$ associada ao fluoreto de sódio 0,05\% também reduziu placa de forma significante em relação ao grupo controle, mas em valores percentuais menores $(26,75 \%)$; entretanto, os efeitos colaterais, apesar de presentes, foram bem inferiores que os da solução do grupo III. Assim, tanto a solução de digluconato de clorexidina $0,2 \%$ quanto a solução de gluconato de clorexidina $0,12 \%$ associada ao fluoreto de sódio $0,05 \%$ podem ser recomendadas como auxiliares na redução de placa, dependendo seu emprego das diferentes situações de uso e necessidades clínicas, sendo importante novas investigações para consolidar seu uso em Odontopediatria. O esteviosídeo 0,5\% associado ao fluoreto de sódio 0,05\% pH 3,4 não apresentou uma porcentagem de redução de placa evidente e estatisticamente significante em relação ao controle. Porém, por ser uma substância natural, não oferecendo riscos em casos de 
deglutição pela criança e já ter apresentado ação antiplaca em outros trabalhos clínicos ${ }^{11,109}$, necessita de mais pesquisas para definir a sua concentração e a sua associação com o fluoreto de sódio, a fim de que se prove e aprimore sua aplicação.

\section{2 - Análise Microbiológica}

No exame microbiológico, assim como se observou no grupo todo, houve perdas: uma criança do grupo III (10) iniciou tratamento ortodôntico no decorrer do trabalho e duas dos grupos I (48 e 5) e II (31 e 35) foram eliminadas por não seguirem adequadamente o regime de bochechos (Tabela 15). Nas Tabelas 16 a 19 estão registradas as contagens de estreptococos mutans salivares feitas nas crianças, no início da pesquisa, 24 horas após o primeiro bochecho e uma semana após o último bochecho. A contagem realizada 24 horas após o primeiro bochecho visava observar o efeito imediato das soluções testadas e aquela após uma semana do último bochecho, o efeito residual do tratamento ${ }^{98,99}$.

Sabe-se que os estreptococos mutans constituem o principal grupo de microrganismos associados à lesão de cárie dentária ${ }^{57}$, especialmente com o seu início. Assim, a quantificação dessas bactérias juntamente com outros fatores como dieta e hospedeiro é um parâmetro útil na avaliação do risco de cárie de um paciente. É relevante destacar que a avaliação microbiológica deve ser feita com bom senso, considerando suas limitações. A contagem desses microrganismos na 
saliva é mais um exame complementar a ser considerado na prevenção e tratamento da cárie dentária, pois a deteç̧ão dessa bactéria pode indicar um ambiente potencialmente cariogênico ${ }^{14}$.

O exame microbiológico pode ser indicado para: comprovar o diagnóstico de alto risco, dado por outros fatores; avaliar o risco em crianças sem experiência passada de cárie; avaliar o efeito de medidas dietéticas e antimicrobianas; selecionar pacientes com alto risco de cárie em saúde coletiva; determinar o grau de infecção de pacientes que irão receber extensos trabalhos odontológicos; detectar indivíduos que possam agir como possíveis fontes de infecção; motivar e monitorar pacientes ${ }^{88}$. Como pode-se verificar, a avaliação do efeito de soluções antimicrobianas é uma das indicações, por esse fato ela foi incorporada ao presente trabalho, juntamente com o exame do acúmulo de placa.

Para a avaliação microbiana foi utilizada saliva total estimulada, que durante a coleta permite o deslocamento dos microrganismos dos dentes, mostrando-se representativa da microbiota presente na boca toda ${ }^{57,88}$, e foi eleito o CARITEST SM, teste semiquantitativo que fornece o número aproximado dos microrganismos, ao invés de teste tradicional, pela facilidade de manipulação e uso pelos clínicos. Em função de falhas no Controle de Qualidade desses testes, procuramos eliminar aqueles que exibissem volumes diferentes para os tampões, ou que apresentassem camadas inadequadas de ágar, sem mencionar os contaminados. Tomamos o cuidado ainda de padronizar o volume de saliva em $1,5 \mathrm{ml}$.

A literatura tem demonstrado que as substâncias testadas neste trabalho, a clorexidina associada ou não ao fluoreto de sódio e o 
esteviosídeo, atuam sobre os microrganismos bucais $^{2,4,9,17,19,22,27,30,41,44,48,50,66,67,73,77,87,90,92,93,98,99,103,107,110}$. Todavia, nesta pesquisa as contagens de estreptococos mutans na saliva não revelaram diferença estatisticamente significante entre as três etapas para os três tipos de tratamento, registrando-se para o grupo $I, p<0,7855$, para 0 grupo II, $p<0,0847$, para o grupo III, $p<0,2490$ e para o grupo IV, $p<0,2487$ (Tabela 20).

No grupo I, a única criança que apresentou um resultado final satisfatório nas contagens de estreptococos mutans foi a de número 44, como observado na Tabela 16, apesar do I.P.F. ter-se mantido estável. Pode-se explicar esse fato, especificamente nessa criança, apesar da solução bochechada não conter ingrediente ativo, que 0 ato de bochechar pode ter auxiliado na desorganização da placa, e assim ter atuado sobre essas bactérias. A variação nas contagens, vistas dentro deste grupo, talvez nos ajude a entender por que as variações nos grupos tratados não puderam ser considerados significantes.

No grupo II, as crianças de números 22, 25, 28 e 29 (Tabela 17) apresentaram uma redução importante nas contagens dos estreptococos mutans, apesar de fazerem um único bochecho diário com doses de $6 \mathrm{mg}$ de clorexidina e de $2,5 \mathrm{mg}$ de fluoreto de sódio. É relevante enfocar-se a segunda contagem, mostrando que 24 horas após o primeiro bochecho, a solução já produziu efeito muito bom nessas crianças, que no início apresentaram contagens aproximadas de 500.000 UFC. As demais registraram baixos níveis, o que provavelmente contribuiu para a não visualização do potencial antimicrobiano do Duplak. É importante relatar que essas crianças que tiveram as contagens 
decrescidas não apresentavam dentes permanentes em erupção. Destaca-se esse fato, pois MEURMAN et al. $^{75}$ relataram que terceiros molares parcialmente irrompidos podem contribuir para escores relativamente altos de estreptococos mutans na saliva e também se constituírem em reservatórios importantes e isso poderia ser verdadeiro também para a erupção de outros dentes. Houve também, nessas crianças, redução satisfatória no índice de placa.

As informações que existem sobre a propriedade antiplaca e antimicrobiana dessa combinação de clorexidina e flúor, são advindas de trabalhos com metodologias diferentes o que torna difícil maiores comparações com este estudo.

Os resultados em animais de laboratório ${ }^{15,71}$ têm revelado ação anticariogênica e antiplaca dessas substâncias, mesmo com baixa concentração de flúor. Interessantemente, cáries de fossas e fissura foram reduzidas com essa combinação ${ }^{71}$.

Em pesquisa desenvolvida por SPETS-HAPPONEN et al. ${ }^{99}$ não se evidenciou ação sobre as contagens de estreptococos mutans quando da realização de bochechos por 5 dias com intervalos de 3 semanas, durante 2 anos e 9 meses, com associação de clorexidina e flúor, inclusive após uma semana do esquema empregado. Pelos resultados, os autores concluíram que esse esquema não poderia ser recomendado se comparado com o de outros trabalhos de uso prolongado e diário da solução de clorexidina e flúor, apesar de detectarem uma tendência, embora não significante, para menor incidência de cárie nas crianças que utilizaram essa combinação em comparação com o uso da clorexidina sozinha. Entretanto, em outro 
trabalho, os mesmos autores ${ }^{98}$ empregando a mesma associação, somente que com o dobro de volume $(10 \mathrm{ml}$ contra $5 \mathrm{ml}$ ) obtiveram um decréscimo de $75 \%$ na contagem de estreptococos mutans na saliva de crianças, após 3 dias de bochechos e da ordem de 45\% depois de uma semana do último bochecho.

A combinação de clorexidina e flúor tem sido estudada com o intuito de melhorar os efeitos sobre a placa e cárie dos componentes individuais. Trabalhos clínicos e "in vitro", têm mostrado efetividade da associação, particularmente contra estreptococos mutans ${ }^{3,50,66,98,103}$. Assim, EMILSON ${ }^{28}$, após verificar que o tratamento com gel de clorexidina suplementado com aplicações de flúor prolongou o tempo de supressão dos estreptococos mutans mais que o tratamento com a clorexidina sozinha, apresentou uma provável explicação para o fato: o íon flúor, sendo pequeno, poderia alcançar e interferir nas atividades metabólicas dos estreptococos mutans sobreviventes nos sítios de retenção e em lesões incipientes de esmalte e, assim, contribuir para o retardamento do seu reaparecimento. Outra possibilidade seria a diminuição da vantagem ecológica que essa bactéria possui nos sítios de retenção, com pH baixo, uma vez que sua produção de ácido foi inibida em maior extensão pela combinação da clorexidina com o flúor, do que pelas substâncias isoladas ${ }^{73}$. TWETMAN; PETERSON ${ }^{103}$, empregando verniz com associação, também mostraram melhor ação sobre os estreptococos mutans quando essas substâncias estavam combinadas, destacando que independente do método, há uma provável ação sinérgica e, especificamente no seu caso, os autores relatam que pode ter existido uma melhor retenção do verniz, verificada clinicamente. 
O mecanismo inibitório da associação contra S. mutans, "in vitro", parece dever-se a alterações nas funções associadas à membrana celular, como o metabolismo de potássio, fósforo e fosfato e transporte de açúcar pela força próton-motriz que dirige o processo, assim como à inibição da produção de ácido ${ }^{66,67,73}$. A combinação também levou à maior liberação inicial de fosfatos bacterianos e re-endurecimento do esmalte pré-amolecido, do que cada um dos componentes sozinhos ${ }^{67}$.

Com relação ao grupo III, verifica-se na Tabela 18, que apenas a criança 13, que apresentava 1.000 .000 de UFC (Unidades Formadoras de Colônias) de estreptococos mutans por $\mathrm{ml}$ de saliva, foi beneficiada com o bochecho de digluconato de clorexidina 0,2\%. Algumas crianças, nesse grupo, apresentaram um aumento nesse número, na última contagem (crianças 2, 3, 6 e 9). Com exceção das crianças 3 e 6, esse aumento não representava, provavelmente prejuízo clínico para o paciente. Na criança 3, apesar do aumento, o I.P.F. foi reduzido. Já na criança 6, não houve diminuição satisfatória do I.P.F. em relação ao I.P.I. Também é importante evidenciar que os pré-molares dessas crianças e o segundo molar permanente da criança 6, estavam irrompendo, o que pode ter favorecido, como citado anteriormente para o grupo II, escores elevados nas contagens de estreptococos mutans, pois esses dentes podem ter funcionado como reservatórios importantes dessas bactérias ${ }^{52,75}$. A persistência de altos níveis de estreptococos mutans em localização anatômica específica e nichos da dentição, após procedimentos restauradores, raspagem e profilaxia profissional com ou sem aplicação tópica de flúor, terapia antimicrobiana e procedimentos de higiene bucal, foi verificada em outras investigações ${ }^{29,52,99}$. 
Os resultados deste estudo não foram semelhantes aos de ZICKERT; EMILSON; KRASSE ${ }^{110}$ que também trabalharam com crianças, porém fizeram tratamento intensivo com gel contendo clorexidina 1,0\% nos pacientes com elevadas contagens de estreptococos mutans, nem aos de HILDEBRANDT ${ }^{44}$, que utilizando verniz com clorexidina encontrou redução nas contagens desses microrganismos, nos pacientes que apresentavam valores maiores ou iguais a $10^{5}$, ou ainda, os de SCHAEKEN et al. ${ }^{92}$ que, em adultos, conseguiram a supressão dos estreptococos mutans com a associação de gel de clorexidina $5 \%$ e bochechos de clorexidina $0,2 \%$.

Aqui se confirma que a clorexidina apresenta indicação específica para suprimir estreptococos do grupo mutans, de cavidades bucais colonizadas com altos níveis desses microrganismos ${ }^{28}$. Daí, a significante redução no incremento de cárie, em crianças, quando o retratamento com clorexidina é realizado na re-infecção por essas bactérias em níveis de pré-tratamento ${ }^{110}$. Considera-se que a baixa atividade de cárie de crianças tratadas com clorexidina poderia ser o aumento da possibilidade de remineralização pela saliva durante os períodos de menor produção ácida pela bactéria ${ }^{28}$.

Outros estudos "in vivo", evidenciaram a ação da clorexidina em várias concentrações e formas de aplicação sobre a contagem de microrganismos salivares $3,27,28,44,48,50,77,78,87,92,93$. Dentre as várias formas de aplicação, a maior duração na redução dos estreptococos mutans é vista com o uso dos vernizes de clorexidina, seguido do gel e depois dos bochechos, especialmente quando sítios retentivos estão presentes na dentição ${ }^{28}$. Observa-se que a dose diária 
dos métodos mais eficientes é maior que a empregada no grupo III, que foi de $10 \mathrm{mg} /$ dia, visto a necessidade de adaptação do regime para aplicação em crianças dessa faixa etária ${ }^{10,11,109}$.

Todavia, a solução a $0,2 \%$, no volume de $10 \mathrm{ml}$ reduz as contagens bacterianas salivares até 7 horas após o bochecho $2,27,48,77,87$. De outro lado, seu emprego 4 vezes ao dia em crianças submetidas a tratamento quimioterápico causou redução efetiva nos níveis de estreptococos mutans salivares ${ }^{100}$. Esse dado é importante, pois os autores discutem que $25 \%$ a $54 \%$ dos casos de septicemia, em pacientes que recebem esse tratamento, parecem originar-se de infecção bucal. Assim, o uso profilático da clorexidina é um importante fator na diminuição da infeç̧ão bucal, devendo ser usado de rotina nas crianças que recebem esse tipo de tratamento ${ }^{100}$. Observa-se a importância não apenas da dose como no número dos bochechos para resultado realmente eficiente. Em voluntários com idades entre 16 e 84 anos submetidos a radioterapia, JOYSTON-BECHAL et al. ${ }^{50}$ não conseguiram reduzir os estreptococos mutans com dois bochechos diários tendo que recorrer ao gel para alguns pacientes. Outro fato a ser levado em consideração é o sabor amargo e desagradável que foi atribuído à essa substância pela maioria das crianças (Tabela 14 e figura 9), que pode ter contribuído para variações no uso da clorexidina aplicada em casa, comprometendo, assim, seu efeito.

Neste trabalho, a manutenção do número de microrganismos (Tabela 18), nas crianças, pode estar indicando a persistência de hábitos dietéticos e de higiene bucal inadequados, uma vez que as crianças não foram orientadas a respeito. Especialmente na 
criança 6 observa-se que o índice de placa não foi reduzido de forma eficiente enquanto na criança 2 ocorreu um aumento do mesmo. Ambas apresentavam hábitos de ingestão freqüente de doces. A mesma possibilidade foi levantada por HILDEBRANDT ${ }^{44}$ em seu estudo.

Do mesmo modo que no grupo II, no grupo III também não se observou atividade antimicrobiana uma semana após o último bochecho, ou seja, um efeito residual. No estudo longitudinal de SCHIÖTT, BRINNER; LÖE ${ }^{93}$, observou-se o efeito da clorexidina, reduzindo o número de indivíduos dos quais os estreptococos mutans podiam ser isolados. Outros trabalhos registraram esse efeito do bochecho com clorexidina, em diminuir e manter baixos os níveis de estreptococos mutans ${ }^{19,27,42,48,87}$.

Como não se pôde detectar ação sobre os níveis de estreptococos mutans, pelas baixas contagens iniciais, outras pesquisas são de interesse para verificar o que resultaria do emprego desse regime, em crianças que apresentassem elevadas contagens iniciais dessas bactérias.

Com relação ao grupo IV, 2 crianças apresentaram maiores contagens iniciais de estreptococos mutans na saliva e se mantiveram, como observado na Tabela 19 (crianças 67 e 69). Uma criança apresentou aumento considerável (criança 79) e as demais, em todas as etapas, mostraram valores baixos. Observa-se que o I.P.F. desses participantes também não apresentou redução favorável. 0 aumento ocorrido na criança 79 bem poderia ser atribuído aos hábitos dietéticos, assim como ao estado de erupção parcial dos incisivos laterais inferiores permanentes. 
Trabalhos laboratoriais mostraram a ação do esteviosídeo sobre os microrganismos bucais. YABU et al. ${ }^{107}$, verificaram uma limitação do crescimento bacteriano em meio com esteviosídeo e glicose e DAS et al. ${ }^{22}$ encontraram uma menor contagem de S. sobrinus, em animais que tiveram adicionados em sua dieta, esteviosídeo e rebaudiosídeo A 0.5\%, os quais não foram cariogênicos nem produziram efeitos adversos. BERRY; HENRY ${ }^{9}$ demonstraram que diferentes cepas do grupo mutans produziram menos ácido e cresciam menos em presença de esteviosídeo que na de carboidratos comuns, enquanto CHEDID ${ }^{17}$ observou que duas cepas de estreptococos mutans foram incapazes de fermentar ou formar placa "in vitro", frente ao esteviosídeo. ROSSONI ${ }^{90}$ relatou em seu trabalho que o esteviosídeo $0,2 \%$ propiciou baixo nível de crescimento dessas bactérias. A ação antibacteriana do esteviosídeo tem sido relacionada à sua influência sobre a enzima glicosiltransferas ${ }^{51}$ e à presença de taninos ${ }^{82,83}$.

São raros os trabalhos encontrados na literatura com essa substância; e também, como já explicado no item de análise clínica, o não uso do conservante na solução pode ter colaborado com a sua baixa atuação. Por isso, mais investigações devem ser elaboradas, com o intuito de verificar a ação da mesma, especificamente em associação ao fluoreto de sódio acidulado sobre os estreptococos mutans, já que existem trabalhos mostrando alguma inibição sobre a placa dentária ${ }^{11,109}$ e cárie dentária ${ }^{55}$.

As baixas contagens de estreptococos mutans apresentadas pela maioria das crianças no início do estudo, podem ser a explicação para a falta de diferença significante entre as três etapas para 
todos os tratamentos (Tabela 20). Estes valores encontrados no início, para a maioria das crianças, foram atribuídos à presença, em uma das escolas, de um programa de prevenção, embora que suspenso 3 meses antes, bem como aos hábitos dietéticos e erupção dos dentes permanentes. Outro fato é que as crianças apresentavam baixa experiência de cárie ou as cavidades já estavam restauradas.

Sabe-se que a experiência passada de cárie indica a existência de sítios retentivos na dentição, importantes nichos para os estreptococos mutans. KRASSE ${ }^{58}$ considera que o risco de cárie inicia-se quando o paciente apresenta mais de 100.000 UFC de estreptococos mutans, por $\mathrm{ml}$ de saliva, atingindo o nível de alto risco quando esse valor chega a 1.000.000 UFC por $\mathrm{ml}$ de saliva. Assim, pode-se atribuir a algumas das crianças que apresentavam maiores contagens iniciais, 0 fato de terem experiência passada de cárie nas superfícies oclusais e/ou especialmente nas áreas interproximais.

A indicação do uso de antimicrobianos é precisa. Em pacientes com alta atividade de cárie e altas contagens de estreptococos mutans, a clorexidina pode ser empregada como um adjunto de outras medidas preventivas, utilizada com o intuito de reduzir o acúmulo de placa dessas bactérias ${ }^{14,28}$.

O presente trabalho mostra que o emprego de soluções contendo clorexidina, que visa a diminuição da placa como um todo e dos estreptococos mutans, não é efetiva para o controle dos últimos se o número não for alto, pois, como observado, as maiores reduções têm sido obtidas em pacientes que apresentam essa característica ${ }^{110}$. 
A associação da clorexidina com o fluoreto de sódio tem o mérito de acrescentar o flúor em baixa concentração, que além de reduzir a acidogenicidade do grupo mutans, favorece a remineralização dos dentes.

O esteviosídeo não apresentou redução nas contagens de estreptococos mutans neste trabalho, porém é uma substância que ainda merece atenção para novas investigações, visto apresentar algum efeito sobre o metabolismo bacteriano $0^{9,22,90,107}$ e da placa dentária ${ }^{17,84}$, bem como na redução da cárie ${ }^{20,55,79}$ e acúmulo de placa bacteriana ${ }^{11,96,109}$.

A escolha de uma substância antimicrobiana, para utilização como coadjuvante da higiene bucal da criança, quando necessário, é muito importante. Esse paciente geralmente apresenta dificuldade em realizar sua higiene bucal habitual, apesar da maior facilidade de aprendizagem. É considerado um paciente de risco, por suas características de crescimento e desenvolvimento físico e psicológico além de apresentar características bucais especiais como, dentes em fase de erupção e portanto mais susceptíveis, por não terem sofrido a maturação pós-eruptiva. 


\section{7 - CONCLUSÕES}




\section{7- CONCLUSÕES}

De acordo com os resultados obtidos neste estudo e a análise estatística aplicada nos mesmos, sobre o efeito de bochechos diários com água deionizada mentolada, gluconato de clorexidina $0,12 \%$ associado ao fluoreto de sódio $0,05 \%$, digluconato de clorexidina $0,2 \%$ e esteviosídeo 0,5\% associado ao fluoreto de sódio 0,05\% pH 3,4, em crianças, pode-se concluir que:

7.1 - Em relação à capacidade de inibição do acúmulo de placa bacteriana:

7.1.1 - As soluções dos grupo II e III reduziram o acúmulo de placa dentária, de forma estatisticamente significante, sendo de $26,75 \%$ para o gluconato de clorexidina $0,12 \%$ associado ao fluoreto de sódio $0,05 \%$ (grupo II) e de $41,20 \%$ para o digluconato de clorexidina $0,2 \%$ (grupo III);

7.1.2 - Não houve diferença estatisticamente significante entre o esteviosídeo 0,5\% associado ao fluoreto de sódio 0,05\% pH 3,4 e a solução controle, com relação ao acúmulo de placa;

7.1.3 - Quanto às faces dentárias, a redução do acúmulo de placa foi em ordem decrescente de vestibular, proximal e lingual, para 
o grupo III, de lingual, vestibular e proximal para o grupo IV e de vestibular, proximal e lingual para o grupo II, não havendo diferença estatisticamente significante para este último grupo;

7.2 - Quanto a aceitação das soluções pelas crianças a solução de digluconato de clorexidina $0,2 \%$ foi a menos aceita, com $79,07 \%$ dos participantes considerando-a ruim e mais ou menos e $53,49 \%$ relatando sabor amargo;

7.3 - No que se refere aos efeitos colaterais, a pigmentação dentária suave foi observada em 14,89\% das crianças do grupo do gluconato de clorexidina $0,12 \%$ associado ao fluoreto de sódio $0,05 \%$ e em $27,91 \%$ nas do grupo do digluconato de clorexidina $0,2 \%$, muitas vezes localizada em um único elemento dentário, a maioria em incisivos;

7.4 - As contagens de estreptococos mutans não evidenciaram diferença estatisticamente significante entre as 3 coletas de saliva, nos 4 grupos de estudo, sendo que o nível inicial dessas bactérias já era baixo. 


\section{REFERÊNCIAS BIBLIOGRÁFICAS}




\section{REFERÊNCIAS BIBLIOGRÁFICAS*}

1 - ADOÇANTES naturais da stévia: dados essenciais. Maringá, Ingá Stévia Industrial, 1991. 29 p. / Dossiê Técnico Comercial /

2 - ADDY, M.; JENKINS, S.; NEWCOMBE, R. The effect of triclosan, stannous fluoride and chlorhexidine products on: (I) plaque regrowth over a 4-day period. J. clin. Periodont., v. 17, n. 10, p. 693-7, Nov. 1990.

3 - ADDY, M.; JENKINS, S.; NEWCOMBE, R. The effect of some chlorhexidine-containing mouthrinses on salivary bacterial counts. J. clin. Periodont., v. 18, n. 2, p. 90-93, Feb. 1991.

4 - ADDY et al. Comparison of two commercially available chlorhexidine mouthrinses: I- Stainning and antimicrobial effects "in vitro". Clin. Prev. Dent., v. 11, n. 5. Sept-Oct., 1989.

5 - ADDY et al. The comparative tea stainig potential of phenolic, chlorhexidine and anti-adhesive mouthrinses. J. clin. Periodont., v.22, p. 923-28, 1995.

\footnotetext{
"Normas recomendadas para uso no âmbito da Universidade de São Paulo, com base no documento "Referências Bibliográficas: exemplos", emanado do Conselho Supervisor do Sistema Integrado de Biblioteca da USP, em reunião de 20 de fevereiro de 1990.
} 
6 - ASIKAINEN, S. et al. Plaque-inhibiting effect of two flavored chlorhexidine mounthrinses. J. clin Periodont., v. 8, n. 3, p. 139-43, Mar. 1981.

7 - AXELSSON, P.; LINDHE, J. Efficacy of mouthrinse in inhibiting denta plaque and gingivites in man. J. clin Periodont., v. 14, n. 4, p. 205-12, Apr. 1987.

8 - $\quad$ BELLINI, H. T. et al. Uso da clorexidina no controle da placa e da gengivite (estudo comparativo da aplicação tópica e em forma de bochechos). Rev. Ass. paul. cirurg. Dent., v. 34, n. 4, p. 276-82, jul./ago. 1980.

9 - BERRY, C. W.; HENRY, C. A. Effect of Stevioside on the growth and production of Streptococcus mutans. J. dent. Res., v. 60, p.430, Mar. 1981. Special issue A/Abstract n.480/.

10 - BIJELLA, M. F. T. B. et al. Avaliação do efeito inibidor de bochechos diários com fluoreto de sódio neutro e acidulado a 0,05\% sobre o metabolismo da placa dentária humana (fermentação e síntese de polissacarídeos extracelulares). CECADE News, v. 2, n. 2, p. 1-19, mai./ago. 1994.

11 - BIJELLA, M. F. B. et al. Influência de soluções para bochechos sobre a placa bacteriana, em crianças. In: REUNIÃo CIENTÍFICA DA SOCIEDADE BRASILEIRA DE PESQUISAS ODONTOLÓGICAS, 14. Águas de São Pedro, 1997. Anais. São Paulo, SBPqO, 1997. /Poster 093/ 
12 - BINNEY, A.; ADDY, M.; NEWCOMBE, R. G. The effect of a number of commercial mouthrinses compared with toothpaste on plaque regrowth. J. Periodont., v. 63 , n. 10, p. 839-42, Oct. 1992.

13 - BONESVOLL, P. Retention and plaque-inhibiting effect in man of chlorhexidine after multiple mouth rinses and retention and realie of chlorhexidine after toothbrushing with a chlorhexidine gel. Arch. oral Biol., v. 13, n. 4, p. 295-300, Apr. 1978.

14 - BOWDEN, G.H. Mutans streptococci caries and chlorhexidine. J. Canad. dent. Ass., v. 62, n.9, p. 700-706, Sept. 1996.

15 - BRAYER, L.; GEDALIA, J.; GOVER, A. Clorexidine and fluoride in prevention of plaque and caries in hamters. J. dent. Res., $\mathrm{v}$. 56, n. 2, July-Dec., p. 1365-8, 1977.

16 - BRECX, M. et al. Long-term effects of Meridol and chlorhexidine mouthrinses on plaque, gingivitis, stainning and bacterial vitality. J. dent. Res., v. 72, n. 8. p. 1194-97, Aug. 1993.

17 - CHEDID, S. J. Efeito dos adoçantes esteviosídeo, aspartame, xilitol e sacarina sobre a fermentação e síntese de polissacarídeos extra-celulares insolúveis pelo Streptococcus mutans GS-5 e LM-7 e pela placa dentária "in vitro". São Paulo, 1990. 105 p. Dissertação (Mestrado)- Faculdade de Odontologia de São Paulo, Universidade de São Paulo. 
18 - CIANCIO, S. G. Drugs in dentistry. Dent. Manag., v. 124, p. 5860, May 1986.

19 - COLLAERT, B. et al. Rinsing with delmopinol $0,2 \%$ and chlorhexidine 0,2\%: Short-term effect on salivary microbiology, plaque, and gingivitis. J. Periodont., v. 63, n. 7, July 1992.

20 - CORRÊA, P.Z.; ROSSONI, E.; MALTZ, M. O efeito de adoçante comercial a base de esteviosídeo em um modelo intra oral: IAspectos macrocópicos do esmalte. REUNIÃo CIENTÍFICA DA SOCIEDADE BRASILEIRA DE PESQUISAS ODONTOLóGICAS, 12., Águas de São Pedro, 1995. /Poster 233/

21 - CUMMING, B. R.; LÖE, H. Optimal dosage and method of delivering chlorhexidine solutions for the inhibition of dental plaque. J. Periodont. Res., v. 8, n. 2, p. 57-62, Mar./Apr. 1973.

22 - DAS, S. et al. Evaluation of th cariogenic potential of the intense natural sweeteners stevioside nd rebaudioside A. Caries Res., v. 26, n. 5, p. 363-6, Sept./Oct. 1992.

23 - DAVIES, A. The mode of action of chlorhexidine. J. Periodont. Res., v. 8, p. 68, 1973. Supplement 12. 
24 - DOLLES, O. K.; GJERMO, P. Caries increment and gingival status during two years of chlorhexidine and fluoride containing dentifrices. Scand. J. dent. Res., v.88, p. 22-7, 1980.

25 - DUBOIS, G. E.; STEPHESON, R. A. Diterpenoid sweeteners and sensory evaluation of stevioside analogues with improved organoleptic. J. med. Chem., v. 28, p. 93-8, Jan. 1985.

26 - EATON, K. A. et al. The effects of a 0,12\% chlorhexidine digluconate containing mouthrinse versus a placebo on plaque and gingival inflammation over a 3 - month period. J. clin. Periodont., v. 24, n. 3, p. 189-197, 1997.

27 - ELWORTHY, A. et al. The substantivity of a number of oral hygiene products determined by the duration of effects on salivary bacteria. J. Periodont., v. 67 , n. 6, p. 572-76, Jun. 1996.

28 - EMILSON, C. G. Potential efficacy of chlorhexidine against mutans streptococci and human dental caries. J. dent. Res., v. 73, n. 3, p. 682-91, Mar. 1994.

29 - EMILSON, C. G.; LINDQUIST,B. Importance of infection level of mutans streptococci for recolonization of teeth after cholrhexidine treatment. Oral Microbiol. Immunol., v. 3, p.64-67, 1988. 
30 - ETEMADZADEH, $\mathrm{H}$. et al. Effect of plaque growth and salivary micro-organisms of amine fluoride-stannous fluoride and chlorhexidine-containing mouthrinses. J. clin. Periodont., v. 16, n.3, p. 175-8, Mar. 1989.

31 - FEIST, H. S.; MICHELI, G. de; SARIAN, R. Clorexidina - prós e contras. Rev. Ass. paul. cirurg. Dent., v. 43, n. 1, jan./fev. 1989.

32 - FRANCIS, J. R.; HUNTER, B.; ADDY, M. A comparison of three delivery methods of chlorhexidine in handicapped children. I. Effects on plaque, gingivitis, and toothstaining. J. Periodont., v. 58, n. 7, p. 451-5, July 1987.

33- GIBBONS, R. J.; VAN HOUTE, I. On the formation of dental plaque. J. Periodont., v. 44, n. 6, p. 347-60, June 1973.

34- GJERMO, P. Agentes mecanicos y quimicos en el control de la placa. Rev. asoc. odont. Argent., v. 68, n. 5, p. 311-5, Set. 1980.

35 - GJERMO, P. Chlorhexidine and related compounds. J. dent. Res., v. 68, p. 1602-608, May/Dec. 1989.

36 - GJERMO,P.; ROLLA, G.; ÅRSKAUG, L. Effect of dental plaque formation and some "in vitro" properties of 12 bisguanides. J. Periodont. Res., v. 8, p. 81-8, 1973. Supplement 12. 
37 - GJERMO, P. et al.. Influence of variation of pH of chlorhexidine mouth rinses on oral retention and plaque-inhibiting effect. Caries. Res., v.9, n.1, p. 74-82, Jan./Feb. 1975.

38 - GOTO,A.; CLEMENTE, E. Influência do rebauduosídeo A na solubilidade e no sabor do esteviosídeo. Cienc. tecnol. Aliment., v. 18, n. 1, p. 3-6, jan./abr. 1998.

39- GROSSMAN, E. et al. A clinical comparison of antibacterial mouthrinses: effects of chlorhexidine, phenolics, and sanguinarine on dental plaque and gingivitis. J. Periodont., v. 60, n. 8, p. 435-40, Aug. 1989.

40 - HANSON, J. R.; OLIVEIRA, B. H. Stevioside and related sweet diterpenoic glycosides. Nat. prod. Report., v. 10, n. 3, p. 301-9, June 1993.

41- HASE, J. C. et al. Plaque formation and gingivitis after mouthrinsing with $0,2 \%$ delmopinol hydrochloride, 0,2\% chlorhexidine digluconate and placebo for 4 weeks, following an initial professional tooth cleaning. J. clin. Periodont., $v$. 22, n. 7, p. 533-9, July 1995.

42 - HASE, J. C. et al. 6 month use of 0,2\% delmopinol hydrochloride in comparison with $0,2 \%$ chlorexidine digluconate and placebo. (II) Effect on plaque and salivary microflora. J. clin. Periodont., v. 25, n. 11, p. 841-49, Nov. (part I), 1998. 
43 - HENNESSEY, T. D. Antibacterial properties of Hibitante. J. clin. Periodont., v. 4, n. 5, p. 36, May 1977.

44 - HILDEBRANDT, G. H. Effect of repeated treatment with sustainedrelease chlorhexidine mouthguards on salivary levels of mutans streptococci. Caries Res., v. 30, n. 6, p. 445-53, 1996.

45 - IKEDA, T. Sugar substitutes: reasons and indications for their use. Int. dent. J., v. 32, n. 1, p. 33-42, 1982.

46 - JENKINS, S.; ADDY, M.; WADE, W. The mechanism of action of chlorhexidine. A study of plaque growt on enamel inserts "in vivo". J. clin Periodont., v. 15, n. 7, p. 415-24, July 1988

47 - JENKINS, S.; ADDY, M.; NEWCOMBE, R. Evaluation of a mouthrinse containing clhorhexidine and fluoride as na adjunct to oral hygiene. J. clin. Periodont., v. 20, n. 20-5, 1993.

48 - JENKINS, G. N. et al. The magnitude and duration of the effects of some mouthrinse products on salivary bacterial counts. J. clin. Periodont., v. 21, n. 6, p. 397-401, July 1994.

49 - JOYSTON-BECHAL, S.; HERNAMAN, N. The effect of a mouthrinse containing chlorhexidine and fluoride on plaque and gingival bleeding. J. clin. Periodont., v. 20, n. 1, p. 49-53, 1993. 
50 - JOYSTON-BECHAL, S. et al. Caries incidence, mutans streptococci and lactobacilli in irradiated patients during a 12 month preventive program using chlorexidine and fluoride. Caries Res., v. 26, n. 5, p. 384-390, 1992.

51 - KASKHET, et al. In vitro inhibition of glucosyltransferase from the dental plaque bacterium streptococcus mutans by common beverages and food extracts. Arch. oral Biol., v. 30, $\mathrm{n}$. 11/12, p. 821-6, July/Dec. 1985.

52 - KEENE, H. J. et al. Primary reservois of Streptococcus mutans and their relationship to caries experience in adults with good oral hygiene. Oral Microbiol. Immunol., v. 5, p. 19-23, 1990.

53 - KIDD, E. H. M. Role of chlorhexidine in the management of dental caries. Int. dent. J., v. 41, n. 5, p. 279-86, Oct. 1991.

54 - KIYONO, R. H. et al. Grau de sensibilidade de anaeróbios e antimicrobianos. Rev. Ass. paul. cirurg. Dent., v. 47, n. 1, jan./fev. 1993.

55 - KLEBER, C. J. Rat dental caries investigation of steviosode natural sweetener. Benton, Sun Up Foods, 1990. /Final report/

56 - KNEIST, S.; HEINRICH-WELTZEIN, R; STÖSSER, G. A comparison between commercial kits and conventional methods for the enumeration of mutans streptococci. Caries Res., v. 30, n. 4, p. 286, July-Aug. 1996. 
57 - KNEIST, S. et al. Correlation between numbers of streptococcus mutans in plaque and saliva. Caries Res., v. 32, n. 4, p. 287 (n 60), July-Aug. 1998.

58 - KRASSE, B. Risco de Cárie: guia prático para controle e acessoramento. São Paulo. Quintessence Editora Ltda, 2 ed, 1988, 113p.

59 - LACAZ NETTO, R. et al.. Controle da placa dentária. Rev. gaúcha Odont., v. 35, n. 4, p. 259-63, jul./ago. 1987.

60 - LANG, N. P.; BRECX, M. C. Chlorhexidine digluconate - an agent for chemical plaque control and prevention of gingival inflamation. J. Periodont. Res., v. 21, p. 74-89, 1986. Supplement n. 16.

61 - LANG, N. P. et al. Effects of supervised chlorhexidine mouthrinses in children. A longitudinal clinical trial. J. Periodont. Res., v. 17, n. 1 , p. 101-11, Jan. 1982

62 - LÖE, H. The gingival index, the plaque index and the retention index systems. J. Periodont., v. 38, p. 610-6, Nov./ Dec. 1967.

63 - LÖE, H.; SCHIÖTT, C. R. The effect of mouthrinses and topical application of chlorhexidine on the development of dental plaque and gingivitis in man. J. Periodont. Res., v. 5, n. 2, p. 79-83, Mar. 1970. 
64 - LÖE, H.; VON DER FEHR, F. R.; SCHIÖTT, C. R. Inhibition of experimental caries by plaque prevention. The effect of chlorhexidine mouthrinses. Scand. J. dent. Res., v. 80, p. 19, 1972.

65 - LÖE, H. et al. Two years oral use of chlorhexidine in man. I. General design and clinical effects. J. Periodont. Res., v. 11, n. 3, p. 135-44, May 1976.

66 - LUOMA, H. The effects of chlorhexidine and fluoride combinations on the potassium sodium and phosphorus content and acid production of cariogenic streptococci. Arch. oral Biol., v. 17, n.2, p. 1431-7, Oct. 1972.

67 - LUOMA, H. Participation of phosphate of bacterial origin in phosphate exchange and reharding of enamel and modifications by fluoride, chlorhexidine and propanol. Caries Res., v. 9, v.3, p. 211-23, 1975.

68 - LUOMA, H. Chlorhexidine solutions, gels and varnishes in caries prevention. Proc. Fin. dent. Soc., v. 88, n. 3-4, p. 147-52, July 1992.

69 - LUOMA, $\mathrm{H}$. et al. Reduction of enamel solubility and plaque development with clhorhexidine-fluoride solutions. Scand. J. dent. Res., v. 81, p. 523-27, Aug. 1973. 
70 - LUOMA, $\mathrm{H}$. et al. A simultaneous reduction of caries and gingivites in a group of schoolchildren receiving chlorhexidine-fluoride applications. Results after 2 years. Caries Res., v. 12, n. 5, p. 290-98, 1978.

71 - LUOMA, $\mathrm{H}$. et al. Caries reduction in rats by clhorexidina-fluoride applications without or with Sr. and Zn. J. dent. Res., v. 63, n. 1, Jan.-Jun., p. 316, 1984. Abst.1312.

72 - MARSH, P. D. Sugar, fluoride, pH and microbial homeostasis in dental plaque. Proc. Fin. dent. Soc., v. 87, p. 515-25, Jan./Mar. 1991.

73 - McDERMID, A. S. et al. Additive inhibitory effects of combinations of fluoride and chlorhexidine on acid production by Streptococcus mutans and Streptococcus sanguis. Caries Res., v. 19, n. 1, p. 64-71, 1985.

74 - MENDIETA, C. et al. Comparison of chlorhexidine mouthwashes on plaque regrowth in vivo and dietary staining in vitro. $\mathbf{J}$. clin. Periodont., v. 21, n. 4, p. 296-300, Apr. 1994.

75 - MEURMAN, J. $\mathrm{H}$. et al. Erupting third molars and salivary lactobacilli and Streptococcus mutans counts. Scand. J. dent. Res., v. 95, p. 832-836, 1987. 
76 - MORAN, J.; ADDY, M.; ROBERTS, S. A comparison of natural product, triclosan and chlorhexidine mouthrinses on 4-day plaque regrowth. J. clin. Periodont., v.19, n. 8, p. 578-582, Sept. 1992.

77 - MORAN, J. et al. The effect of oxidising mouthrinses compared with chlorhexidine on salivary bacterial counts and plaque regrowth. J. clin. Periodont., v. 22, n. 10, p. 750-55, Oct. 1995.

78 - NETUSCHIL, L. et al. Plaque bacteria counts and vitality during chlorhexidine, Meridol and Listerine mouthrinses. Eur. J. oral Sci., v. 103, n. 6, p. 355-61, Dec. 1995.

79 - OLIVEIRA, S. S. et al.. Influência do guaraná, da estévia rebaudiana Bertoni e do esteviosídeo na incidência de cárie em ratos. Estomat. Cult., v. 15, n. 3, p. 16-19, 1985.

80 - OVERHOLSER, C. D. et al. Comparative effects of 2 chemotherapeutic mouthrinses on the development of supra gingival dental plaque and gingivitis. J. clin. Periodont., v. 17, p. 575-9, 1990.

81 - OWENS, J. et al. A short-term study design to investigate the chemical plaque inhibitory properties of mouthrinses when used as adjuncts to toothpastes: applied to clhorexidine. J. clin. Peridont., v. 24, n. 10, p. 732-7, Oct. 1997. 
82 - PALENIK, J. C. et al. Effect of water soluble components derived from cocoa on plaque formation. J. dent. Res., v. 58, p. 1749, Apr./Dec. 1979.

83 - PAOLINO, V. J. Anti-caries activity of cocoa. J. dent. Res., v. 61, p. 389,1982 . Special Issue 71.

84 - PINHEIRO, C. E. et al. Efeito dos extratos de guaraná e de estévia rebaudiana Bertoni (folhas) e do esteviosídeo, sobre a fermentação e a síntese de polissacarídeos extracelulares insolúveis da placa bacteriana dentária. Rev. Odont. USP, v. 1, p. 9-13, out./ dez. 1987.

85 - RAMBERG, P. et al. The effects of antimicrobial mouthrinses on de novo plaque formation at sites with health and inflamed gingival. J. clin. Periodont., v. 23, n. 1, p. 7-11, Jan. 1996.

86 - RENTON-HARPER, P. et al. A comparison of chlorhexidine, cetylpyridinium chloride, triclosan, and C31G mouthrinse products for plaque inhibition. J. Periodont., V. 67, N. 5, P. 486-89, May 1996.

87 - ROBERT, W. R.; ADDY, M. Comparison of the "in vivo" and "in vitro" antibacterial properties of antiseptic mouthrinses containing chlorhexidine, alexidine, cetylpyridinium chloride and hexidine. J. clin. Periodont., v. 8, n. 3, p. 295-300, 1981. 
88 - ROSA, O. P. da S. Níveis salivares de estreptococos mutans e lactobacilos e susceptibilidade à cárie dentária. CECADE News, v. 2, n. 1, p. 15-26, jan./abr. 1994.

89 - ROSA, O. P. da; ROCHA, R. S. S. Clorexidina e cárie dentária. CECADE News, v. 1, n. 1/2, p. 1-24, jan./ago. 1993.

90 - ROSSONI, E. O efeito de adoçante comercial a base de esteviosídeo em um modelo intraoral: II- análise da microflora. In: REUNIÃO CIENTÍFICA DA SOCIEDADE BRASILEIRA DE PESQUISAS ODONTOLÓGICAS, 12. Águas de São Pedro, 1995. Anais. São Paulo, SBPqO, 1995. /Poster 205/

91 - SAKAGUCHI, M.; KAN, L. Enzimatic determination of stevioside on stevia rebaudiana. Ciência e Cultura, v. 34, n. 2, feb. 1982.

92 - SCHAEKEN, M. J. M. et al. Effects of highly concentrated stannous fluoride and chlorhexidine regimes on human dental plaque flora. J. dent Res., v. 65, n. 1, p. 57-61, Jan., 1986.

93 - SCHIÖTT, C. R.; BRINER, W. W.; LÖE, H. Two years oral use of chlorhexidine in man. II - The effect on the salivary bacterial flora. J. Periodont. Res., v. 11, n.--, p. 145-52, 1976.

94 - SEgRETO, V. A. et al. A comparison of mouthrinses containing two concentrations of clhorhexidine. J. Periodont. Res., v. 21, p. 23-32, 1986. Supplement 16. 
95 - SILVA, S. M.B. da. Efeito da aplicação tópica de agentes antimicrobianos sobre a inibição da placa dentária "in vivo", em crianças e seus efeitos colaterais e "in vitro" em ratos (Rattus novergicus, var-albinus). Bauru, 1991, 254 p. Tese (Doutorado)- Faculdade de Odontologia de Bauru, Universidade de São Paulo.

96 - SLAVUTZKY, S. M. B. de; SCARPINI, C. Ação anticariogênica dos bochechos com "Stévia". Rev. gaúcha Odont., v. 42, n. 5, p. 251-3, set./out. 1994.

97 - SMITH, R. G. et al. Comparative staining in vitro and plaque inhibitory properties in vivo of $0,12 \%$ and $0,2 \%$ chlorhexidine mouthrinses, J. clin. Periodont., v. 22, n. 9, p. 613-7, Sept. 1995.

98 - SPETS-HAPPONEN et al. Salivary Streptococcus mutans counts and gingivitis in children after rinsing with a chlorhexidinefluoride solution with and without strontium. Scand. J. dent. Res., v. 93, n. 4, p. 329-35, 1985.

99 - SPETS-HAPPONEN et al. Effects of clhorexidine-fluoride-stroncium rinsing program on caries, gingivites and some salivary bacteria among Finnish schoolchildren. Scand. J. dent. Res., v. 99, n. 2, april, p. 130-38, 1991.

100 - SULLIVAN, E. A. et al. Changes in the oral microflora during cytotoxic chemotherapy in children being treated for acut leukemia. Oral Surg., v. 76, n.2, Aug. 1993. 
101 - SVATUN, B. et al.. A comparison of the plaque-inhibiting effect of stannous fluoride and chlorhexidine. Acta odont. scand., v. 35, n. 5, p. 247-50, Oct. 1977.

102 - TONELLI, P.M.; HUME, W. R.; KENNEY, E. B. Chlorhexidine: A review of the literature. J. west. soc. Periodont., v. 31 , n. 1 , 1983.

103 - TWETMAN, S. e PETERSON, L. G. Efficacy of clhorexidine and clhorexidina-fluoride varnish mixture to decrease interdental levels of mutans streptococci. Caries Res., v. 31, n. 4, p. 361-65, Sept.-Oct. 1997.

104 - VELASCO VILLAVICENCIO, V. Avaliação do efeito inibidor de algumas soluções contendo fluoreto de sódio a $0,05 \%$ disponíveis no mercado e da influência do prétratamento com fluoreto estanoso, fluoreto de sódio, sobre o metabolismo da placa dentária humana. (Estudo "in vitro"). Bauru, 1989. 92p. Tese (Mestrado)Faculdade de Odontologia de Bauru- Universidade de São Paulo.

105 - WEI, S. H.; KANELLIS, M. J. Fluoride retention after sodium fluoride mouthrinsing by preschool children. J. Amer. dent. Assoc., v. 106, n. 5, p. 626-9, May 1983.

106 - XILI, L. et al.. Chronic oral toxicity and carcinogenicity study of stevioside in rats. Food chem. Toxicol., v. 30, n. 11, p. 95765, 1992. 
107 - YABU, M et al.. Studies on stevioside, natural sweetener. Effect on the growth of some oral microrganisms. Hiroshima Daigaku Shigaku Zasshi, v. 9, n. 1, p. 12-7, 1977.

108 - YAMAMOTO, T. et al. Gustatory reaction time to various sweeteners in human adults. Physiol. Behav., v. 35, p. 4115, 1984.

109 - ZANELA, N. L. M. Influência de bochechos com soluções de digluconato de clorexidina a $0,2 \%$, fluoreot de sódio a 0,05\% pH 3,4 e esteviosídeo 0,1\%, na inibição da placa dentária "in vivo", em crianças. Bauru, 1995. 109p. Tese (Mestrado)- Faculdade de Odontologia de BauruUniversidade de São Paulo.

110 - ZICKERT, I.; EMILSON, C. G.; KRASSE, B. Effect of caries preventive measures in children highly infected with the bacterium Streptococcus mutans. Arch. oral Biol., v. 27, n. 10, p. 861-8, July/Dec. 1982. 
ABSTRACT 


\section{ABSTRACT}

\section{INFLUENCE OF MOUTHRINSES WITH ANTIMICROBIAL SOLUTIONS ON THE DENTAL PLAQUE INHIBITION AND MUTANS STREPTOCOCCI COUNTS IN CHILDREN}

In children, the effect of mouthwashing was observed placebos solution made of mentholated deionized water (Group I), chlorhexidine gluconate $0.12 \%$ mixed sodium fluoride $0.05 \%$ (Group II), chlorhexidine digluconate $0.2 \%$ (Group III) and estevioside $0.5 \%$ mixed with sodium fluoride $0.05 \%$ ph 3.4 (Group IV), over the dental plaque accumulation and over the level of the salivary streptococcus mutans. In order to verify the effect on the plaque, the LÖE index was used and the saliva microbial count was taken through the CARITEST SM (Herpo Produtos Dentários LTDA). The sample consisted of 200 children between 7 and 11 years old, 50 per group. The accumulation of the dental plaque was evaluated at the beginning and at the end of the experiment. Twenty of these children were randomly selected from each group, in order to collect the saliva. This was done in 3 phases: initial (before the first mouthwashing), 24 hours after the first washing and a week after the last washing. In all groups, the children received professional profilaxy before the experiment and followed the routine of daily mouthwashing with $5 \mathrm{ml}$ of solution per minute, for 4 weeks. The results show an inhibition on the plaque accumulation of $2.81 \% ; 26.75 \% ; 41.2 \%$ and $5.91 \%$ for the Groups I, II, III and IV respectively. In relation to the 
dental faces, Groups II and III, show greater percentage reduction to the vestibular face, followed by the proximal and lingual, whereas, in Group II, there was no statistically significant difference between them and Group III. This difference occurred between the lingual and mesial faces. As to Group IV, this result was greater on the lingual face, and statistically different only on the distal face. The chlorhexidine digluconate $0.2 \%$ solution showed smaller acceptance by the children, and with the chlorhexidine gluconate $0.12 \%$ solution mixed with the sodium fluoride $0.05 \%$, it created smooth and similar dental pigmentation. In relation to the streptococcus mutans count, since the children showed low numbers of these microorganisms at the beginning of the experiment, they remained the same, producing no statistically significant difference between the counts. Therefore, it was concluded that the chlorhexidine gluconate $0.12 \%$ mixed with the sodium fluoride $0.05 \%$ and the chlorhexidine digluconate $0.2 \%$ solution were more affective in the control of the accumulation of the dental plaque in the method used. However, the second method showed a greater percentual reduction and a smaller acceptance related to the solution flavor. 